NYPL RESEARCH LIBRARIES

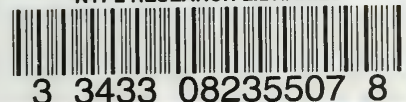

TMITIURIES

F OF THE 3

OLDHOMESTEAD

B) .H.H. LYMAN 


UPLICATE

EP 141932

N. Y.S. L.

Countin life-US - I.Y. - Lorrane. 




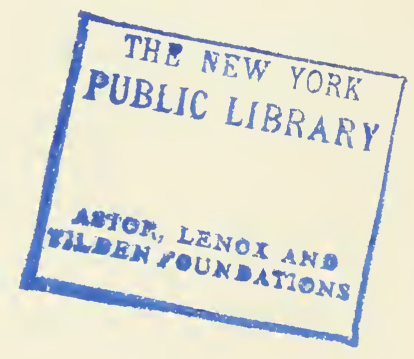




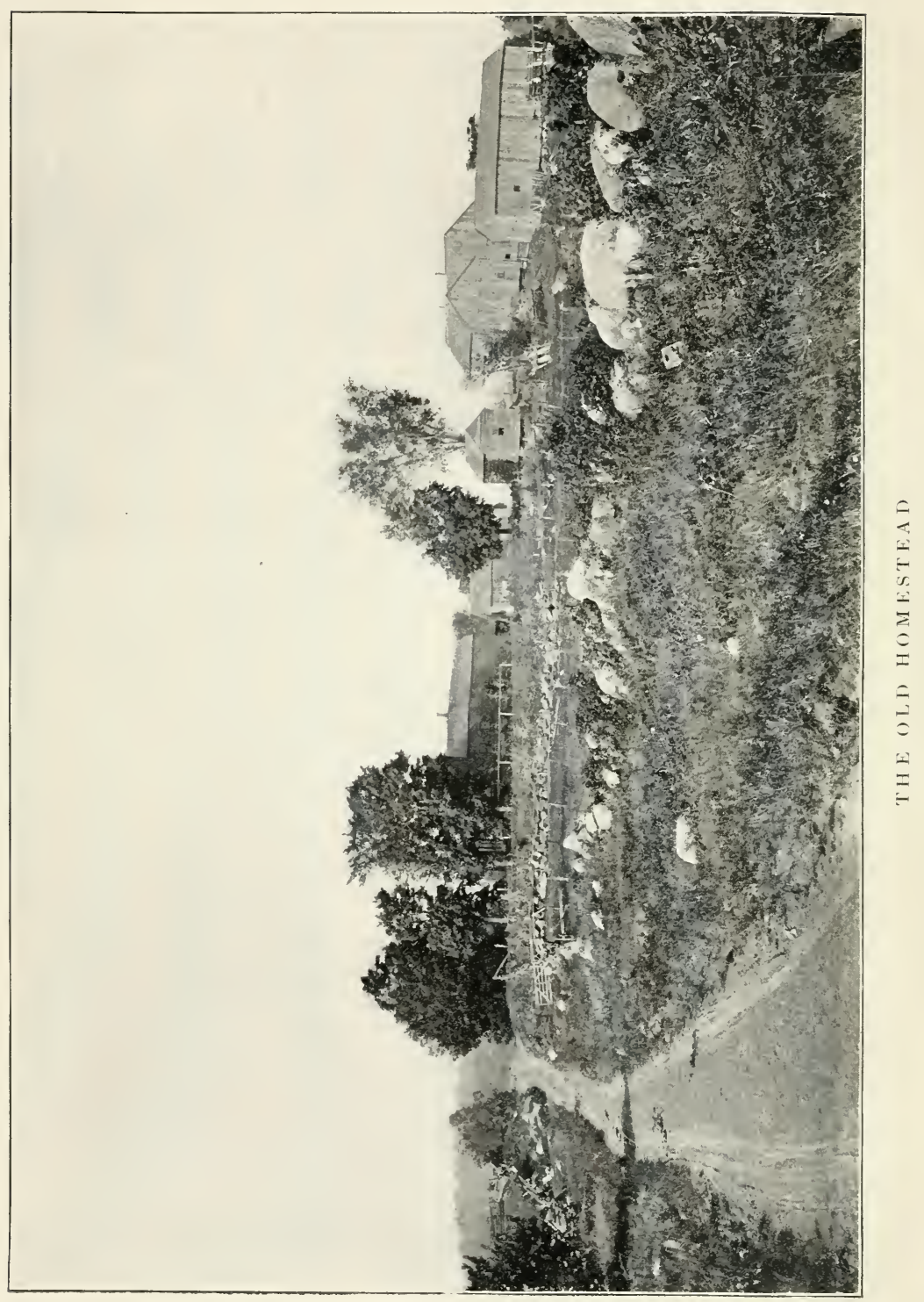




\title{
MEMORIES
}

\author{
OF THE
}

\section{OLD HOMESTEAD}

BY

H. H. LYMAN

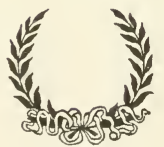

OSWEGO, N. Y.

PRESS OF R. J. OLIPHANT

1900 


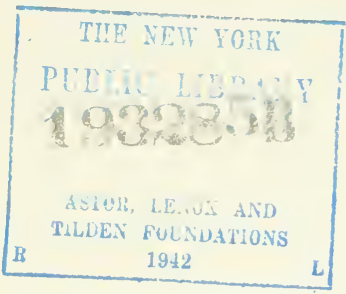




\section{THIS LITTLE STORY,}

WHICH SO IMPERFECTLY GIVES A GLIMPSE OF SOME OF HER LIFE WORK,

IS LOVINGLY DEDICATED TO THE MEMORY OF MY MOTHER. 



\section{PREFACE}

This is the story of my old Lorraine home, and I tell it, thinking it may be of interest to my children or to the children of others of the family. I have not attempted to give an elaborate family history, but have written of the early times in the old homestead and of some of the things that there took place, as I now remember them.

If in this recital the personal pronoun occurs too often, it must be remembered that I am talking, principally, of my own recollections. Neither do I wish to convey the impression that the writer did any more than his proper share of the work or had more interesting experiences than others of the family. Indeed, being the youngest of a family of nine, it is more likely that he, "the baby," had the easiest time of any, and, if any favors were shown, he got his full share.

I intended to occupy but a few pages, but as I got into the subject I found more difficulty as to what I should omit than what to tell, and as material for volumes crowded my mind, I fully realized that the old live in the past, the young in the future.

December 25, I900.

H. H. L. 



\section{CONTENTS}

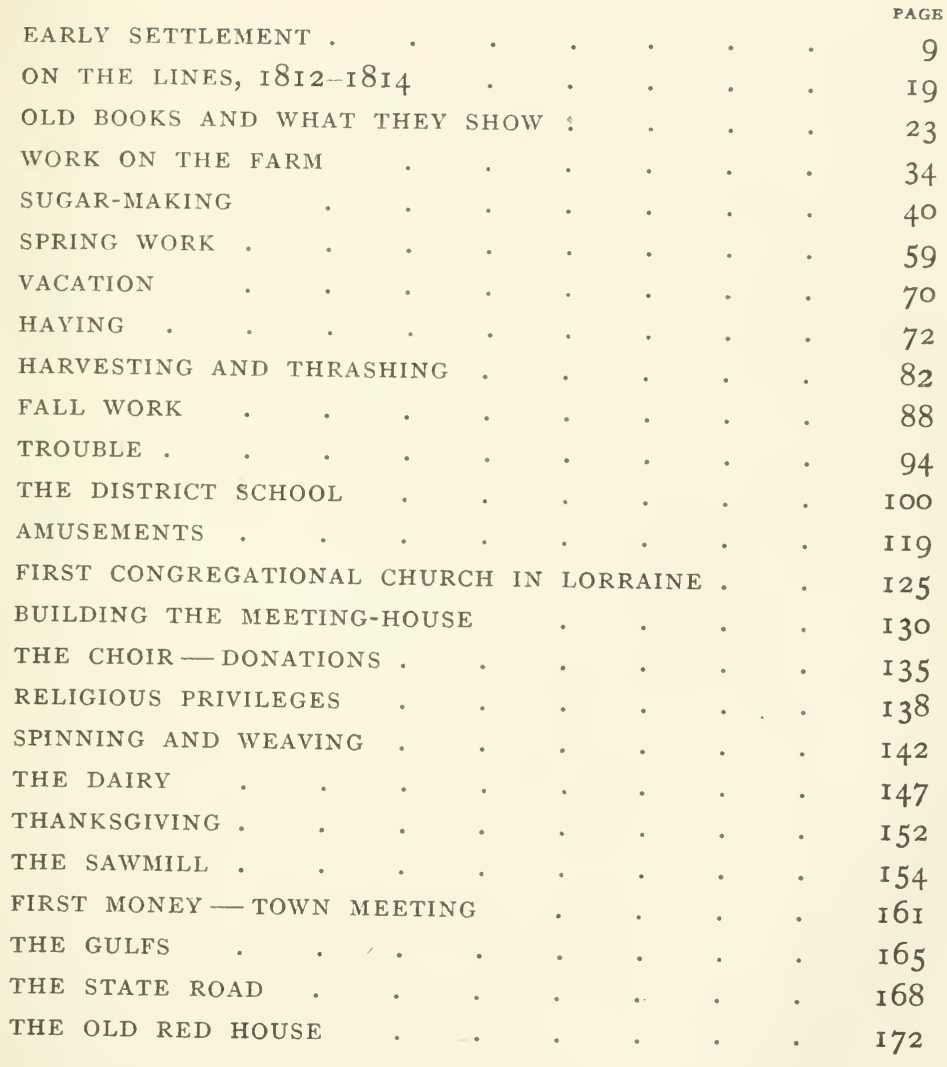




\section{ILLUSTRATIONS}

$\mathrm{T}$ THE HILL MEADOW OLD THISTLE TREE PORK-BARREL ROCK THE OLD MEETING-HOUSE • • BRIDGE BY THE MILL • • • • THE OLD RED HOUSE . . . . KITCHEN WING . . . . .
- FRONTISPIECE FACING PAGE 72

6 6 69

$66 \quad 66$ I2 I

$6 \quad 66$ I 30

$6 \quad 66 \quad$ I 54

$66 \quad 66 \quad$ I72

$\begin{array}{lll}66 & 66 & 177\end{array}$ 


\section{Memories of the Old Homestead}

\section{EARLY SETTLEMENT}

Our grandfather, Silas Lyman, was from Vermont, and moved to Lorraine, then known as the Sandy Creek section of the Black River country, about the year I802. It then was to the people of New England "out West," and was being settled from Vermont, Connecticut and other eastern states, on account of its proximity to their own country, which enabled them to reach it by team.

At the time of immigration he had a family of small children, our father, Silas, Jr., being about eight years of age. The family was very poor, coming into this wild, rough country with but their bare hands and a few of the very simplest tools, with very little household goods or supplies of any kind.

Father was old enough when they moved from Vermont to remember the journey by way of the Mohawk Valley in an ox cart drawn by a pair of stags. This cart contained all their earthly possessions, the whole outfit with which they were to set up a home in the new country. Such of the family as could not walk were packed into the cart with the goods. It was a long, tiresome journey of over two weeks. Soon after passing Fort Stanwix the road became bad and difficult to traverse, and long before reaching their destination they were compelled to abandon the cart and construct a log sled or slide boat, to which were transferred the goods and the little children. This could be dragged over the rough road and around through the 
woods where trees and logs had fallen across the trail, where the cart could not go.

The ax was the principal implement, and it was their best friend and ally. On it, and their ability to wield it, they relied to clear off a small building spot and rear a comfortable dwelling, and with it they manufactured almost everything which they had to use - the log house covered with split slabs or bark, floored, if at all, with hewn plank split from the huge basswood logs; rude house furniture and equipment of all kinds, rough but serviceable; sleds, log boats, drags, troughs for catching and storing maple sap, leaches for making soap, storing troughs for corn or anything else which they had to store. There were no sawmills and no lumber within reach, and these and the many other things absolutely required were all necessarily the product of the ax. In fact, the skilled pioneer with his ax and knife made everything he needed - certainly all that he had.

Grandfather, or some one else, had been there the fall before and constructed a rude hovel and felled the trees in its immediate vicinity, on the north bank of Deer Creek, on what at a later period was the Rev. Enos Bliss farm. This hut was only intended as a temporary shelter, while they looked about for a more permanent location and built themselves a better habitation.

Later on he moved farther down stream, to the south side of the creek, and built a better log house, where he lived until his death, March 6, I8I2. This place was always spoken of as the "old place," and upon the site of the old log house uncle Luther Lyman built a small frame house about 1828 , in which he lived a few years, then gave it up. Brother Gilbert later on lived in the same house.

The home farm was the place first occupied by William 
Brown, our great-grandfather, and upon which the house shown in the accompanying cuts was built and now stands.

At first, no attention seems to have been paid to the location or purchase of the lands. They were for some time squatters in the big woods, with no trouble about lines or claims. They were more anxious to be near other settlers than to secure desirable lands. Grandfather's location proved to be the most undesirable of anything in the immediate vicinity. They brought with them the Vermont idea that flat land was no good; that heavy hemlock, birch and beech timber indicated good soil. For pine lands they had no use. I have heard my father say that they could have had the Adams flats on Sandy Creek much cheaper than the Lorraine hills, but would not take them on account of their being covered with pine and the soil too light and sandy. They wanted a good, durable soil, and they got it good, solid hardpan, filled with shale, flat stones and great hardheads.

The history and occurrences of this early period were told over and over again to us children, and upon me made a lasting impression and are as much a part of my memory as my own actual experience and observation.

The struggle for a bare existence in this heavily timbered, stony, hilly forest was a long, hard one and at times very disheartening. Nothing could be raised until the removal of the great, green forest monsters, and then no plow could be used among their solid stumps and far-reaching roots for years. Such stuff as was raised had to be put in and cultivated wholly by hand.

The shadows were deep and long around their little clearings; the frosts were late in the spring and early in the fall, and once at least they came every month in the year. Winter snows were early and deep and covered the earth until late in the spring. 
Food was scarce, and no one had any more of it than he wanted for himself, unless it was the product of the forest and stream. At first, venison and fish was the principal diet. Later, came such additions to this bill of fare as could be had from corn pounded in a dug-out stump mortar, and a few vegetables raised in the first clearing; and still later, the luxury of cornmeal, procured by backing corn over six miles to Adams, where a mill had been established. Grandmother Brown's brother Stanton was the hunter of the family, and kept them well supplied with venison, which they ate fresh, salted and jerked.

Wild animals were thick, particularly deer and bear, with some wolves and an occasional panther. This interfered with the early raising of pigs and sheep, and father often pointed out to me the spot where he watched the stone bake-oven, while the wolves, drawn by the odor of the cooking, barked and howled on the opposite side of the creek. They were cowardly, and feared only when in packs. But the bears were bolder and more troublesome, and when it came to the raising of young stock it had to be carefully corralled or penned up each night, and even then the bear occasionally got away with a pig or a lamb. But the actual damage which the wild animals did was nothing in comparison with the terror they inspired in the women and children when left alone.

The town settled rapidly, and neighbors, some of them old acquaintances in the East, came in from Vermont and Connecticut, settling close to one another for the mutual benefit of society, roads, schools, and religious meetings. The Pierrepont estate, William C. Pierrepont, agent, owned the township, and sold lands in quantities to suit the purchaser. At first, they bought small lots of from ten to fifty acres only, calculating to add more when required. It was bought upon contract, and 
generally not a dollar paid down, the land owners being glad to sell and relying upon the improvements made and the advantages of settlement for their security.

The rapid settlement of the neighborhood was beyond the expectation of any one, and from I 800 to I 806 there was hardly any part of the Black River country which had so favorable a reputation and extensive advertisement among New Englanders contemplating emigration as the country drained by the headwaters and branches of Sandy Creek.

The uplands were much more popular than the lowlands near the lake, where fever and ague had already shown itself. The rocks and great boulders which you see in the old homestead picture did not scare these old Vermonters, but simply made them feel at home. It was clay hardpan soil, and in many places the shale, or a blue hardpan closely related to and ready to turn into shale rock, was close to the surface. It had little merit except as compared with the Vermont mountains they had left, although with years of hard work it was made into fair grazing lands, producing good grass and other crops, until the top soil or shallow covering of vegetable mould was worn out.

As with most pioneers, they were all farmers and people who knew how to get a living from the soil, and while removing the forest could make it contribute to their support. Among these pioneers were ministers and schoolteachers, but they expected to and did live by manual labor. The lawyer was not with them, as there was little to quarrel over and nothing with which to pay his fees. They had no doctors within a long distance, and serious illness or accident had an increased terror on account thereof.

By reason of hardships and exposure, grandfather contracted 
a fatal malady and died March 6, I812; and father, being the oldest son, under his mother's direction then took upon himself the care of the family.

Our grandmother, Parnee Lyman, was the daughter of William Brown and a sister of Stanton Brown. They were among the first settlers, as before stated, and lived on the old home place, just above the old orchard, three surviving trees of which are shown in the hill meadow picture.

In 1817 , grandmother left town, taking with her the youngest of the children and going to Fredonia, N. Y., where she remarried. This relieved father of the principal care of the family, and he began life for himself.

His first important step, and the most fortunate one of his whole life, was his marriage with Cynthia Waugh, an orphan girl, whose fortune, like his own, consisted solely of good health, courage and ambition to do and be something in the world, combined with superior ability to make the most and best of everything which came in her way. To her is due a large share of the credit for such success as he or any of his children subsequently attained. She was a graduate of the school of hardship and poverty, where she had learned the practical lessons of life - that school which has turned out more strong, independent and successful men and women than all others combined.

She was the second daughter of Dan Waugh and Irene Smedley, of Litchfield, Conn., who both died at Lewiston, $\mathrm{N}$. Y., in the winter of $\mathrm{I} 8 \mathrm{I} 2$, where they had settled and taken up a farm a short time before, leaving eight small children. After the death of their parents this family of orphans, the oldest, Betsey, being then but sixteen years of age, continued to live in their rude pioneer home at Lewiston, on the east side of the Niagara River. They soon found themselves in the midst 
of the terrors of border warfare and in the center of hostile operations under the very shadow of Queenston Heights, and within hearing of the guns of Fort Niagara and of Lundy's Lane. The older ones were even too young to realize the gravity of the situation; but they realized their poverty and helplessness and anxiously hoped to save the beautiful home of their parents and keep the little family of brothers and sisters together. They had promised this to their dying parents. They had nowhere else to go and no means to move if they wished. For a time it looked as if they might succeed; but the employment by the British of hostile savages to rob, burn, mutilate and murder the settlers drove them in dead of winter from the home they had learned to love and hoped to keep, but which they left none too soon to escape the tomahawk and scalping-knife, which the next day was the fate which overtook many of their neighbors, including the kind-hearted physician who had attended their father and mother in their last illness.

As the situation became more critical, those who could went nightly for safety to Fort Niagara, near the lake; but all could not do this and it was impossible without transportation to move the smaller of the children there every night. For months the settlement was guarded by mounted sentinels, who rode about among the neighbors both day and night to ascertain if all was well and to discover and give warning of the approach of the savages. This only served to increase fear and panic, and many of their nights were passed in the adjacent woods, filled with the terrors of expected torture and death at the hands of pitiless brutes.

About this time their uncle Norman, of Camden, N. Y., knowing of the peril that overhung them, hastened to their rescue. Deciding upon immediate flight, he bundled the eight lit- 
tle ones into his sleigh, with beds and bedding to keep them warm and such scanty provisions as were at hand with which to feed them on their long wilderness journey, and drove them rapidly and forever away from the scenes of sorrow, trial and terror which had so darkened their young lives at the very threshold. Taken back to the east, they were scattered among their parents' relatives and friends, each bare-handed and alone to make his way in the world.

Mother found a good home in the family of Deacon Upson, of Camden, N. Y., whose wife was a friend of her mother. They treated her with great kindness and she never ceased to revere their memory, and to tell the many virtues of her foster parents was always her delight.

After their marriage, father and mother immediately began housekeeping in an old log house built by Stanton Brown on the old home farm, where we were all born and where they lived until I 867 , and where for fifty years they labored incessantly, with varied success, surrounded by warm-hearted neighbors as diligent, earnest and poor as themselves.

That there was little to encourage a man in those days in farming, father seems to have discovered very early. It took nearly a generation to clear off the forest and get the land in shape for anything like decent cultivation, and then needed another generation's time to clear off the stone; in fact, that part has never been completely accomplished.

There were no markets for farm products within their reach, and for years and years it was simply a question with the first settlers of getting a bare living and making improvements on their places such as could be done by their own labor. Controlled by these conditions, father looked for something to do that would pay, while clearing up the farm. 
He had early been taught to do every kind of farm and woods work, was handy with all kinds of tools, and had a capacity for doing work which is seldom possessed or acquired by any one. He was not what would be called a "jack at all trades and master of none," but was a natural mechanic, who acquired considerable skill in many different trades without serving any apprenticeship other than that which necessity and circumstances placed upon him, as well as an athletic, strong man, capable of enduring the hardest and coarsest labor. No job was so difficult but that he could see some way through it; no task so hard but that he had energy to undertake it if circumstances demanded. He did not have to go to school to learn the properties and powers of the lever, wedge or screw. No one ever saw him try to lift a big log or rock by taking hold of the short end of the handspike. He seemed to know intuitively how to take advantage of anything that he had to lift or move, and used his brains as well as his strength. Deft and handy, he was also strong, and a continuous use of his strength made and kept him so as long as he lived.

He concluded that the manufacture of potash might be a remunerative business. The town was clearing up rapidly, the timber had to be burned to get rid of it, and by saving the ashes from this burned timber, as well as the ashes made in the house, they had the material for the manufacture of the potash, with the exception of lime, which was easily obtained. Potash in those times was very salable, as the various chemical compounds now used as substitutes therefor had not then been discovered. Acting upon this idea, he established on his farm what was known as the old potashery, near the creek, where later on was built the lower milldam, the ruins of which appear in the cut just above "Pork-Barrel Rock." 
Going into this business, he followed it for several years to a greater extent than he at first intended, and bought ashes, of which there were plenty through the town and adjacent country. Every settler was endeavoring to clear his land, and burned all the wood he could in the house as well as in the fields. The ashes when gathered were put through leaches to get the lye, which was boiled in a long row of big, thick kettles and made into what was known as potash and, by a little different system, pearlash. It required much hard labor, the chopping and drawing of hundreds of cords of wood, the hauling and handling of great quantities of ashes - a heavy, dirty work - and the carting of the potash, when made, over long, bad roads to a distant market.

The potash, when ready for market, was packed in casks holding about five hundred pounds each. Although not a cooper, he learned to make these casks himself, having been disappointed in the services of a cooper and having material on hand from which to make them and a market which demanded immediate delivery of the goods in Utica.

Having worn out what was called the old ashery, he built another below the mill, under the bank and near the old schoolhouse, which in its turn was used several years and then abandoned. The construction of these asheries was mostly by his own labor and from material on the farm. They were run both day and night, and he and his help frequently worked all night keeping up the fires and doing the heavy, hard work required. These asheries, as shown by his books, were operated from I 818 to 1832 . Large quantities of ashes were drawn from all over the surrounding country and leached and thrown out in great piles back of the old buildings. When the asheries went down, rank grass quickly covered these enormous old mounds. 
In the year I899, my brother John and myself were visiting the old homestead. We discovered that the then tenant had broken into the old mound at the upper ashery and had found, after going through the turf, that the old leached ashes were in a condition to be of value as fertilizer, having retained their virtue for eighty years. The man on the farm said that he had made the experiment not thinking there would much come of it, but found that a liberal application of these old ashes on the runout clay soil of the hill meadows had increased the crop of grass from one-half a ton to a ton or more per acre. There were apparently a thousand or more loads to be had from the old mound, which had never given us any curiosity except as a home for woodchucks and skunks that lived in the dry little hill in great numbers.

\section{9}

\section{ON THE LINES, 1812-1814}

By I8I 2 the town of Lorraine had become well settled. The war with England and the laws then existing made every man of military age a soldier, and along the front they were well organized, and among them was enrolled Silas Lyman. Although but seventeen years of age, he was made a non-commissioned officer and served, as called upon, along the frontier, at Sandy Creek, French Creek, Sacketts Harbor, and other points whenever alarms were given. His company was known as the Lorraine company and was under Captain Elisha Allen and attached to the regiment of Colonel Clark Allen. Sacketts Harbor was an important military post, watchfully guarded by our government and eagerly desired by the enemy on account 
of its good harbor and commanding location near the entrance of the St. Lawrence.

They were frequently called to assist at given points at or near the front, each taking his equipments and a loaf of bread or any food that happened to be in the house and making the best time he could to the rendezvous designated by the courier, who was a sort of Paul Revere sent post-haste through the town to notify them of apprehended danger, and they often went on a double-quick for ten or twelve miles.

After the war, father served in this same regiment through various grades. I have his appointment as sergeant in I8I7, signed by Colonel Elisha Allen, and commissions as lieutenant and captain in the years $182 \mathrm{I}$ and $\mathrm{I} 822$, signed by Governor DeWitt Clinton, and as lieutenant-colonel in 1824 , signed by Governor Yates. He never talked boastingly of his military career, always spoke rather depreciatingly thereof, and seemed to feel that it was unfortunate that they had no better line of service than frontier watchmen or minute-men.

His description of the battle of Sacketts Harbor and the maneuvers, tactics and work done by the raw and untrained militia and old "Silver Gray" volunteers seems now rather ludicrous, although at the time I thought it a famous battle. It appears the duty of the company to which he belonged, as well as many others who had been ordered to assemble at Sacketts Harbor to resist the landing of the British, was to move into the village on a road in sight of the foe and quietly get out on another which was not visible to the enemy, thereby giving them the impression that great reinforcements were coming in. This, he said, was the best use they could be put to, as those who had guns had no powder or ball, and many of them, particularly the "Silver Grays," who were volunteers beyond the military age, 


\section{OLD HOMESTEAD}

mostly had nothing but sticks over their shoulders. At the first fire of the British, who were down at Horse Island, the most of the militia, under the redoubtable General Brown, got up and fled towards the town, inflicting no damage whatever upon their opponents, who marched on till they met the little band of regulars and better organized and disciplined militia who were nearer town and made a creditable stand, thereby turning the British back to their ships.

When in his ninetieth year, and a short time before he died, while visiting me at Oswego, I asked him to write a memorandum of his service, more particularly as to the carrying of the cable from Sandy Creek to Sacketts Harbor on men's shoulders, for the famous old battleship New Orleans, then building. $\mathrm{He}$ did so in the following words:

"Statement made by Silas Lyman of service rendered in the War of I 8 I 2 with Great Britain, in Captain Elisha Allen's company, Fifty-fifth Regiment New York Militia, commanded by Colonel Clark Allen: Our regiment was armed and equipped with government arms and ammunition and held as minute-men, and were called out at different times to places on the lake shore. I was at the battle of Sacketts Harbor and at the rescue of property, including guns and equipment for ships at Sacketts Harbor, and at the landing of Sandy Creek in Ellisburgh - in all, sixty or more days. Our company had no other record than the name of turning out promptly at every call. At Sandy Creek, a cable, weighing ninety-six hundred weight, three quarters and twenty-six pounds, was so heavy that it could not be carried on a wagon. It was the last of the property to be carried by land eighteen miles to Sacketts Harbor. Eightyfour men took it up and carried it three miles, about one hun- 
dred and twenty-eight pounds each, then got recruits and went on till night; got more volunteers next day, and at twelve o'clock delivered it to the sailors and had a verbal discharge from the colonel. The said cable was seven inches in diameter and thirty-six rods long."

He then described to me the hurrah of a time they had as they neared and went into the village, when, he said, men were as thick as they could walk under the big cable, and fifers and drummers were riding on it, making things ring and rattle as they moved into town, to the loud cries of "Hurrah, the rope! Hurrah, the rope!"

As long as he lived he had a scar on his shoulder made by this cable carrying, which was caused, as he said he believed, because the man each side of him seemed to be a little shorter than he was. As he became older, he became prouder of his military service, and was particularly pleased with the small service pension granted him, although he lived to draw it but a few months. So far as he knew, he was the last surviving member of his company. His early experience as minute-man along the front and his subsequent connection with the old "Floodwood" militia gave him an active interest in military affairs which he kept as long as he lived.

His oldest son, Gilbert, when a very young man was captain of an artillery company, which frequently met and drilled on the old home farm. A big elm on the bank of the creek near the Wilcox line for many years bore the marks of cannon shot received in target practice. His second son, John N., was a medical cadet, assistant surgeon, in charge of various hospitals and convalescent camps for a long time, and then surgeon and major in the United States Volunteers in the great war; and his third 
son, Henry H., served as private, lieutenant, adjutant and brevet-major, New York Volunteers, in the war for the Union, and was appointed lieutenant-colonel in the National Guard by Governor Fenton. The records of his sons in this line were to the father, whose patriotism knew no bounds, a source of pride and satisfaction.

\section{3}

\section{OLD BOOKS AND WHAT THEY SHOW}

Going back to the old books kept by father at the time he carried on the manufacture of potash and lumber and kept a general supply store, I find much that is instructive as to dates and other matters. They are a complete roster of the first settlers of the town of Lorraine, and include the names of all its early inhabitants, as well as many others of adjacent towns, and very clearly show the business methods and usages of the times. The long list of substantial Puritan pioneers who left New England from 1800 to 18 I 2 to settle and open up this old town of Lorraine is a very interesting one.

The immigration from I 800 to 1806 to our neighborhood was especially remarkable; they were the "boom" years for that section, and the country south and west of the state road filled up very fast. To the old Vermont and Connecticut people who listened to the stories of the prospectors who had returned from this wonderful, newly discovered Black River country, it seemed an Eldorado. Relatives, friends and acquaintances left Vermont in families and groups, and kept near together in locating in the new country. They were all poor, but intelligent and confident, and competent to meet the exigencies of their new venture. 
In our immediate neighborhood, the early settlers were the ancestors of these well-known and numerous families, viz.: The Risleys, Stedmans, Hitchcocks, Foxes, Pitkins, Blisses, Webbs, Bartons, Gilmans, Lamsons, Bakers, Randalls, Gardners, Mileses, Lowrys and others. All had large families, from six to ten. None were too poor to raise plenty of children, who in their turn followed the example of their fathers. The first two generations stayed by their early homes and were content and happy; then came railroads, the telegraph, and the era of discontent and emigration.

A study of these old books revives one's memory as to the personal traits and the peculiar characteristics, habits and history of the founders of these well-known families. They vividly recall the successes and the failures, the good and the bad fortune which have come to their descendants, and show

"How they bought and how they sold,

How they got and used their gold."

Father began the potash business in 1818 and carried it on extensively for several years. It was the first concern of the kind, was centrally located, and drew the ashes from a large area of country from which the forests were being rapidly swept by famous axmen. The business in those days, and for many years afterwards, was almost entirely a barter trade. He bought goods of jobbers in Rome and Utica, giving his notes for the same, "to be paid in potash." These notes were exchanged for ashes purchased from the people of the surrounding country, and delivered either at the factory or upon their premises, as agreed. The ashes were then manufactured into potash, drawn to Rome or Utica, and delivered in liquidation of the notes and in exchange for more goods. The labor employed in 
the manufacture of and the expenses of drawing the potash to market and hauling back merchandise were paid for in goods and with orders upon various parties. Potash sold for eighty dollars per ton in Utica.

Everything was paid for by the exchange of other property. When settlements were made and accounts balanced, it was by giving or taking a due-bill, whether the amount was large or small. These due-bills were mostly on demand and generally were not paid, but brought forward as a debit or credit balance in subsequent accounts with the same parties, or settled in the hands of others. I find due-bills credited for three, five and six cents, which shows not only particularity and exactness in accounting, but that there was no money with which to pay balances. In the many thousands of dollars of values which are accounted for on these old books from I8I 7 to I840, not over one per cent of the total amount is represented by cash.

The books were kept in a simple but plain manner, and when the accounts were extensive each party generally subscribed to a statement at the bottom showing that it had been settled and adjusted. Occasionally, where the account had run a long while between neighbors who were not over-particular, the statement appears, "Settled and jumped accounts this day." Neighbors did not render bills, but brought in their books some rainy day or evening and "looked over" accounts to get at the balance.

The merchandise kept in stock consisted of all such articles as would be of use in a new country, mostly absolute necessities. From year to year the stock seemed to grow in quantity as well as variety. In short, it was a general country store of those days and a "department store" of the present time.

The entries show that the transactions were generally very 
small, particularly in the exchanges made in the ash accounts, in which ashes were the principal item of credit, although many other things entered into the accounts. This was something they could realize on while clearing their lands, and there were none so poor but that they had some to sell, either from the house, field or sugar-bush. They were worth from ten to twelve and a half cents per bushel for house ashes and from five to seven cents for field ashes.

There are more debits in the ash accounts for tobacco and tea than any other articles, tobacco leading. Nearly every customer used tobacco or had some one working for him that did.

In the mill accounts, stone-boat plank and sled-crooks are very frequent. The stone-boat played a very important part in the second clearing of their lands from rock and stone, as did the log-boat in clearing off the timber.

The articles next in demand after tobacco and tea were spelling-books and English readers, and occasionally a Daboll's arithmetic, the spelling-book leading all other books ten to one. This, more than anything else found in the books, tells the story of the character of the settlers. With only a dollar or two coming from their ashes, among the very first things purchased as absolute necessities is found Webster's spelling-book. Noah Webster's spelling-book was a combination of elementary grammar, reading and spelling, and included much information besides spelling. Sixty-two millions of its various editions were sold, and as an educator it outdid any book ever published in America and probably in the whole world.

There appeared to be no illiteracy whatever. No one made his mark; they could all read and write, but their book education was confined to the simplest English branches. Calling to aid my memory in inspecting these old records, I discover 
that those whose ancestors purchased the most spelling-books and English readers have made the best record in the race of life.

Although the times were hard, there is evidence of a taste for some finery, and ornaments and ribbons, beads and fancy buttons were common.

Letter-paper was charged at one cent per sheet; almanacs were six cents apiece, and a lot of them were sold (they were Benjamin Franklin's publications, and, like Webster's spellingbook, were popular and carried much general information); button molds, thirteen cents a dozen; fish-hooks, one cent each; gun-flints, one cent each; pins, one cent for each row; four-foot wood, fifty cents per cord, delivered; chopping same, twentyfive cents per cord; spelling-books, nineteen cents; English readers, sixty-nine cents; Bibles, from seventy-five cents to one dollar and a half; nails, twelve and one-half cents. Prices were not exorbitant, but everything had a value and was carefully saved and cared for. A board, plank or bit of good lumber, old horseshoes, old saws, axes, wagon-tires, etc., were all carefully preserved and made use of.

Iron was high and scarce, as the trade in old iron indicated. Any old worn-out iron tool had quite a value, as it furnished stock to make something else. It was not an uncommon thing to find a charge of one-half a pound of nails to a good, substantial customer, and a credit of an old file or an old scythe at a few cents. These in time went to William Carruth or Morris Haight, famous old blacksmiths and tool-makers. An old ax-poll was worth one dollar, and for a dollar it was "jumped." These "jumped" axes were considered quite as good and frequently better than new, as they were made over and shaped by a practical woodsman as well as a first-class blacksmith. The expression of one 
highly elated and happy, that he feels "like a new jumped ax," is yet common in wood-choppers' parlance.

The ink used on the books, both black and red, was homemade, some of it being as black as jet and standing to-day as well as when written, while some is badly faded.

The entries were generally quite specific, thus enabling one to get more information than from books kept by what might be considered better methods. For instance, "Calvin Totman, by cash paid in road before your house, fifty cents." The payment of so much cash was remarkable and needed special mention to avoid misunderstanding.

Alfred Shaw's account states as follows: "August 8, I 822, Alfred Shaw began work at one hundred dollars per year." The kind of hired man that Alfred made is revealed by charges for lost time: "One day, going fishing;" "one day, hunting;" "one day, attending a frolic;" but the charge of July I9, I823, is the one which gives Albert completely away, viz.: "One-half day napping, after courting," which, at one hundred dollars per year, cost Alfred just seventeen cents. Seems cheap enough, but all depended on the sweetheart.

The "pie-eater" existed then as well as now, as indicated by the charge, March 7, 1826, "Benagah Lowry, one pie at town meeting, twelve cents."

The "gingerbread boy" was also abroad the same day in the person of Isaac Lanfear, who is charged with "gingerbread and drink, six cents."

The same day, March 7, Simon Wheeler is charged with "one-half pint of drink, to be paid in ashes." The quantity of ashes required to "suage" Simon's thirst is not stated.

These and a few other similar charges indicate that March 7 , 1826, was a lively town meeting at the corners. 
I find no other record of town meeting held at the old home, and reference to the town records shows that town meetings and elections for many years alternated between John Alger's and Lem Hunt's places. The record of this town meeting of March, I 826, shows that Ozias Barton was chosen moderator. "Elected John Boyden, Esq., supervisor." Among the items of business transacted at this meeting are, "Resolved, that the owner of every ram found running at large from the Ioth of September to the Ioth of March shall pay a fine of five dollars, one-half to the complainant and one-half to the support of the poor." Again, "Resolved, that if any horned cattle are allowed running at large within twenty rods of any tavern, the owner shall pay a fine of one dollar. Adjourned to Lemuel Hunt's house."

These resolutions indicate that the electors of the town had a proper appreciation of the rights of rams, and, with a commendable solicitude for the welfare of horned cattle, did not propose to have them demoralized by loafing around taverns.

Augustus Baker is credited with "two fat wethers, and boy to take them home, four dollars fifty cents."

Luther Stedman is credited with "one cock hen, thirtyseven and one-half cents." This was probably a "crowing hen."

November I3, I8I7, "Job Lamson, to tarring your wagon before going to Rodman, twelve and one-half cents.'

Such specific memoranda left nothing to be explained or disputed when the day of settlement came, which was generally once a year on "running accounts."

There was quite a trade in Bibles and Testaments, but their effects and results were not so readily traced as those of the spelling-book and the reader.

In the account of one old father in Israel may be found a 
charge both for whiskey and a Bible. In his particular case, I know that the two things did not "work together for good."

Every man of military age was an enrolled soldier, liable and compelled to do military duty. The terms of actual service, consisting of special and general trainings, were short, but the requirement of actual service under the "Floodwood" militia law was imperative, and I find numerous charges, "To paid your fine, twenty-five cents," entered against those who failed to turn out when "warned," showing that "militarism" and "imperialism" of the most drastic kind then existed. But they seemed to enjoy it. No one had yet explained its dangers, they despised tories, and all took pride in standing by the government and upholding its flag.

At these gatherings it was the custom of almost every one to have a general good time. For instance, "Team to general training and your share of rum, thirty-seven and one-half cents." This charge being made against three or four well-known young men of the neighborhood shows that, while they were not on any expensive blow-out, each was expected to keep up his end.

These general trainings also seemed to make a demand for and turn loose a little actual cash, and I find several instances where from two to four shillings were borrowed of father by people at general training. I also find one of the reliable deacons of our church in 1824 with this charge against him, "To pay your whiskey bill at training, thirty-seven and one-half cents." Father was then lieutenant-colonel of the Fifty-fifth, and it looks as if he had to put up for the boys either to secure good order and military discipline or to maintain his own popularity with the line.

As my memory of my father was only that of the strictest temperance man, I was not exactly prepared to find charges for 
whiskey, although I do remember hearing the matter talked about and hearing him tell when he first decided to teetotally abandon the use of liquor, notwithstanding that at that time it was made, sold and used by everybody who pleased, without unfavorable comment or criticism.

There were several distilleries in town. The whiskey was good and cheap, and its use at raisings, logging-bees and all kinds of gatherings for business or pleasure was the universal custom.

The first sale of whiskey charged was November 2, I8I 5 , to John M. Williams, viz.: “Three yards of flannel, five shillings per yard, one dollar eighty-eight cents; three gallons of whiskey, seven shillings per gallon, two dollars sixty-two cents." There is nothing in John Williams' account to indicate out of which he got the most warmth, the three yards of flannel or the three gallons of whiskey.

There are a few other charges on the book indicating that rum and whiskey were sold at his store in jug quantities, but not, as a rule, by the drink, although I find items in 1826 of this character: "Stuff at election, twelve and one-half cents." Probably this was rum, as that was the "stuff" most in demand at elections in those days, yet it indicates that even at that early day he had begun to be sensitive about the trade and did not care to make an entry on his books showing that it was liquor, or that the customer did not want it so charged.

Four or five years cover all the entries for liquors, and whatever he may have thought of the business then, he condemned it as a curse and an abomination throughout the balance of his long life, and was active in all reform measures taken for the suppression of the traffic.

I find a record of notes given for so many days' labor, and 
receipts to correspond, made out in days' labor, money not being mentioned in either. Entries are often found specifying the kind of goods in which payment is to be made. For instance, "Truman Webb, one calf, to be paid in salt." How much salt it took to liquidate a calf in those days we must guess.

Legal work in the surrogate's court came cheap, as shown by the charge, "Alfred Webb, to appraising your father's property, with Elijah Fox, fifty cents."

That they supplied themselves with salmon from Salmon River in very early times, appears by several charges for a "team to Richland to fetch back fish."

When exchanges or trades were made, the difference was called "boot," and was stated in the account, as in the following: "Luther Stedman, boot in cattle, three dollars and fifty cents."

Although many of these old accounts seem to have been made with men of extreme poverty, many charges of six or eight items aggregating less than a dollar, with three or four exceptions all appear balanced and paid. Orders given on the store and other people in trade, or upon one another, and duebills given in settlement of accounts, seemed to pass around as currency, instead of being liquidated when due, and some of them are shown to have passed through several hands without liquidation.

And so they went on from year to year, trading, trafficking and dealing in all kinds of property, presumably making money but never seeing it.

\section{BARTER NOTE.}

("Benjm. Wise Note, 32 Sheep, payable June 5, 1828.")

"Value received. Four years from this date I promise to pay 
Vashty Lyman or bearer, thirty-two good, merchantable store sheep, to be delivered at the now dwelling-house of Silas Lyman, in Lorraine - eighteen of the above to be ewes and six lambs - no rams.

Lorraine, June 5, i 824.

Benja. Wise."

A man with a mechanical turn, with a good stream running through his farm on which were good mill-sites, and constantly in need of lumber, could not live long surrounded by a forest without having a sawmill, and in 1823 the old or upper dam and mill were built. The flume was raised October 4, I823. The dam was a large one and the mill was not completed and running till 1824 . As with the potashery accounts, the books are full of barter trade but no cash entries. Logs were sawed on shares for customers, and the one-half going to the mill was marketed the best way possible. The farm and potashery and store did not give him work enough, so he had to have the mill, with the business of cutting and hauling logs, sawing and drawing lumber, which in turn was exchanged for lime, salt, brick and other kinds of property desired. This old mill went down about 1838 and a new mill was built near the four corners west of the house, about the year 1842 .

He liked work in which there was more interest than the routine labor of a small farm, and in 1827 he built for John $\mathrm{H}$. Whipple the old stone block in Adams. He lost largely in doing the job and did not fully recover financially until he fell back upon the dairy, using the profits derived from that source for several years to make good the amount lost in one summer as an amateur contractor and builder.

He built the school-house in District No. 4 in 1828 , and the Congregational meeting-house in 1830 ; this last was an unfor- 
tunate enterprise not undertaken for gain, but resulting in serious loss. He had tireless energy, and had he lived in a time and country which afforded opportunity, would probably have achieved greater financial success. The energy he expended in wearing out those potasheries and sawmills from I8I8 to I845, would have made him a million of money in any manufacturing town; or the work he did on that stony, clay farm from I 802 to r 867 , would have made an independent fortune for a dozen men, if laid out on good, arable land, within reach of good markets.

After the potashery with its store was gone, and the old mill worn out and abandoned, there seemed to come a time when the business of farming proper began to occupy father's attention; in fact, he had carried on the work of farming so far as clearing up the land was concerned quite thoroughly, but did not give it any considerable attention as a means of income until the other industries alluded to were practically abandoned.

\section{3}

\section{WORK ON THE FARM}

The winters in Lorraine were apt to be stormy and hard. Except the lumbering, no great deal of outdoor work was done from the time winter set in in earnest until the sugar season came and the thawing of the creek allowed the starting of the sawmill. This does not mean that there was a season of hibernation, although there was somewhat of relaxation from the activities of the spring, summer and fall. The children and young folks attended school for about three months each winter.

The outdoor work which was pushed between storms was 
that of cutting and hauling wood for the use of the house, and occasionally a little to sell, which had to be drawn six miles to market. This father never cared to do very much of, although many of the neighbors made it quite an industry.

The mill was run until it "froze up." Then came cutting and drawing of logs to be sawed the next season. The mill, however, was run principally as a custom mill. There was cedar to be cut and drawn from the cedar swamp, five or six miles away, to make fencing and provide material for cooper stock. Private and public roads had to be broken and kept passable; this was no light job, and some winters it seemed to be almost interminable. The cattle had to be cared for and fed and watered three times a day, and in stormy weather their roads and paths must be shoveled to the water-trough or, when it failed, to the drinking-holes in the little brook in the back pasture or to the creek.

Breaking and opening public roads was and is still done by the combined efforts of neighbors who turned out with teams, men and shovels, and dug and tramped their way through big drifts the whole length of their road beat. When opened so as to enable a team to wallow through, sometimes they were still further improved by being plowed or kettled out. Huge drifts were often formed so that it was necessary to shovel a canal for a long way, making side cuts for turnouts. This was hard work for both men and teams, but in public-spirited neighborhoods, of which our old District No. 4 was one, it was always faithfully performed.

Father always had work indoors when the weather was too rough or cold to be out. In early days, before the advent of the thrashing machine, the winter's barn work was extensive, as all the grain had to be thrashed with a flail. 
He had taken up the cooper's trade from necessity, in connection with his early potash business, and, finding that he could do good work in this line, he supplied himself with tools, many of which he made. The jointers, croze, squeezer, benches and all the woodwork of the outfit he made himself, and a handy blacksmith at the "huddle," by the name of Carruth, forged the shaves, compass, adz and other iron tools from old files and saws discarded from the sawmill. The whole kit cost but very little, yet was complete and answered well their various purposes.

He built a small building, which he called the "cooper-shop," in which to do work. Staves, heading, hoops, and all necessary stock for making tubs, pork-barrels, casks, cheese-casks, buttertubs, sap-buckets, pails, and all other kinds of cooperage, were provided and kept on hand to be worked up winters, stormy days, or sometimes evenings if necessity required.

This night-work in the cooper-shop was a much-dreaded matter to me, for as a matter of course, being the boy, I had to hold the light - a long tallow candle in an old, black iron candlestick - while father was at work. I was tired and sleepy and could not keep myself awake, and the minutes seemed like hours and the hours like ages as I nodded and dreamed while he worked. He whistled in a kind of whisper which was a habit he had, and his work and the old tunes kept him wide awake.

"Hi, there, boy!" says father; "wake up and hold that candle so I can see the compass-mark."

"I can't tell whether you can see it or not," I answered.

"Then hold the light so you can see it yourself and that will do for me," was his reply; but my head was again falling off my shoulders and the grease dropping in the shavings the next minute.

Now that I am in the cooper-shop, I might as well tell more 36 
about it. Primarily it was what its name indicated, but had other uses also. It had a big arch with a large kettle set therein, which was used to cook feed for the hogs or heat water for butchering, soap-making and other work. With this arch was connected a large chimney, the inner side of which was open for about five feet at the base, thus making a huge fire-place, in which barrels, tubs and pails were heated in making tight-work cooperage. In the spring-time a large cauldron kettle was swung in this fire-place for sugaring-off the syrup brought from the sugar-bush. The attic of the shop was filled with seasoned choice pieces of lumber, suitable for making and repairing all kinds of farm implements. There was a dark cellar under a part of the building, filled with potatoes, apples and other vegetables, when there were more of them than could be stored in the house cellar.

The cooper-shop was also a storage-room for carpenter's tools, of which there was a moderate supply of the most common and useful. Frequently, in very cold weather, father would move his light cooper work - that of making cedar sapbuckets - into the south part of the big house kitchen, where he could be more comfortable and sociable. When small, this I thought was a jolly arrangement, and I enjoyed helping "set up" and "heat off" the buckets and playing with the staves for cob-houses and the shavings for bonfires in the big kitchen fireplace.

The women of the house never approved of this invasion of their domain. It was a nuisance and an interference with their daily work, but it suited father, and as cedar sap-buckets were a specialty with him and a branch of coopering from which he derived quite an income for his winter work, he had his way about it without any great deal of friction. 
The reference to making buckets calls to my mind a little matter personal to myself, which always occurs to me when speaking of cedar sap-buckets.

One stormy day, father and myself were riving staves and heading from bolts of cedar in the big woodshed. The floor was covered with chunks of cedar bark and other debris of the work. I was waiting on him by passing the bolts and tools and riving the less difficult blocks into plain staves, he doing the heading and such work as required more skill. Having used up a block of heading, he said to me, "Henry, pass me another block." I heard him distinctly, but I had fallen into a disagreeable and foolish habit of making the reply, when spoken to, of " $\mathrm{H}-\mathrm{e}-\mathrm{y}$," drawing the word at that. What I did it for I do not know. Many, both young and old, do the same constantly, not that they do not hear, but to make the speaker repeat. Sometimes it may be to gain time to think, but not usually. It is used in different forms _-"Hey?" "What?" "What did you say?" or "Beg pardon?" - the last, perhaps, the most common of all.

Father looked at me sharply and said, with very low and quiet voice, "Did you hear me?"

I felt something was wrong and promptly answered, "Yes, sir," and got and passed him the block.

He picked up his frow, looked at the block, set the frow and brought down the mallet which took off the slab, then addressed himself to me, saying, "I have noticed that for some time past you have answered me and others with that meaningless and insulting word or sound of 'Hey' when spoken to. Are you getting deaf, or why do you do it?"

I said I did not know why.

"Then," said he, "never answer me or any one else that way again. Do you understand?" 
I said that I did. Then we went on with our work.

In about twenty minutes he again spoke to me, saying, "Henry, hand me the crooked frow."

I heard him plainly, as he sat on a block not five feet from me. I knew what he wanted and intended to get it at once, but, from force of habit or some unaccountable reason, I answered up promptly, "H-e-y?" He raised up a little from the block on which he sat and, reaching forward, gave me a cuff on the side of the head with his hand which sent me about six feet towards the east end of the woodshed, into the chips, shavings and rubbish there accumulated. He did not say a word, neither did I. The case was closed and didn't seem to need any argument. I picked myself up and got back to my place, handing him the tool he asked for. At the time I felt that it was a very severe and sudden punishment for the crime, but from that day to this I have never used the word "Hey."

Father was a stern and rather severe man in the control and government of his children, particularly the elder ones; but this and one other instance are the only times he ever struck me, and upon both occasions it was because he was provoked beyond endurance. But in neither instance did he say a word by way of lecture. The good effect of the castigation was not lost or obscured by apologetic preaching. In fact, no explanation was needed. I got the idea all right. It was good for me, and made an impression which will last as long as I live, and to this day I never hear that saucy and impudent interrogation, "Hey?" but that I think of the "crooked frow" and the woodshed. 


\title{
SUGAR-MAKING
}

\author{
"Among the beautiful pictures \\ That hang on Memory's wall, \\ Is one of the dim old forest, \\ That seemeth the best of all."
}

With the coming of spring, and usually in the fore part or middle of March, the sugar season opened. School was "out" for the winter and all of us were ready for the spring's work. Our sugar-bush was a mile from the house and detached from the farm. It was a wood lot of about one hundred acres, covered with all kinds of hardwood and some hemlock timber, and had on it about six hundred maple trees, from old giants of from four feet in diameter down to ten inches. In places the maples were thick; in others, scattered. It has been used as a sugarbush from the year I 802 , and is still in use, a few of the trees now standing which have been "boxed" and "tapped" for a hundred years. These forest veterans have never been belittled by being called a maple orchard or a sugar orchard, but have always kept their ancient and honorable title of "sugar-bush."

The first work to be done upon the approach of the opening was the overhauling of the buckets, getting them out of the shanty or sugar-house and scattering them around to the trees so as to be ready for tapping when the first run of sap should come. This was considered essentially boy's work, and was done by means of a large, light hand-sled with thin, flat, bent runners four inches wide, cedar raves and light beam knees, which could be easily hauled over the crust on top of the snow with a load of fifty buckets which held from twelve to sixteen quarts each. There was sure to be a fair crust at this time of year, as the winter snows were still solid and three or four feet deep. 
Scattering the buckets was play as well as work, as it meant sliding down the hills, of which there were some in the woods, upon the return to the shanty, empty, for another load.

The old arch in the shanty, which was a home-made affair, was repaired annually. It was built of mortar made of blue clay from the bank of Deer Creek where we crossed it in going to the woods, rather than lime or cement, which would cost money. The storage-tubs were scalded and cleaned, the snow shoveled off the shanty to prevent its breaking down, and off the platform on which the storage-tubs were to set, and cleared away from the front of the shanty and off the woodpiles, and everything put in shape, so far as could be, for the expected first run.

The wood for boiling had been cut, drawn and piled under a cover of boards the year before. Sometimes quite a time would elapse between the getting ready and the coming of the sap. In that case the time was spent chopping wood at the sugar-bush, or perhaps in drawing manure to the fields from the great heaps which had accumulated at the cow-stables through the winter. The sawmill, which had been frozen up, had to be "cut out" and thawed out about the same time, in anticipation of the spring sawing.

We watched the weather and signs of its changes closely, and were glad when it softened so we could begin tapping the trees. When the weather came right so that the sap began to climb from its frozen winter home in the roots towards the treetops, an early start was made for the woods, taking along such implements and outfit for the work as had been stored at the house over summer. A big, red bucket pail of dinner was provided, as we could not be home until dark. Talk about the "full dinner-pail:" good gracious! you ought to have seen that one filled by Mother Lyman. McKinley's was nowhere beside 
it. It held just sixteen quarts - no sixteen-to-one affair, eitherand was always full to the ears.

The work of tapping was extremely hard, as each tapper had to carry a large bucket of "spouts" or spiles, which were made of sumac with the pith punched out, or cedar eight to fourteen inches long bored with a gimlet - the making of which was another boy's job; a three-quarter-inch bit, and brace which was a clumsy wooden concern; a shovel to clear away the snow, and an ax to break old dead limbs and chunks with which to set the buckets firm and level. Sometimes the tapper did both the boring and drove the spiles, which was the more important part of the work and required some skill, as well as good judgment where to bore, avoiding old cuts and wounds, so as to insure the best flow of sap; while another, usually the boy, tagged on with the load and "set" the buckets. Later on we wired our buckets with a loop or ear to hang them, and drove a spike with a beveled point, made from the backs of old scythes, under the spouts and hung them thereon. Still later we used a short, cast-iron spile and hung the buckets upon it.

The work of tapping was doubly difficult and hard if the snow slumped - and it usually did in good sap weather. It then became an all day of wallowing in the wet snow over our boots, and sometimes, in going over logs, we got in clear to our waists. With tow-strings we tied down our pants, but they, as well as boots, were soon completely soaked.

When the tapping was done, the next work was breaking out the roads around through the woods for gathering the sap. This was hard and serious work for the horses, who frequently caulked and cut themselves or their mates. When the snow was very deep and made it too hard and dangerous for the double team, we used one horse, hitched to a large pung sled 
with wide runners that would not sink in the snow, and thills of young round birch that a horse could lie down on and not hurt or get hurt thereby. Old Dick, though stone blind, would feel his way along safely and carefully in three or four feet of snow, with a fifty-pail gathering-tub of sap and a boy on the sled behind him. As the snow went down two horses could be used. The woods were rough and full of cradle-knolls, fallen trees, big logs and rocks.

To systematize the work the "bush" was divided into what we called routes - pronounced "routs," not "roots." These routes or sap-roads were laid out as best they might be to lead around old fallen trees and obstacles not easily removed, anywhere a sled could be drawn, keeping within the shortest distance possible of the maple trees, so that in but few cases did the sap have to be carried by hand in buckets more than fifteen or twenty rods. These routes were named and systematically gone over, and were so arranged that ordinarily the run of all the trees on any given one could be put into a fiftypail gathering-tub, to be drawn to the sugar-house. This gathering-tub was larger at the bottom than at the top and made of inch pine, and had a twenty-inch hole in the top, closed by a tight-fitting cover. The sap was thus gathered, drawn to the sugar-house and dipped or pumped with a tin boat-pump from the gathering-tub to the great store-tubs which stood on the platform outside the house.

The boiling or reducing to syrup was done in Russia-iron pans on a long arch - two and, later on, three pans in a row. The back pan was about seven by three and a half feet, and nine or ten inches deep; the middle and forward ones were about three and one-half feet square. A little trough led from the "feeder" store-tub, and as the sap boiled down it was dipped 
into the middle and forward pans. The forward pan was used to "syrup-down," and when sweet enough or thick enough, the syrup was dipped out to be drawn home and sugared-off.

There were very many items of knowledge which it was necessary to possess in this work in order to be successful. For instance, to know when the syrup was right for taking from the pan, the test was whether or not it would "wink." By that was meant, when the last drops of syrup would hang slightly to the edge of the dipper or some other dish when inverted, and then let go suddenly. When it reached this point the fires were drawn or banked and the syrup dipped out, otherwise it might be burned and spoiled.

It was important also to know how to prevent the sap rising, foaming and running or boiling over the edges of the pan, which it would do in the latter part of the season, particularly after the buds began to swell. To avoid this danger we always had on hand butter or pieces of fat pork or pork rinds with which to rub the edges of the pan and to throw into the boiling sap. Then it might boil and foam up two or three inches higher than the edge of the pan for some time without going over. A dash of cold sap would also answer, but was only a temporary remedy.

The seasons varied. Some were short, with the regular, good runs, with freezing nights and thawing days for only three or four weeks. These we liked best, although they drove us hardest. Others were long, with stormy and cold, dry weather; spring, and the coming out of the buds which closed the sugar season, lagging along until nearly or quite the first of May. Intervals in which the sap did not run were improved in cutting and hauling up wood for the next season. Green wood was an abomination, but we sometimes got caught short and were compelled to use it. Every fall we drew a large pile of hemlock 
slab-wood from the mill and used it in connection with the hardwood, not to save wood, but because it made a quicker, better fire.

The big "fore-sticks," which were logs eighteen inches to two feet in diameter and three and one-half feet long, were used green and were rolled up to the front of the arch, and made a support for the ends of the long wood while burning under the pan. A draft space was kept clear under these logs, and they added to the intensity and durability of the fire. The shoveling out of the hot and rapidly accumulating coals which closed the flue under the pans, and the getting into position of these great fore-sticks, was a problem for the small boy or the large girl when left alone to boil; but they managed to do it somehow, and thereby acquired engineering skill and confidence and ability to overcome worse difficulties.

The family usually did the work, but when the sawmill was rumning sometimes a man was hired to help a few days, and even at times the mill was shut down for a day or two to take care of an extra rush of sap.

When father, my brother and myself were all working in the bush, the routine was this: At daylight mother came to the foot of the stairs and called to us, "Come! boys, time to get up. It looks like a good sap day. Come! Come! Here are your dry pants," at the same time giving them a toss onto the landing or turn of the stairs; and a few minutes later, "Henry, your breakfast is ready. Come right along." And, yawning, stretching and sore, I got into the partially dried pants which were left under the old elevated-oven stove in the kitchen over night, and came down. Putting my feet into the half-dried, water-soaked cowhide boots, I kicked and kicked against the mopboard until I jarred the old black Bible off the window-sill 
where it was always kept, in a fruitless effort to pull them on. Father had already greased his own and all our boots with a mixture of tallow and lamp-black from the little quart kettle in which he always kept the grease ready, the same now bronzed and used as a match-safe on the mantle in my room. If the boots would not go on I greased them inside and made a second and usually more successful trial, picked up and returned to its place the old calf-bound Bible, the reading of which I was not to hear that morning, and sat down alone to the early breakfast prepared exclusively for me. It was always a good one: ham and eggs, creamed potatoes, fried pork and cream gravy, wheat bread, corn bread, long, white nutcakes with cider apple-sauce, coffee made from fresh browned barley, with thick cream - two or three big cups - and topped off with a big, fat piece of custard pie. I often suspected that the family breakfast which came later, although it was enjoyed much more leisurely and with Christian observances of saying grace, prayer and Biblereading, was often inferior to my own.

Thus fortified, I started for the woods over the hubs or through the mud, whichever it was, and generally had a roaring fire under the pans before the sun was over the Pitkin hill. This early start insured the "boiling-in" of fifty or sixty pails of sap before my father and brother or the hired man reached the woods with the team, ready for the work of the day. With a good run it was rushing business, and exciting as well. The boiling must be pushed so as to keep storage room ahead, else the sap got the start and the buckets ran over. The rapid click, click, click of the dropping sap, particularly after sundown and early in the morning, was sharp notice to us to hustle. It meant gathering all day and boiling all night, rain or shine.

Maple trees do not all give down sap alike. They are as 
different as cows. There are good, bad and indifferent ones, and in scattering buckets knowledge of each one's habits was required, so as to put only large buckets to good trees and the small ones to the poor yielders. I remember one tree in the "Over-Jordan" route to which we always placed a half-barrel dash-churn and tapped it with two spiles instead of one. This churn was as often full as common buckets at other trees. She was a Holstein. Sometimes, when badly crowded for storage, we used to go around and take from the buckets of the good trees and fill into those of the poor ones, which we called "evening-up," so that when that particular run held up we would have every store-tub and nearly every bucket in the bush chock full, or at least well filled, with some running over.

Sometimes we left the fire to run itself while we went to gather a route, but it was unwise and unsafe to do so, as it would go down and the pans not do their best, or the boiling sap was quite likely to rise and run over, particularly toward the end of the season, when the buds were swelling or some of the utensils had soured. When a great rush was on, some one had to stay by and tend the fires, and this was occasionally done by some of the girls.

Although boiling all night was by the boys considered good sport, I cannot now see where the fun came in. Then it was counted funny enough so that the neighbors' boys wanted to be in it, one reason for which I will give further on. We would get in a half-cord of wood and close the door, play games and tell stories. We had buffalo-robes and blankets and a rude bunk on which two could sleep. We sugared-off in an old longlegged spider and ate wax until we were thirsty, and then drank sap to quench our thirst, which made us still "drier." We ate our midnight luncheon probably before nine o'clock, as we had 
no watches and went by our stomachs. Then, when all this revelry had been gone through with, one of us would go to sleep while the other "biled." The nights seemed an age, and to see the great streak of light in the east was the pleasantest part of it. The morning found us stiff, sore and lame, with our eyes badly smoked and running out of our heads, but we were proud of the work accomplished.

The syrup was drawn down home each night and sugared-off there by the women folks. This was the most particular part of the work, and required great care, patience and good judgment. The syrup, after settling, was slowly strained through several thicknesses of flannel cloth, put into the big kettle and slowly heated. Then milk was put in to clarify it, and a scum composed of all impurities and foreign substances fine enough to get through the strainer gradually rose to the top, which was carefully skimmed and reskimmed until it was all removed. The fire was then started up and the syrup was gradually boiled down thicker and thicker, until it reached the granulating or crystallizing stage. It had to be carefully watched or it would rise and boil over, or burn on the bottom of the kettle. A basin was put in the bottom of the kettle, around which it could bubble and boil without burning. The least trace of burn spoiled the whole batch. As it approached the condition of sugar it would sputter and blubber, forming great, deep holes which would blow out steam like a miniature crater. It could not be left a minute, and the kettle, which was suspended from the end of a strong pole, was raised and lowered and the fire modified as required.

There were two ways of telling when it was done to a granulating point: first, when it "flaked"- that is, would cleave off the edge of the dipper or skimmer in long, thick flakes - or, 
second, when it "cracked"- that is, when a little of it dipped onto snow would lie on the top of the snow and immediately harden into clear, hard wax which would break when bent. Both methods were usually adopted to make sure. Then the fire was drawn and it was allowed to cool in the kettle, being rapidly stirred about meantime until it became a thick, sticky mass through which the stirring-paddle could hardly be pushed. It was then dipped out into milkpans or other vessels to cake, which it did, becoming harder and harder the longer it stood. If caked sugar was not desired, it was "stirred off" - that is, constantly stirred with a long, strong, wooden paddle until dry, but not allowed to cake or harden. If thick syrup or molasses was wanted, it was not boiled to the flaking point, but taken off the fire when about half-way between a "wink" and a "flake." The skimmings were saved and made excellent vinegar.

Of the sugar parties you read so much of we made no great account. It was a constant sugar party from March to May, and mother's only anxiety was that the children and their friends and visitors should not eat so much of the wax as to get sick. How much could be done in that line was occasionally tried by some greedy urchin who got the worst of it. I remember a joke or trick we practiced on the dog, who also liked the soft, sweet stuff. A bunch of the stiff wax was rolled up, put in his mouth and his jaws shut tightly together. Of course, for a long time he could not open them, and went through very funny antics, running, rolling and pawing, but, like "Tar-baby," saying nothing until it softened up and released him.

At the close of the season, having drawn up the wood for the next year during odd times, the buckets were gathered, "scalded" and packed away in the sugar-house, which they 
filled from the earthen floor to the roof. The tubs were also properly cleaned, nested and put under cover, and the sugarhouse fastened up until next year.

In visiting the old sugar-bush with my brother John in July, I 899, we found the same store and gathering tubs in use which father made and which we used fifty years ago, some of them having been in constant use for seventy years. Many of the old trees were yet alive. They looked like old friends and acquaintances, and we greeted them with pleasure, recounting the virtues or failings of each. The younger ones - those of forty or fifty years' growth, which are now taking their places looked like strangers and interlopers, and we spent no time talking to or of them. The old routes, which I could follow with my eyes shut, were somewhat changed, and some apparently abandoned.

The impressions made on me by my early sugar-bush work and experience were more permanent than anything else in the line of farm work that happened in my early days. It was the work that I liked above all other which I had to do. The uncertainty of the thing helped to give it zest and interest, for it was a kind of gambling guess as to what each day would bring forth. It made a permanent impression which I have never shaken. In my dreams I have boiled sap many a night, and sometimes when wakeful, for want of some better occupation, or in an attempt to court sleep, began with what we called the middle route and gone around the sugar-bush to every tree, thinking of the peculiarities of each, and followed the crooked, rough roads over logs, through pitch-holes, swales and swamps, through the hill route, the Pitkin route, the upper route, the side-hill route, the hemlock-hill route, the swamp route, "Over Jordan" and all the rest. I have counted the trees to see if 
they were all there, boiled nights, sugared-off, and gone through all the various operations which the alchemy of the mind so readily and vividly reproduces.

The beauties of the sugar woods when the great pall known as "sugar snow" hung on every limb and twig, to me have never been surpassed by any pictures which I have seen or any forest scenery which I have had the fortune to look at. Sap gathering, with the sugar snow letting go the limbs and falling on and about you until every thread of your clothing was soaked, was not so romantic.

The sugar-bush work was hard, smoky and wet, but I liked it, and my liking it and knowing how to do it well gave me plenty of it. There was an uncertainty and excitement about it that was interesting and stimulating, and, to the boy that I was, the responsibility so early placed upon me of occasionally bossing and running the sugar-bush alone, swelled my pride - and probably my head.

The work came at a time of year when there was not much to be done on the farm, except taking care of the cows and the cattle. It paid well, as all sugar was then dear, and good maple sugar was salable at twelve and a half cents per pound. We sometimes made twenty-five hundred or three thousand pounds of cake sugar, besides plenty of syrup and molasses, which supplied the family for the year and left a couple of hundred dollars' worth to sell or exchange for other merchandise.

I have been writing of the method in vogue in my father's sugar-bush from 1845 to 1867 , which came within the scope of my own personal recollection and experience. Back of that, maple-sugar making was done very differently. The trees were "boxed" with an ax, instead of bored with a bit. In fact, they 
had no bits in early days, and their augers were clumsy things and what is known as pod augers, having no center directing screw. Boxing consisted in cutting a great gash or hole into the side of the tree with an ax, the lower part of the box or cut being made at an obtuse angle with the heart of the tree, and the cut made slanting towards one side, so that the sap ran to the lower corner for an outlet. A semi-circular chisel called a gouge was then driven underneath the outlet corner of the box and a flat spile, whittled to fit the incision or cut of the gouge, inserted. Boxing was early death to the trees, but no one cared for that as trees were plenty. In fact, their removal was considered a benefit rather than damage.

Troughs to catch the sap were made by splitting butternut or basswood trees of from about ten to fourteen inches in diameter and cutting the halves in lengths of about three feet and then hollowing or digging them out with an ax. They were clumsy and heavy, and, instead of being gathered up and sheltered, were stood on end beside the tree through the year, when not in use, and soon became mouldy and dirty. They discolored the sugar and gave it a basswood or butternut flavor.

Old settlers of the country who loved to brag of their hardships and of the rude methods of living in early times, used to glory in telling the story of how they were in infancy rocked in sap-troughs instead of cradles, which indeed did sometimes happen where babies came earlier than sawmills. With a decent pair of rockers they made quite a respectable cradle.

Storage troughs were made by using twenty or thirty feet of the butt of a large basswood tree, flattened on one side and dug out with an ax. The sap was gathered by hand - that is, carried to the boiling place in buckets by men with neckyokes on their shoulders, or in pails without the use of neckyokes. 
Boiling and sugaring-off were both done out of doors, in big kettles hung on poles over the fire. The wood was cut as wanted and used green. The result was black and inferior sugar. An old pioneer would not think the maple sugar of to-day, made by the use of improved methods and implements, was genuine. To him it would lack both flavor and color. Our people sugared-off in the woods for a few years only after I was old enough to go to the woods.

Two little episodes personal to myself are called to my memory by this sugar-bush talk.

When a very small boy I was one day alone with my father in the sugar-bush. Sap was running fast and he was gathering it late. I was left at the shanty to tend fire. He had gone over the bush that day, all except the hemlock-hill route, and started out for that long after sundown and after the evening shadows had begun to fall deep and black, telling me to keep a good fire, that he would not be gone long, and then we would go home. I watched him disappear down towards the little brook with no particular anxiety and turned to the shanty. I stood around in front of the fire awhile, and then sat down on the edge of the bunk. Then I got up and walked out to the woodpile and back. Perhaps fifteen minutes elapsed while I thus nervously occupied myself. The shadows began to deepen and the light of the fire shone brighter and brighter upon the solemn, big maples in front of the sugar-house. The trees began to look vague, doubtful and suspicious. I could not see and did not know what was behind me. I began to think that father had been gone too long, and I went down towards the slippery-elm tree and called, as I thought, quite loudly, but got no answer. Hemlock hill was dark and black. I hastened back to the shanty, but did not care to go in. The solid black 
steam in the back part of the sugar-house was impenetrable. I forgot all about tending fire. I could not understand why father did not come. He had not been gone twenty-five minutes, and his work required an hour.

Suddenly I heard a most doleful, startling noise-a h-o-o! h-o-o! h-o-o! It came from the Pitkin hill and was soon repeated, seemingly nearer the shanty and from the vicinity of the middle route. I anxiously looked towards hemlock hill, but dared not call out again. The noise was repeated louder and louder, and nearer and nearer, and more dismally. I could stand it no longer, but started, looking over my shoulder as I passed the corner of the shanty, and took the left-hand fork, which led out of the woods towards home.

First I went on a sharp walk, but soon broke into a run, which I kept up until well out of the woods, at every step expecting a panther or some terrible beast to light on me with all fours. I was well out of breath when clear of the woods, but kept up a good pace. In the clearing it was not so very dark, but I hastened along. In crossing the bridge over Deer Creek, which was then at full banks, my cap blew off and into the creek. This was a little matter to one who had just escaped destruction from wild beasts, but it added to my worry, for it was my only cap except my church cap, which I knew could not be used in secular business under any circumstances. I began to follow it down stream without knowing just what I hoped for, when Raleigh Fox came along and helped me out of the difficulty by going out on a $\log$ which crossed the creek just below the "ducking-hole" and rescuing it.

I hastened home, which I reached some time before my father. I was unable to satisfactorily explain the affair to mother, who was quite a little worried over my coming first and 
alone, and probably more so from seeing the demoralized condition which I was in. Father soon came home, and, after putting out his team and eating his supper, took me on his knee in front of the big fire-place and questioned me as to what had happened. I told him that I thought he was not going to come back, and that I heard something which scared me. He knew that it was owls that had given me the panic, for he also had heard them. Then he told me what was the punishment inflicted upon soldiers left on guard who deserted their posts. I was not old enough to fully understand and appreciate the joke, but quite old enough to know that I had disgraced myself and that I did not want to go through the same experience again.

When thirteen or fourteen years old, it became necessary that some one should boil all night, and I undertook the job. Birney Huson, a nephew, a year or two younger than myself, stayed with me. We got along very well through the night and kept up a good fire and "boiled in" a large amount of sap, syruping down and taking out a nice batch about twelve or one o'clock.

When daylight came, a boyish curiosity took possession of us to go over to an adjoining bush, run by one George Charnick, to see how he got along. We found that he had also boiled all night and was still hard at work. Having satisfied our curiosity and finished our morning call, we started leisurely for home.

About the time we reached the top of hemlock hill I smelled burning sugar. It took but an instant for me to realize what had happened - the pan was boiling over and the syrup burning. I started on a run, going down the hill by long jumps, and soon left Birney far in the rear. The farther I went towards the sugar-house, the stronger the odor of burning sugar. As I passed the little brook and the slippery-elm tree, the woods 
were black with the strong-smelling smoke, which settled in the hollow. Completely out of breath, I reached the shanty and, looking in through the strangling smoke, beheld the forward pan, every inch of it red hot and apparently a live bed of fire.

I grabbed a bucket of cold sap and dashed into it, and other bucketfuls into the fire under the pans. We had been boiling a long time without having raked out the solid coals from the arch. The fire hissed and sputtered and ashes flew, and the stones of which the arch was built cracked and snapped, but it finally became subdued and cooled down so that I could examine the extent of the disaster. The very hot fire and heavy bed of coals under the pan when we had left it had boiled the syrup down rapidly and burned it completely up, so that there was left but a lot of shelly, scaly charcoal refuse in the bottom of the pan. The pan itself was burned, the bottom warped and apparently completely ruined.

On every side the woods were filled with the strong-smelling smoke. I was mortified and terribly scared. I had never had or seen any such accident, and knew that it had occurred purely through my carelessness and criminal negligence in leaving the house alone. The amount of sugar wasted was eighty or one hundred pounds, which meant eight or ten dollars.

Like other criminals who are the victims of accident, I at once jumped to the vicious conclusion that I must conceal my crime. Birney was also agitated and asked me what I was going to do. It was no fault of his, yet he shared the feeling of shame and humiliation, and asked, "What will grandpa say?" He was as nice and conscientious a boy as ever was born, and I feared that he would not help cover up the affair. I told him that we would not tell, and asked him not to say anything about it. $\mathrm{He}$ made no special reply, which annoyed me all the more as 
I knew his disposition for candor and veracity; but we went to work, I doing the most of it. His heart did not seem to be in it.

We cleaned out the coal and cinders in the pan, rubbed and scoured it down with a brick, washed it out, again rubbed and scoured and washed again, yet the damnable evidence still remained in scales on the rough, burned bottom of the pan, which could not be gotten off or out. Having done the best possible in this direction, I threw the burnt cinders and stuff cleaned out of the pan into the ash-heap at the door and covered it well with the coals and ashes taken from under the arch, filled up the pan with fresh sap and again started the fire.

Then I began to revolve in my mind what story to tell when questioned, as I certainly would be when father came up, which would be about eight o'clock. It seemed as if the smoke of the burnt sugar would never leave the woods. At eight o'clock father came. I did not go out to meet him at the forks of the road near by, as was customary, but was busy tucking up the fire and doing other work about the shanty. He got off the sled and came around the corner of the shanty to the door where I was, and exclaimed, "Whew! What's the matter? What has happened?"

I promptly replied, "The pan has been boiling over."

"Well, I should think so," he said; "I smelled it away down at the edge of the woods. I thought you had burned up the whole batch. What made it rise?"

"Sour sap," I guessed.

"It is too early in the season for that. Did you have any pork?"

"No, sir; it was all gone." I had taken pains that it had gone into the fire.

"Well, why didn't you use cold sap?" 
"I did, but it kept coming up again."

"When did you syrup off?"

"Only a little while ago." I had to say this, for the sap in the pan did not show that it had boiled any great length of time. It was lucky that we had a nice lot of syrup to show, although the quantity was not what it should have been.

These and a half-dozen other questions, not actuated by any suspicion, but right straight to the point, he put to me, and to every one got a good square lie, and every time I plumped out a lie it seemed to make it necessary that three or four more should be told in support of that one. He talked about it more or less all day - about the singularity of the matter - and I helped along with all kinds of suggestions.

It was early in the season and none of the buckets or tubs were sour, although I had told him that I thought some of them were a little off. He did not talk with Birney about it, and Birney, much to my comfort, did not say a word, although he looked pitifully at me as one not fit to associate with.

That, as I supposed, ended it. But a day or two afterwards, before starting for the woods, mother began to question me and asked me what was the matter with that last batch of syrup which came down from the woods. I answered that I did not know that anything was the matter.

"Oh, yes," she said; "it was black and full of scales and ashes, and I never saw such a mass of stuff in any strainer since I have made sugar."

I then told her that the ashes and stuff were probably blown into it, as it was very windy the night we boiled and the door was open most of the time. The boiling over did not account for the black, bitter stuff, so I had to invent another story for her. I answered her three or four questions with as rank lies 
as I had given father. There the matter ended, at least for several years. I was most sorely grieved and troubled over the matter, but never had the least idea of making a confession.

After I grew up and was one day talking with my father about the correct treatment and bringing up of children, I told him the whole story.

"Well," said he, "why under the heavens did you do that? Why didn't you tell me what had happened?"

"Because I dared not. I was afraid. I knew I had done wrong and didn't know what you would do about it."

He whistled to himself and thought the matter over a little while and said, "Well, one thing you did learn, that when a lie is told and turned loose, it takes a half-dozen others to support it;" and from that day to this when I have seen a false witness struggling along to bolster up his first lie, I have said to myself, "I guess you have burnt your sugar."

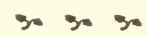

\section{SPRING WORK}

"The flowers appear on the earth;

The time of the singing of birds has come,

And the voice of the turtle is heard in the land."

The work of the early spring was largely affected and controlled by the weather. If warm and dry, so the land could be worked, the grain was sowed early. Oats, barley and peas required to be put in early to insure the best results. Lorraine was not much of a wheat country, although we did raise some very good spring wheat by taking particular pains to prepare and enrich the land. The soil of the farm was clayey and 
heavy, and a backward or wet spring delayed sowing, and sometimes a crop was badly shortened thereby.

We had but one team, with sometimes an extra horse, and they were pushed for all they could do in the spring-time. Plowing, dragging and hauling manure, with an occasional call to draw logs onto the log-way of the mill, and draw lumber for sticking up so as to clear the board-way, and such trips to Adams and the Manor and the "Huddle" as necessity required, gave the horses a hard spring's work. The roads and the wet, clay soil upon which they had to work were against them.

My brother John for quite a time had the responsible position of driving and doing the team work and taking care of the horses. He was older and could handle them better and more safely; but when he got tired of that branch, or was called to work in the sawmill or do something else, I was substituted, and thus early learned to do anything that could be done with horses. When eleven years of age, and before I could put a plow in a wagon, I plowed both old land and green-sward, and then thought, and still think, that I did it well. At thirteen I drew logs from the woods to the mill, loading alone onto the sled big logs that two grown men could hardly handle. This was done by rolling or drawing them on with the team - quite a dangerous business unless one knows just how to do it and is extremely careful. I was quite a stout, wiry boy at thirteen and, of course, was proud to do a man's work.

The days of spring plowing were long ones. The team had to be fed at daylight and must be cleaned before breakfast, ready to go to the field. There was an hour's nooning for dinner at twelve, and about one-half hour for supper at five; then we went back to the field until sundown or later. The endurance of the team was the only question considered. 
Holding the plow after a smart walking young team was no boys' play; when its point brought squarely up against a solid concealed rock, if you hung to the handles your feet went off the ground and perhaps way up in the air; if it struck a glancing blow against a big stone, very likely the handle took you in the ribs and knocked the breath nearly out of you, while the plow jumped out of the furrow, making a bad balk in the work; then it must be pulled back and set in again. This made the horses nervous and fretful and caused more of the same or worse work. The disagreeable features of cultivating stony, rough, inferior soil, sent many a Jefferson county boy West.

Our land was originally very stony, and there were parts of it used only as pasture where you could jump from one great rock to another for rods and rods, and I frequently tried the experiment of going after the cows, in the upper pasture by the creek, without touching my feet to the ground. Quite a part of the land used for meadow and plowing had been cleared of the stone, or at least such as could be dug out and removed. Some boulders too large to pry out were sunk. On others a fire was built and water thrown on, causing them to crack up so they could be taken out. This was father's safe and inexpensive way of blasting without powder.

The farm was in no sense a grain farm, yet we always raised considerable grain - at least enough for our own use, and some to sell. It all had to be sown by hand and dragged in. Grass seed was "bushed" in by hauling over the ground a long, heavy, sprangly young beech or birch tree with the limbs so lopped by a blow from an ax that did not cut them off, as to draw along flat on the ground. A cast-iron plow, a solid twelvetooth square drag, with teeth made of one and one-quarter inch iron, and a log roller was the outfit for putting in grain. 
The winter's accumulation of stable and barnyard manure from forty or fifty cattle was large. It was drawn to the fields that were to be plowed each spring, as there was time to do it. If we were going to plow the field immediately, we spread it from the wagon. If it was to lie a few days before plowing, it was dumped in small heaps, so that it should not lose its strength by drying up or evaporation before being plowed under; then, when ready to plow, it was spread evenly over the ground. This spreading could be and was done while the team was resting, but the plowman never liked that arrangement.

Whether or not the plowing under of this fertilizer was the best practice, I do not know. Farmers disagreed upon the question and argued it earnestly among themselves. We were simple farmers, not "agriculturists," and we then had no agricultural bureaus to tell us how to farm it, and possibly, in our ignorance of scientific methods, did not follow the best. Which was best doubtless depended upon the kind of soil and other surrounding circumstances. We walked by our own lights and followed the suggestions and teachings of our own experience. At any rate, we cleaned up the barnyard, got rid of the manure, and obtained good results, if not the best. We thought we were doing all right and, while we had not the advice of agricultural professors, commissioners, inspectors and superintendents of experimental farms to tell us how to properly till the soil, we got along quite as well as those of the present generation who have these advantages, and better than those who farm it mostly with their mouths, in grange halls and farmers' institutes. If we lost the supposed benefits and assistance of these public officials, we did not have to pay them their salaries. Our taxes were five or six dollars a year, and we paid 
our debts and mortgages when due, and had plenty of everything we needed - at least thought so - and were satisfied.

" $\mathrm{He}$ is never poor

That little hath, but he that much desires."

But I must not leave my work to talk theories; that has beaten many a man besides the farmer. We plowed the fertilizer under and got good grass and a sure seeding. Hauling manure was hard work for the team, as we loaded heavily, and the narrow-tired wagon would cut into the wet, clay soil, making great, deep ruts, which soon required taking a new track. The drawing was, largely, to the upper meadow - all up-hill work. It took several days' work of a team and two men, and was sometimes hurried by borrowing a neighbor's wagon and having one loaded while the other went to the field.

There was muck on the farm, but we did not use it to any extent. That we were not in great need of fertilizer and did not, perhaps, realize its value, is pretty strongly shown by the fact that the farm in its early days had the refuse heaps of two extensive potash establishments, one of which, after seventy-five years of abandonment, is just being utilized. The purchase or use of fertilizer other than that made on the farm was not thought of.

When hay was stacked out, or when it was so plenty that it was thought desirable to feed and waste as much as possible, we used to feed some of it on the frozen ground and snow, in the meadows adjacent to the barns. The cattle would eat more in the open air, where they could drive and hustle one another around - just like mankind, each trying to rob the other and get the whole of it himself. The feeding ground was changed about, so that as large an area as possible would be enriched. The manure thus scattered would certainly not have to be 
shoveled from the stables or loaded and drawn to the fields; but it required considerable work in the spring, before the grass was much started, in breaking up and scattering the dry, flat cakes of hardened manure, which if left alone would dry up, bake down and injure the grass, rather than help it, but if broken and scattered around, it dissolved and made a nice, even top-dressing. To do this, a tool called a "dung-knocker" was used. It was a square, hardwood mallet, having edges so beveled as not to gouge the ground, with a strong handle about four feet long. With this a man or strong boy could strike the hard, flat little heaps so as to break them fine and at the same time send them flying for rods. It was considered very funny work by the boys, particularly if there were two engaged, so as to compete on either long shots or wide scatter. It was a farm sport of great utility, and a muscle developer which far excelled golf. I think it was more interesting than croquet, which it particularly resembles.

It is a well-known fact to those familiar with this old farm practice that the "retired farmer" was the first to become stuck on croquet, and, generally, was the first of the male persuasion to appear on the village green with his knocker or mallet. Indeed, through a sort of evolution or Darwinian development, many a well-known athletic sport is but a modified outgrowth of an early attempt to combine work with pleasure.

The so-called improved methods of modern farming do not include this particular work - at least I have never seen it referred to in the reports of official agriculturists; but I did see, at a farm mortgage foreclosure sale, a two-hundred-dollar manure pulverizer and spreader, which helped bring its unfortunate owner to grief and called to my mind the much simpler method which I have above described.

Between times, the fences were fixed up and the cattle 
turned to grass as soon as it could be done, and the garden made and planted. Corn and potato planting next came on.

The potatoes were generally planted first, on old, mellow ground, and, where the ground was rich, brought a great yield, if they had the good luck not to be struck by rust or rot. I have helped pick up potatoes on the side hill back of the coopershop which yielded at the rate of four hundred bushels to the acre. They were big, red, coarse ones, of which I do not now recall the name. Some of them weighed four pounds. They were worth six cents per bushel, and no market. Most of them were fed to cattle and hogs, after being boiled and mixed with a little grain, pumpkin and corn-meal. For our table use, "Pink Eyes" and a long, white potato, called "Bone Potato," were the favorites.

We were not in a corn country, neither was our land corn land; but we always had from two to four acres of pretty good, small, yellow corn of an early variety, which made excellent meal for table use and good feed for cattle. Forty bushels per acre was a big crop. A western farmer would not think that number of acres worth mentioning, but we were very proud of it and made a great fuss getting the corn land ready. At first we used to think that only newly cleared land or old plowed ground would do for corn, but later discovered that it would do quite well on sod. The corn land was usually the last of the spring plowing. Good corn, however, we could raise only by manuring in the hill. This was a slow, tedious job, but it brought good corn. A compost for the hills was prepared by mixing the soil of the hog-pen and the guano of the hen-house with a quantity of horse-manure and ashes. The horse-manure was the principal item, and was thrown under the big hoghouse, which stood up from the ground, a year in advance, to 
become mixed and saturated with the hog-pen product. At planting time this mixture was drawn in a wagon-box to the field, where we took it with large, flat or scoop shovels and carried it from hill to hill, putting a good, big handful of the mixture in each hill, and poking it off the shovel with the bare hand. It was not the sweetest scented work in the world, but made a sure crop.

The pumpkins were planted with the corn, and made good feed for the cows and hogs in the fall, to say nothing of the famous pumpkin pies.

Between planting and hoeing there were a few days in which no farm work crowded. These were utilized, among other things, for repairing the roads and thereby cancelling the road tax. The pathmaster set the time and "warned out" those assessed.

To the young men and boys this was the jolliest job of the year, and they made it a kind of play spell, instead of serious, hard work. All calculated to have a good visit, compare notes, tell stories and gossip to their hearts' content. They had been busy all through the spring, each with his own urgent work, and had seen little of one another, so this "working on the road" might be called a sort of round-up and review of the spring business and news.

The pathmaster kept the time and credited it in days' work. A man or big boy who could hold a plow or scraper counted a day; a small boy, one-half day; a team, wagon, plow and scraper, one day each. They came late and quit early. If it was hot or the pathmaster was very clever, considerable of the time was spent under some convenient shade-tree beside the road. While the time went on and the men and horses rested, the wagon, scraper and plow went right along working out the 
tax. The young men plowed and scraped or drew gravel and dirt, bragged and showed off the smartness of their teams and themselves. The old men used hoes, on which they leaned and with which they leveled down the uneven work left by the scraper and wagon dumps, and exchanged reminiscences of old times. Exhibitions of smartness were frequent in rapid scraping, shoveling and drawing dirt or gravel, but it did not last long.

They succeeded in making much good road almost impassable for the next six months, and they improved a few bad places. They tried to so arrange that all got their tax worked out at the same time. It was a pleasant job and soon over, and the pathmaster closed it himself by marking off everybody's tax who had cheerfully turned out and helped make the occasion a pleasant one, without being too finicky about fractions of days. No one was rigorously treated in computing work done, except the fellow who paid only a poll tax. He had to do a good, square day's work; no plow or scraper could lie beside the road and work his tax. Then, as now, bare-handed labor was the victim of merciless capital.

Squire Norman Rowe was a justice of the peace and the oracle of the town of New Haven. A pathmaster called on him to fill out a return to his road warrant. The squire filled out the blank form, closing as follows: "And I do most solemnly swear that the days' work set opposite each man's name on the within warrant has been actually and faithfully performed." The pathmaster read it slowly and thoughtfully.

"Sign it there," says the squire.

"I do not just like it," said the pathmaster.

"It is the usual form," said Squire Rowe. "Do you see where it can be bettered?"

"Yes, I do," was the answer. "Make it read this way: "I 
do most solemnly swear that the days' work set opposite each man's name on the within warrant has been actually and faithfully performed as work is usually done on the road.' Don't you think that sounds better, Squire?"

The hoeing is next in order. To be sure, there was not much of it, but it had to be done thoroughly. The rows were planted so that they could be plowed out and cultivated only one way. Corn, potatoes and beans were gone over at least twice with the hoe. "Hilling-up" was done at the last hoeing. Sometimes the weeds, grass and stones would be so thick that it was slow work, and the field had to be gone over three times. It was work in which skill, strength and quickness of motion told. Each took a row, and when a turn-about was made the outside man took that which was next to him, and so on. This insured each one getting a fair deal. There was a great difference in the rows, some having more stones, weeds and grass than others through a part or the whole of their length. This originated the expression, "He has a hard row to hoe," or "He has the boy's row"- a boy generally thinking and claiming that he had the hardest of it. In our work, when we were small boys, father, to keep us along and prevent us from getting discouraged and falling by the way, would take two rows to our one, or he would occasionally hoe a few hills on the boy's row.

We sometimes changed work in hoeing, when a neighbor's field was a little earlier than ours. Then there was likely to be a little fun in bragging and racing. On farms where hard cider or other liquor was used, occasionally the corn would receive more damage than benefit by these contests. I was told of one man who used to get great work out of a gang of Frenchmen by going ahead with a jug of whiskey and setting it down at the end of the row and leaving it there until the gang reached it, then car- 
rying it back to the other end, and so on all day, or till the jug was empty.

My brother-in-law, Willard Huson, was known as a thorough, driving and successful farmer. He was held up as a pattern and example to all boys, young men and others who desired to be considered first-class workmen. $\mathrm{He}$ was, in western parlance, a "rustler," and had the respect and admiration of all the neighbors on account of his good judgment, energy and success.

He was changing work with us one week in June, and we were all hoeing on the side hill. It was blistering hot weather, and a scorching sun beat down with great intensity. To hoe with Willard was a great honor to a boy who could keep up his row, and I was doing it in good shape.

He had his shirt-sleeves rolled up nearly to his shoulders. It was his custom, and he had worn them so from early spring. His arms were muscular, brown and hard. I felt that to be a man, or have any standing as a farmer, I ought to roll up my sleeves also; so I did. My arms were white from my wrist up, and the skin soft and tender as that of a woman. We were working hard, and the hot sun was pouring down on us without mercy. At noon my arms began to look red, itch and smart, and by night they were badly burned and began to swell, but I said nothing, for I was making a man of myself rapidly, without the advice or help of any one. I went to bed without making any complaint or report of their condition. By midnight they ached so I could not sleep, and before morning I was almost crazy with pain. In the morning the skin felt thick as a board, and I could hardly bend my arms.

Mother discovered the trouble and, calling me a foolish boy for having burned them, rubbed them well with Mustang lini- 
ment, which was then having a great run at our house for all ailments of man and beast. The liniment had something in it that stimulated the inflammation and made my arms still hotter and sorer, but I went to the cornfield and began work again, thinking to tough it out. My arms grew worse and worse, and the pain made me sick. Willard told me to put down my sleeves, and that I should have begun in March if I wanted to go bare-armed. The pain was so great that I soon had to quit and go to the house and stay there for two or three days. The arms became more inflamed, cracked and peeled in some spots on the upper side, making quite angry, deep sores. I had to sleep on my back, with my arms wrapped in cotton and greased rags. I was not only ill and feverish, but chagrined and mortified by the blackguarding which I got from the hired man ard the younger folks about the premises, who were always on the watch for a good joke or take-down upon me, whom they considered a boy that needed frequent "budding back."

I carried the scars for years, and the lesson learned still lasts - not to be too anxious to get out of one's own class or too prompt in imitating the apparent virtues of others.

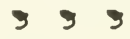

\section{VACATION}

"If all the world were playing holidays,

To sport would be as tedious as to work."

With the hoeing out of the way, there were sometimes a few days in which no special work was pressing. But it was not a vacation as now understood, for there was always the milking and dairy work seven days in the week, except that no cheese 
was made Sunday. There were fences to be strengthened and repaired against the dry season, which makes cattle hunt the holes or weak spots in the pasture fence; buildings, barns and stables required repairs and arrangement for the fall and winter, before haying; slab-wood to be drawn to the sugar-bush and house; post-holes to be dug, and new fences, gates and barways built; lumber to be stuck up; old rocks, against which there were standing orders for destruction and removal, were attacked and destroyed; great stone heaps hauled from the meadows to where they would be needed for wall; stone was quarried from the flat rock beds in or near the creek, which at other seasons were too deeply submerged to be got out; ash and spruce trees were to be got out of swamps not traversable at other seasons; hoop timber and hoop-poles to be cut and backed out of the woods and swamps, and hoops to be racked for future use; flower-beds to build and cultivate, and garden and horticultural work to do, for which time could not be spared at other seasons; the repairs on the milldam and ditch, and the cleaning out of the stone and gravel from the mill tail-race and flume. There was underbrush to be cut, and bushes and weeds in fence-corners to be mowed; lumber to be drawn, haying and harvesting implements to be overhauled and put in order. If a visit had to be made, this time was usually selected as most convenient for the same. In short, this was the time to do anything and everything that had no other special time for its performance, or had till then been neglected. These and various other things filled the time between hoeing and haying, so that it did not hang heavily on our hands, and was our summer vacation.

The eight-hour law had not then been proposed. There were no half-holidays, and no one watched the clock or calendar. The sun as it came over Fox's woods told us when to 
begin; and, as it lined up on the old noon-mark, called us to dinner; and, with its falling behind Job Lamson's hill, gave us permission to quit for the day. Organizations for the purpose of regulating or preventing work had not been heard of ; industry and close application to business were highly commended and popular, and good standing in Lorraine society did not then require going to Saratoga, the Islands or the seashore for vacation. The circus at Adams and the Ellisburgh fair at Belleville were considered the proper thing, and about enough in the line of summer rest and recreation.

The various kinds of work crowded into these midsummer days were enjoyed, at least as varying the monotony of regular season's work. We did not know that we needed or ought to have a vacation, and probably were as happy and got along quite as well as those who live in these more rapid times, who, hoping to make themselves popular, are obliged to borrow money each summer with which to hire high-priced board shanties, called "cottages," and defray other expenses at the summer resorts.

\section{3}

\section{HAYING}

Haying was our most important harvest, and the crop was of more value than any other that we raised. From the dairy came the principal income, and upon the amount and condition of the hay crop its success depended. The condition of the meadows was anxiously watched from the time the snow went off until haying time. The grass was liable to damage from the freezing, thawing and heaving of the clay soil, particularly when the snow was light or where it blew off the meadows. It was also injured by drought or excessive wet. 


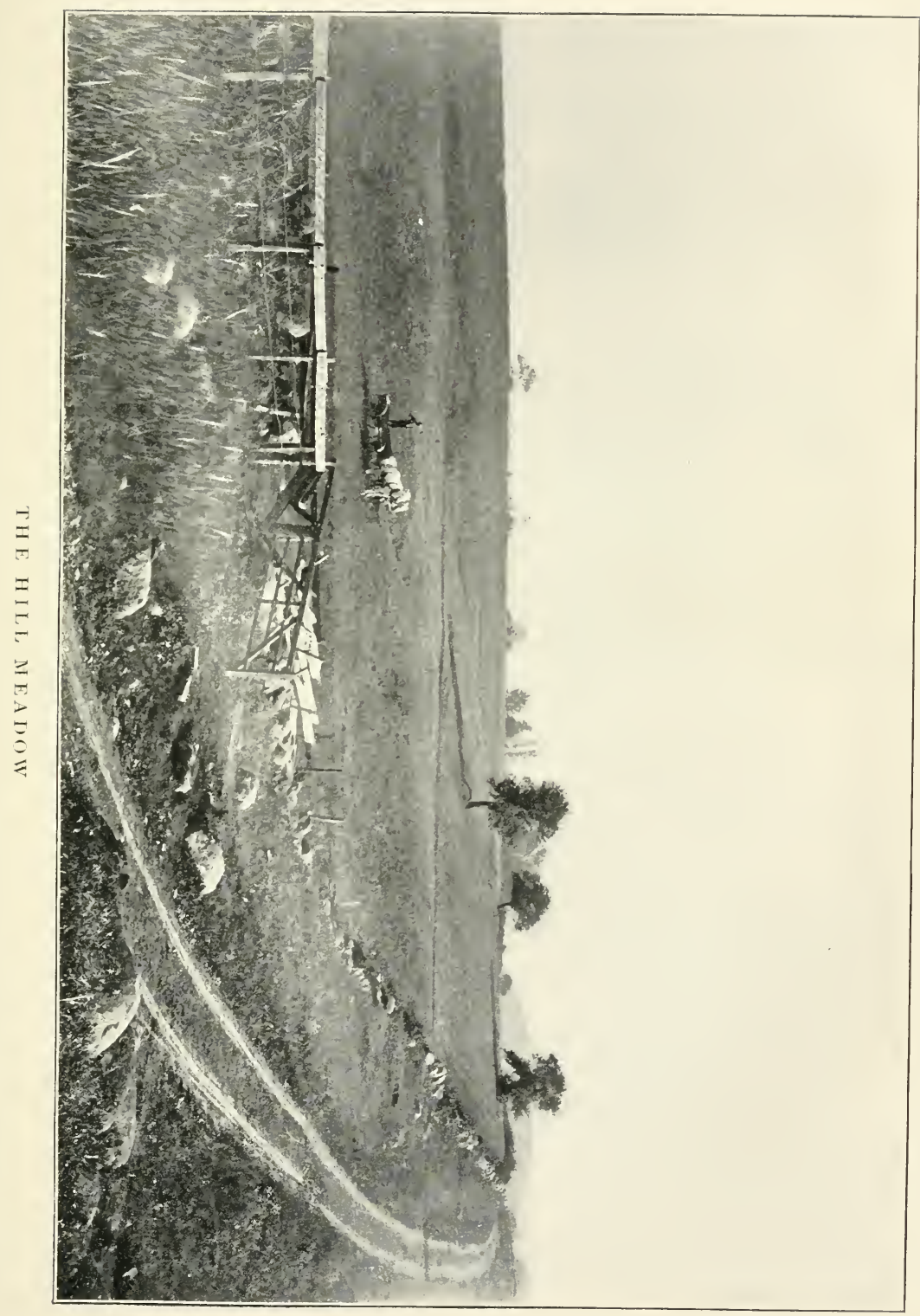




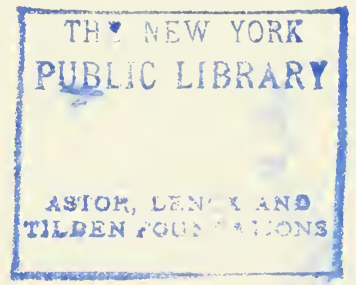




\section{OLD HOMESTEAD}

We generally began immediately after the Fourth of July. If the grass was late we began moderately - that is, with little or no help except the regular hired man, if we had one. We always mowed the lower orchard and lodged grass back of the barn first. The orchard was a good place to begin, on account of the shade, and the heavy grass back of the barn must be cut early to be of any value.

Very many eggs were found in this heavy, lodged grass, where hens had stolen their nests. The old hens got tired of laying eggs all the winter and spring to have them stolen out of their nests day after day, and so the cute old birds left the barn and made their nests in the deep, tangled grass, in the strong hope of posterity, braving all dangers of skunks, weasels, minks and other vermin, hoping to bring off a brood of chicks before discovery; but their hopes were dashed by the swish, swish, swish of the long, sharp scythe, which meant decapitation or immediate flight, and after having kept still as death for two or three weeks, they ran away, screaming and cackling, leaving their embryo families, who had already begun to hammer their white prison walls, to perish without ever seeing the light.

The first days were apt to be the hardest. Mowing and pitching hay brought into use and made sore and lame a new and different set of muscles, which it took several days to harden to the work. The hands were blistered where the nibs of the scythe-snath or handle of the pitchfork found spots not already hardened or calloused by other work.

Haying required extra help, and from two to four men were hired by day's work, at one dollar per day and board. They were tough, strong men, able to mow and pitch all day without weakening, and it was hard luck for any weak or lazy man who got into the gang. Father used to hire some Frenchmen from 
the settlement in the east end of the town, who were extra good hands and could be easily paid, as they always wanted pork, flour and sugar, of which there were large quantities in the cellar and storeroom.

The ripest grass and that which was likely to lodge was cut first; at least, this rule was adhered to as closely as it could be without jumping around too much. Beginning with the lower meadow, next the big upper meadow, called the "hill meadow," we usually finished up at the old place across the creek, where grandfather first settled and which our brother Gilbert owned when he died.

The day's work was usually commenced by mowing around a field or piece of grass of such size that it could be "downed" before dinner, and raked and cocked up in the afternoon, or drawn to the barn if dry. Sometimes, in order to have all that was cut in a body, the mowing was conducted by what is known as "turning a double swath" and mowing backwards and forwards on each side thereof, or in "carrying" the swaths, which meant mowing through to the end and walking back.

The men mowed at intervals of three or four feet each, a good mower cutting a swath of about four and a half or five feet. They kept stroke in swinging the scythes, and there could be no lagging. The only dead-beating was by mowing narrow or "lopping in and out"- that is, striking in high at the heel and letting the scythe come out high at the point - a vicious practice not allowed by any good farmer. They could only make time by making false motions in whetting or sharpening the scythes.

The leader gave the stroke and it had to be kept by all. Mowing out of stroke is like walking beside a person out of step, and even worse, because the man out of stroke may hit the 


\section{OLD HOMESTEAD}

heel of the next man's scythe with the point of his. If any mower showed a disposition to crowd up and throw the cut grass from his scythe onto the heel of the scythe of the man next in front, it was at once taken as a challenge or an insult, and unless he was an extra good workman he was sure to get the worst of it before night, for everybody laid for him all the rest of the day, whenever they could get him at a disadvantage, and he soon found that he was being driven or left whenever he got into a heavy, hard spot, or, if pitching in the afternoon, he was quite likely to find himself buried in the hot mow by the man pitching off.

Knowing how to keep the scythe good and sharp was the first qualification of a good mower. No one, however strong, could do good work with a dull scythe. They were ground from time to time upon the grindstone in the old sawmill, which ran by water, but the edge could not be long carried unless one was skillful in the use of the whetstone. The music of the whetstone on a long, high-tempered scythe is the sweetest in the world, and the cling-clang, cling-clang, cling-clang, cling, as the mowers rapidly drew the stone over the edge of the scythe, first on one side and then on the other, from heel to point, as it came from the clear air of the meadow before breakfast or after supper, was a sound to rejoice the heart of a thrifty farmer.

As the grass was mowed down by the men, at least as soon as the dew was off, we boys had to spread it or shake it out over the ground to dry. If very heavy, after drying awhile it had to be turned. This was considered light work, specially adapted to boys. Indeed, the girls sometimes helped, when men were scarce or could not be spared from the mowing or pitching.

The ambition of every boy was to get beyond being good only for a spreader and be allowed to take his place with the 
mowers. It was an advancement and recognition of manhood, to reach which he would work beyond his strength and punish himself severely. Of course, John got into this "man " class first, and the spreading became still more distasteful and disagreeable to me. Instead of growing better at it I grew worse, throwing it in chunks and heaps, and when reproved, claiming I could do it no better and keep up. This occasionally resulted in father sending John or some of the lightest mowers to help me out - a shift they enjoyed, as it rested them. John was a good mower, and always could better sharpen his scythe than $I$. He was what was called a natural, easy mower, but at his age, and even before, I was fully as strong as he and more conceited. Nevertheless, the fact that I mowed narrow and lopped in and out too much, caused me more frequently to be sent to the house for water, to catch the horses and bring them from the pasture, to turn the cheese, or on other errands which some one had to do. These special details were very acceptable about half-past ten or eleven o'clock.

We mowed lowery days and in "ketching weather," and when we got too much down and the weather was fair, we drew it into the barn forenoons as well as afternoons. Very frequently more would be cut than could be cured and drawn the same day or before it got wet - a thing which gave rise to that homely but significant farmer's expression, with reference to self-imposed difficulties, "He has got down more hay than he can get up."

The afternoons in fair weather were usually devoted to raking and drawing the hay to the barn. During my boyhood days and while I remained on the farm, the raking was done with an oldfashioned revolving wooden rake. It answered the purpose very well, and was better for the meadows than the wire-tooth rake, and with it and a smart walking horse a man or quite a small 
boy could shove an acre of hay into windrows in a very short time. Then he could turn and go lengthwise of the windrows and bunch it in great heaps for pitching, which we called "tumbling."

In the early days of farming, when the meadows were rougher and before the invention of any kind of horse-rake, the raking was all done with the old hand-rake of the same pattern as that used by Maud Muller when she learned "the saddest words of tongue or pen." When the hay was raked together the team with the hay-rack followed - one man, and sometimes two, to pitch on, and one on the load. The scatterings left by the pitcher or dropped from the load were secured by the man or boy who raked after, throwing what was thus gathered up in front of the pitcher, or throwing it on the load with the rake. The latter course required an expert raker, and required the use of the feet as well as the hands. Raking after was lively business, particularly if one boy was set to do the work where it really needed two. He had to keep up as the load moved on, without reference to the raking after; then, in the language of Casey's tactics, it became "one time and two motions." They went rapidly along one windrow and back on another until they had a good, square load of a ton or more on the rack, which was driven to the barn to be unloaded or pitched off. It went into the big bay, if good and dry; onto the scaffolds and into the hay-sheds around the old barnyard, if not quite so well cured. Pitching off was all done by hand and was hard work, requiring a good man or very strong boy.

If the weather was threatening rain and there was hay out, the drawing was not discontinued until dark. Sometimes we were wakened from our sleep in the morning by father, who would get us out at three o'clock to hitch up and draw hay be- 
fore breakfast, to prevent its getting wet. It was customary to rake and cock up the hay to be left out all night, to prevent damage from dew or possible rain.

Drawing hay towards the last of the season required it all to be pitched over the big beam or high up in the barns, and pitching off and mowing away were then much harder than at the beginning. Mowing away hay in the peak of the old barns and sheds was hot, tiresome business. The heat from the hay which had been exposed to the sun all day and the choking dust coming from the same were very oppressive. The rake-after boy was apt to be drafted as a helper in this work, and always put way up in the peak of the barn or end of the shed, farthest from the air and light.

Mother always helped us out with refreshing drinks of various kinds, which to the panting, sweating workmen were very acceptable. A favorite beverage of hers, called sweetened water and vinegar, was made by taking cold well water, maple sugar, ground ginger, with a little spice and plenty of vinegar, which was mixed and stirred in a huge pitcher or pail and brought to the barn, which was but a few rods from the house, for the men's use before and after pitching off every load. It was a good, safe, nutritious drink, and the men who drank it could work much longer than those who drank only water. She used also to fix up milk and water and other kinds of fancy drinks that were good and tempting, and usually about the beginning of hoeing made a large barrel of root-beer from fermented hops, roots and other stuff, in the concoction and brewing of which she was very skillful. It was a very palatable drink, and did not carry alcohol enough to intoxicate. Its only fault was that it did not last.

Sometimes the last load of the day was allowed to stand 
over night on the wagon if it was very late - a thing which was made necessary by the fact that there was milking to do, or to help do, after the work was done in the field. This, however, could not be permitted if it was Saturday night, especially in the earlier days which I remember, for at that time there was but one wagon on the farm available for going to meeting, and that the lumber wagon used for drawing hay and for all other purposes.

There were some features of haying that interested a boy. At the beginning there was a good chance to mow into a nice patch of dead-ripe strawberries, the very sweetest and finest flavored ever seen. Around the fence-corners of the back lots we found occasionally a black raspberry bush which had escaped the scythe or been exempt from the ugly little bush-hook. Finding hens' nests in the deep grass and fence-corners, wasp and hornet nests on bushes and trees, and birds' nests here and there, was common; but the thing which made lively sport, and furnished a luxurious treat as well, was the finding and breaking up of bumblebees' nests. There were plenty of stone heaps, little and big, in which the bees built their nests and stored up their honey. If the mowing did not disturb them, we were sure to do so in spreading, for we never passed a stone heap without rapping on it with our forks, to see if any bees lived there. If they did we were sure to hear from them, and for our rude impudence we sometimes got it in the neck, over the eye, or under the ear, and temporarily beat a retreat. Providing ourselves with long wisps of green hay - wet, if possible - we waited for the bees to go in, and then attacked their little stone fortress, wildly swinging the hay around our heads and with it beating to death every bee that came out of the nest. It was easy to do this if one were quick enough to hit them before they took wing, 
but if three or four of them got fairly in the air and charged you in front, flank and rear, they were apt to make it hot for you. Having subdued the spiteful little swarm, we carefully broke in and curiously uncovered and secured the comb which held the honey. No honey ever tasted so sweet to me as this bumblebee wild honey, and when at Sunday-school I first heard Philo Brown, my teacher, explain as to the experience of John the Baptist in the wilderness, when he ate nothing but locusts and wild honey, I rather envied the old saint the honey part of his diet, though not hankering for the locusts, which Philo told us were grasshoppers.

When the land was newer and more productive, a part of the hay had to be stacked out, but it was a wasteful practice and avoided if possible. I can, however, remember when we filled all the barns and hay-sheds on the home place and both the big and the little barn over the creek, and stacked out hay at both places. Cattle were then wintered in the old barn across the creek, so as to feed out the hay cut and stored there. No one then expected to see the hay crop dwindle as it has.

Father did not use a mowing machine on the farm for many years after its general introduction. The land was rough and stony, and the help of the mowers was needed in pitching and handling the hay after it was cut. He figured it to be cheaper doing haying on a rough farm by hand than to use a hundredand-fifty-dollar machine, which required constant repairs. With good help, hay was cut and put into the mow for fifty cents a ton.

In the year 1858 , and after my brother and myself had practically left the farm for good - or for bad - we were home from school, helping father do his haying, a practice we kept up as long as we could. It was Thursday night, and the haying was 
nearly done. We wanted to finish Friday, if possible, and go fishing Saturday with Albert Betts, a young schoolmate who was coming from Pulaski for that purpose. He intended to take us back with him as school opened the next Monday.

The hay was all cut except four acres of the cradle-knoll meadow next to Elder Wilcox's line, which was new-seeded timothy grass, standing up tall but not thick - perhaps a ton and a half or so to the acre. John and I and Leander Fox, a neighbor's boy who worked that season for father, were the working force. At half-past three mother called us, and we went to the field. We hung our scythes well out so that we could mow wide. Father had ground them nice and sharp the night before. We started in at a good, sharp clip and kept it up, carrying our swaths, which enabled us to get a breathing spell as we walked back. At half-past six we had the four-acre field all down, just as mother came out on the great big rock under the cherry tree and blew the horn for breakfast. As soon as we were through with breakfast we went back to the meadow and opened up the two or three acres of cocked-up hay which was cut the day before, and at half-past eight or nine o'clock began drawing.

Father did the raking and "tumbling" with the horse-rake. Leander and I pitched on, and John, who was always the best at that, did the loading. Raking-after was left to be done with the horse-rake next day. It was the last of haying, we were hardened to it and had our second wind, and hustled all day. We changed off in pitching and mowing away, so as to utilize the very best efforts of all.

Mother caught the spirit of the rest, and never failed to have a big pitcher of cold drink of some kind ready as we drove in and out. Nooning was made short, and the team went from the barn to the meadow every time on a good, sharp trot. At dark 
we had the last and tenth load on the big barn floor. We had done enough for one day. We did not pitch it off, but got to bed as soon as the chores, which included helping milk, were done.

Albert Betts came as agreed. The horses, which were usually sent to pasture summer nights, were kept in the barn for an early start, and at four o'clock the next morning mother called us down to a good, hot breakfast and had already put up for us a big pail of luncheon, and by five o'clock we were on our way to the "happy fishing-grounds" above O'Neal's mill. We took in a mile of Deer Creek (the upper part of which is now called the "Raystone," being a corruption of Horatio Stone Creek), and before night had our four baskets and our pockets all jammed full of nice, sizable brook trout.

For another such day's fishing I would be glad to undertake a hard day's work, but doubt if I would be able to get there, if mowing an acre and a third before breakfast and helping pitch ten tons of hay both ways was the condition.

\section{3}

\section{HARVESTING AND THRASHING}

Although we did not raise much grain, yet there was quite a variety - usually all that was required for the use of the family and the farm. Two or three acres of spring wheat, eight or ten acres of oats, three or four of barley, with peas and a patch of buckwheat and some mixed grain for feed, was about all there was of it.

Soon after haying, the early grain began to ripen and required 
cutting. This was done with the scythe or cradle, as circumstances seemed to require. All of it that could be got into the barn was put in, which was quite an amount, as the hay in the great bay had settled and left plenty of room at its top. The scaffolding immediately over the barn floor was always left for grain, and by taking great pains a large amount could be stored upon it, filling from the scaffold away above the purlins, clear to the peak. If it could not all be put in the barn, stacks were made by the door, which would be convenient to the thrashing machine. It was impracticable to thrash as it was drawn from the field.

It did not require much extra help to do this harvesting, as the hired man and the boys could do the most of it, as it ripened gradually in the same order in which it was sown. If the grain was very short or thistly, it had to be mowed and handled loose. If it stood up fairly well and was free from thistles, it could be cradled and bound. This was nice work, but it required considerable beef and bottom to swing the heavy, old-fashioned straight cradle. Later on, a lighter and easier working "muley" cradle was purchased.

Raking and binding was interesting and pleasant, although backaching work. It was quite a knack to be able to make the bands, draw them around and tie them tight. Some would stoop down and put their knees on the bundle, but the good binder drew up and bound his bundles without doing this, and could bind as fast as a cradler could cut it. Like swimming, the motion of making a band, when once learned, can never be forgotten or lost. Cradling requires a man very strong in his arms and chest. Some were very proficient in the work and could do it very rapidly, cutting five or six acres in a single day. I was not one of them. 
When cut the grain was bound into sheaves, which were collected and placed in shocks of a dozen or more, in conical heaps; heads up. Then one was bound near the end instead of the middle, and the longer part opened up and placed on top of the conical pile, making what was called the "cap-sheaf."

In very early times the little grain which they raised was all cut with the old-fashioned sickle. A man could cut but a littleperhaps a quarter of an acre or so in a day. My only experience in attempting to use one was where my father was reaping some lodged grain which could not be cut with a cradle. Instead of reaping the grain I reaped a big gash in my leg just below the knee. The edge or teeth of a sickle make a peculiarly ragged, nasty cut, and I yet carry the scar.

Thrashing was done as soon after the grain was in the barn as the thrashing machine could be procured. These were expensive machines and not common, there being but few in town, and they went around from one place to another as required. When they were brought into a neighborhood, the thrashers always tried to do all the work in that vicinity, so as not to lose time going and coming.

The first style of thrashing machine which I remember was the old sweep power machine. It was owned and operated by Amos and Asa Randall, neighbors who lived a couple of miles below. It took four span of horses, hitched to the long arms of the sweep, which went round and round and by means of cog-wheel gear drove the band-wheel, which by belt communicated the power to the cylinder. A man stood on a platform laid on the revolving arms in the center of the horses, and watched them that they all pulled even and kept up the proper speed. I remember well how I envied Asa Randall as he stood on this platform in the center of the revolving horse-power and 
cracked his whip and sang out to the teams. To me it was a position much to be desired, even more to be envied than any I knew of, except that of a stage-driver.

The cylinder and concave, with teeth through and between which the grain was fed, was a coarse affair, but answered its object very well. No separator or cleaner was attached. A man stood behind the cylinder as the thrashed straw was cut and mangled by the ugly teeth of the rapidly revolving cylinder, with chaff, dust and smut coming through in great puffs and striking the floor at his feet. With a swiftly moving rake he separated the straw, which was passed to another, who pitched it farther back. Others carried it to a stack outside or helped to dispose of it promptly in some way. As the grain accumulated it was raked back and thrown into a corner of the barn floor, to be cleaned up later.

It was nasty, choking, disagreeable work. One's face would soon look like that of a negro, and his eyes and nose were fairly closed with dust, dirt and sweat, but there was no let up. The bundles were thrown down from above and the band cut with a slash of a long, sharp knife and passed to the feeder, who run them in, bundle after bundle. Loose grain was pitched onto the platform beside the feeder, who shoved and pushed it into the cylinder as rapidly as the power would permit. There was no chance to shirk. Every one had to do his part and keep up. Notwithstanding my boyish admiration for the driver, the feeder was the master of the situation. When he turned round, raised his leather-mittened hand and shook it, the horses slowed up and stopped. No other supreme authority was recognized in the barn.

It required a big gang to work one of these machines, and between the horses and the men required to run it, they would 
eat up considerable of what they thrashed. The advent of the thrashers and their care and feeding was a great event on the farm and death to the chickens. It was customary with the farmers' wives to have great pots of fricasseed chicken for dinner whenever the thrashers came. I remember once hearing my mother make an apology to Uncle Christopher Huson, who, with Lafe Lanfear, was an itinerant thrasher, for not having chicken for dinner, as she had intended. His answer was, "Good gracious! Aunt Cynthia, don't fret about that. It's a God-send, for, to be honest about it, we have had chicken for dinner and warmed up for breakfast every day at the last nine places in which we have thrashed, until it has got so that Lafe crows in his sleep."

The cleaning-up mentioned was done by running the thrashed chaff and grain through a fanning-mill to separate the chaff from the grain. This was done evenings, and all hands except such as were from a distance must go to the barn and run the fanning-mill until it was done, no matter whether it took until ten o'clock, until midnight, or until two in the morning.

The old sweep went out of fashion, and the next style of machine that came around was the tread horse-power, with cylinder and separator attached. The separator took the straw from the chaff, but did not separate the chaff from the grain. A little later came the self-cleaner, which was a great improvement, saving both time and grain, and rendered running the fanning-mill by hand unnecessary.

While on this subject I had, perhaps, better tell how thrashing was done in the early days before machines.

The flail was the primitive thrashing machine. It is a simple instrument -- merely a long stick with a knob on the end of it, to which is attached another shorter and larger straight stick 
by means of a coupling or cap made of wood and a rawhide thong, which allows a flexible movement in any direction.

The grain was spread upon the floor, a foot or so deep, and pounded with the flail back and forth - whack, whack, whackity-whack - until the flooring was gone over; then turned over and thrashed on the other side in the same manner, until the kernels were all pounded out of the straw. Two men sometimes worked opposite each other, striking their flails upon the same spot on the floor as they moved back and forth. This made elegant music-whackity, whackity, whack, whack, whackity-whack - and seemed to make the work go easier. The straw was then taken off and the grain thrown to one side to be cleaned up, which was done by means of a fanning-mill, if there was one; if not, by the more ancient implement, a grain fan or "corn fan." In the still more ancient times of Ornan the Jebusite, grain was winnowed by being thrown up and falling through the wind. The invention and use of the fanning-mill is said to have been strongly condemned by early Christians because it presumed to create wind, the prerogative of the Almighty. I have the original corn fan which father's people used in those early days. It is a great, wide willow basket, shaped like a broad scoop-shovel.

Thrashing with the flail meant an all-winter's job, and was wasteful of grain. When I was a very small boy, Paddy Martin, or some one else, was at work in our barn from fall to spring. The introduction of thrashing machines in England caused extensive labor riots, because of the wrong they were supposed to do to the man with the flail.

Grain was also thrashed with horses and colts by spreading down the floorings, putting the horses on the floor and driving them round and round on grain to be thrashed, first one way, 
then the other, then turning it over and driving them about again, until they trod out the grain. This was practiced to quite an extent, but was an unclean and wasteful method. Boys liked it, as it was fun for them to get in the center, like a clown in the ring, and hustle the colts. The colts also liked it, as they were worked under the old Mosaic law regarding muzzles, and had some fun biting and kicking each other as they went round and round.

\section{9}

\section{FALL WORK}

The fall work proper consisted of fall plowing, which was necessary to be done in order to insure good crops upon that soil; the picking up and clearing the fields of stone, which were hauled into great heaps or where they were to be used in building walls for fences. Digging out rocks and breaking them up was with father a kind of fad, and he had great skill and experience in the work. With no tools but common iron bars and long wooden levers which he made for himself, log-chains and a team of horses, he would take from the ground boulders that weighed tons, get them onto a stone-boat and haul them away where they were needed for fences. The uses of the stone-boat were numerous, but that of moving rocks and stone was paramount. The stones and rocks have now lost their value for fencing and are no longer hauled and carted around for that purpose. It took centuries for farmers to learn that cattle should be fenced in instead of out, and that one-fourth the fence would do it. I think there are many acres of land on that old farm upon which was spent labor enough, at a dollar a day, to have purchased fifty acres of much better land. 


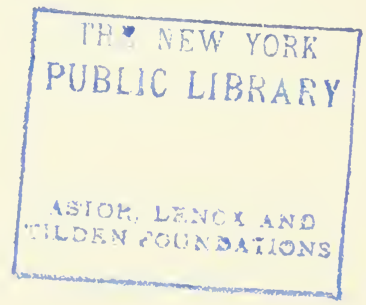




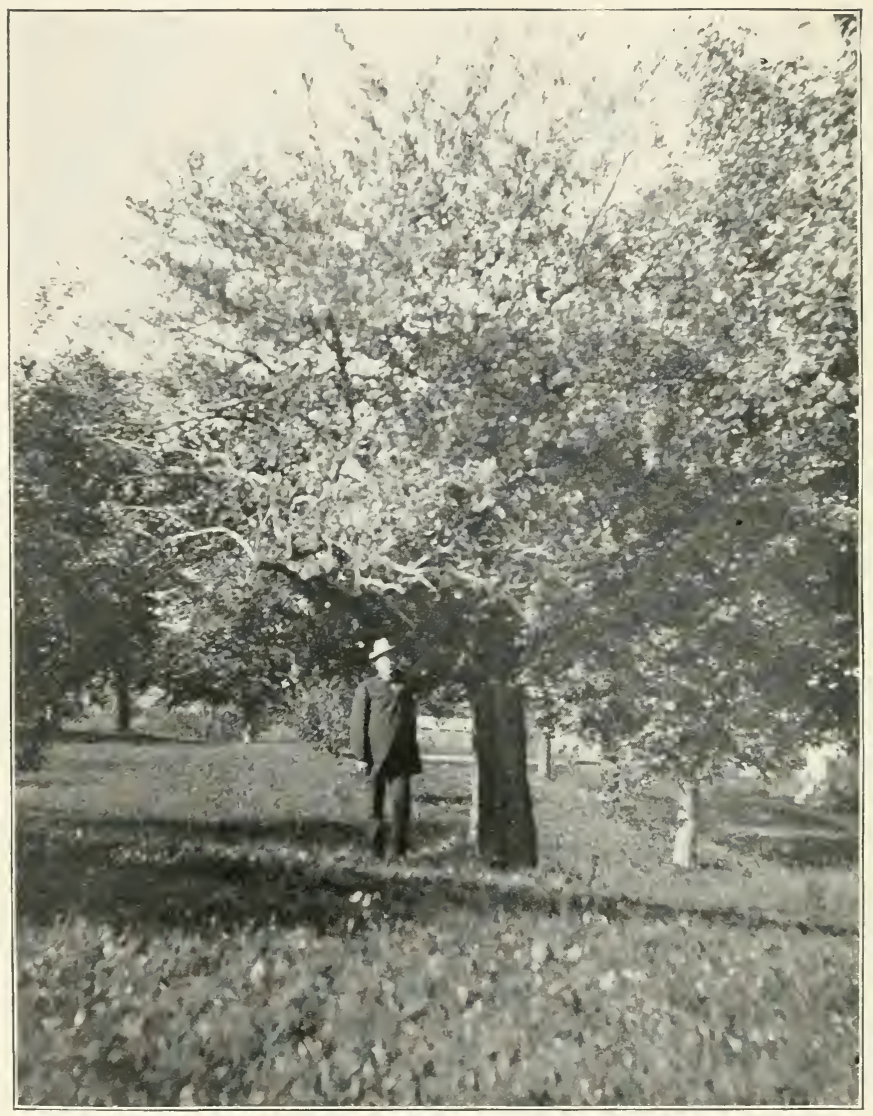

OLI) THISTLE TREE 
Before the frost came the corn had to be cut and set up in shocks, preparatory to drawing and husking. When cured the corn was usually drawn to the barn and husked evenings and rainy days. The potatoes must be dug before freezing or very muddy weather came on. Carrots, turnips, beets and such stuff were to be dug or pulled and put into the cellar or other place of storage. Sometimes the digging of the potatoes was unreasonably delayed until the cold weather came. This made bad work and cold fingers for the boys who had to pick them up. Once we took to the field an old foot-stove which was formerly used when traveling in the sleigh in very cold weather, or in church when there was insufficient or no fire. We would pick up potatoes awhile, then run and warm our fingers by the old stove, the original use of which was to warm the other extremities.

On the farm were two orchards of over an acre each - the "lower orchard" and the old or "upper orchard"- besides quite a few trees, both young and old, near the old house over the creek. The lower orchard was planted in 1823, the upper orchard several years earlier. Originally the trees in these orchards were nearly all what is known as seedlings, or natural fruit, some of which bore fruit of a quality and flavor excelled by no apples which I have since tasted. Particularly is this true of the old "Thistle Tree," which bore a small-sized yellow apple with black specks, of a rich, spicy flavor. It was a great and regular bearer, and there are hundreds of people alive to-day who remember the merits of "Old Thiss." It was named because of a bed of thistles which grew under it, and was the tree under which were found the most clubs.

The trees in both orchards all had names, like "Corner Tree," "Hard Sweet," “Winter Sweet," "Water Core," "Pear Tree," “Frost Tree," “Honey Sweet," “Upper Sweet," 
and "Old Pith" - these and dozens of other names, not forgetting "Old Grim," the fruit from which was so sour that the pigs when they bit into it dropped it and squealed. Every tree had a history, and every name a meaning.

The town of Lorraine had few good orchards; it was too high, cold and bleak. But father's orchards had a good start before the country was cleared up and enjoyed the protection of the forests until well grown. Apples were scarce in the locality, while we had a bountiful supply.

The gathering and housing of the apples was quite an event, and work which had to be done by the boys and girls or women of the place. We took no pains to pick them, but shook them off the trees onto the ground or into blankets and sheets, and stored them in the old cheese-house in great piles, there to remain until the hard freezing weather, when they were taken to the cellar. We did not take the pains to keep the kinds separate, except a few of the choice ones or such sweet apples as were required for making boiled-cider apple-sauce. Sometimes cold, snowy and frosty weather would catch us with part of the apples yet out. That meant gathering them under most uncomfortable circumstances in cold, windy and sometimes snowy weather. There were generally two or three hundred bushels of all kinds and qualities. From the small ones we made cider, sometimes using a small, home-made hand-mill, but more frequently drawing them to the cider-mill.

A quantity of cider from sweet apples was always boiled down for cooking purposes and for making boiled-cider apple-sauce. Of this we always made a large amount, which filled at least two big-bottomed store-tubs holding a barrel or more each. It was made from the sweet apples pared and carefully cut in quarters and cooked slowly in the boiled cider in a great, brass kettle in the 
big fire-place of the old kitchen. Paring, coring and quartering the apples was evening work, and many an evening was made to last until late bedtime before the job was done; but it paid, for it furnished a most delicious food that was freely used at all meals and between meals until the next June. The sauce was allowed to freeze up through the winter, which kept it fresh and sweet. I have never had anything in the lunch line which, to my taste, equaled cider apple-sauce and the long, white nutcakes, made tender, light and delicate, without sugar, which went with it.

To use the large amount of apples which were put into the cellar each fall, we were obliged to feed a great many of them to the calves and fowls. The geese were especially fond of hashed apple.

Later on, the lower orchard was grafted by a party of itinerant fakirs who set grafts by the hundred. They were turned loose in the orchard and grafted every limb they could reach or climb to. For a time it was a question whether they had not entirely ruined it, but it "survived the operation," and some of the grafts turned out pretty well.

I always think of these orchards and the bountiful supply of apples therefrom with very pleasant feelings, for it takes me back to the time when, with pockets all stuffed with the very best the cellar afforded, I could buy my way into the affections of the best girls in the school and bribe the ugliest boys to let me off easy.

Late in the fall came the butchering. To me this was an unpleasant experience. To see the animals we had cared for, waited on and associated with, brought out from their pens or stalls and cruelly murdered, was a sight I could hardly stand. The plunging of the bloody butcher-knife into the heart of a favorite pig, or the cutting of the throat of the clever calf, was 
something I never wished to see, and avoided it if possible. It was bloody, wet work, and the very worst and meanest job about the farm. I was very little help and never had anything to do with the killing, although I sometimes assisted after the poor thing was dead.

Hog butchering was winter work, which required changing work or hiring extra help. It was hard, heavy labor to scald and hang up big, fat hogs with the rude appliances which the average farmer had. When butchering day came, a fire was made in the arch under the big kettle long before daylight, so as to have the scalding-water hot. An old sled was brought up and put in position near the cooper-shop, which was not a great way northeast from the hog-pen. At its hind end a big potash or cauldron kettle was sunk into the ground and filled with hot water for the scalding, the sled making a table upon which the hogs could be dressed.

They were brought out of the pen, killed and scalded, and the bristles taken off with knives and old iron candlesticks for scrapers, disemboweled, washed out and hung up on poles which were stood up against the cooper-shop. The entrails were taken in large wooden bowls and gone over and "riddled" - that is, the fat was taken from the intestines and tried out by itself, as that kind of lard was inferior.

Sometimes the pork was sold by the carcass, but if not bringing a satisfactory price it was cut up, salted and packed in barrels, the hams and shoulders being smoked for home use or for sale.

Father always took great pride in having a good bunch of hogs each year and in making them into nice pork, and sometimes would have eight or ten to sell or pack that would weigh from three to five hundred pounds each. The meat brought a good price and was an important part of the income of the farm. 
His hog-house was not an old hovel or pen, but a first-class, clapboarded story-and-a-half building, with floors and rooms or apartments in which the pigs and old hogs could live decently and respectably, keep clean and enjoy themselves. They had two large rooms with a connecting door, which was closed as required, and a sleeping-room, which was always kept nice and dry, with clean straw or other bedding. In the summer they could walk out on a kind of piazza or veranda on the shady east side of the building, made with a good, substantial plank floor and a sort of lattice-work constructed of hardwood scantling. Here they could sleep, grunt and take their comfort between meals, with no thought of where the next meal was to come from and no care as to the fate which hung over them. There was a great difference in the hogs as to habits of cleanliness. Some were very neat and particular, others more careless. The sows were generally much the cleanest and neatest in their habits. As with human beings, it seemed to run in the breed or families. The downright dirty pig was not long tolerated. His habits were offensive and his example pernicious.

The packing and care of meat, both pork and beef, was very important, for if it was carelessly or ignorantly done the meat would spoil in the barrels, and hams which were improperly cured and smoked were of very little account, and sometimes an entire loss. Our smoke-house was the old, big fire-place in the cooper-shop, the front part of which was closed up, and sticks put across about four feet from the ground, upon which to hang the hams. The smudge or fire from cobs or green maple chips was kept up under them until they were properly smoked. Before smoking they were first cured in a pickle of brine and saltpeter and well rubbed with sugar. If allowed to remain in the pickle too long, they were salt and hard; if not long enough, 
they were improperly pickled through and would spoil as soon as hot weather came.

It was a custom in our neighborhood when a family " butchered" or killed a fat steer, sheep or lamb, to send a good, liberal piece to the nearest neighbors who at that time were known not to have a supply of fresh meat. There were no meat-shops, and this neighborly courtesy was highly appreciated. Ice-houses were uncommon, and in hot weather very little fresh meat was had or used. In the cool weather of the spring, fall and winter, there was always plenty of it, and in the summer-time occasionally a lamb was killed, dressed and hung down in the cold well to cool and keep - not in the water, but suspended above it. There was never any scarcity of food; always plenty and of the best quality.

\section{3}

\section{TROUBLE}

My earliest memory of anything about home is of being tossed up by my father when he came in from work, and of being down and around the school-house which was on the corner near our house.

Sister Sophronia always claimed that I was sent to school before I was weaned, and was obliged to go home at recess for my lunch. That may have been her joke, or it may have been and probably was - something pretty nearly true, as I was the only "baby on the block" available for the use and amusement of the school-girls.

The days of babyhood on the farm were few and soon past. The period of helpless, do-nothing existence was cut short at 
the very earliest time possible. As soon as we could walk and talk plainly, something was found for us to do. Chores and errands of all kinds kept us trotting about, so that we thought we were doing a lot of work. Whether it helped or not, it at least kept us out of mischief, and early taught habits of industry; but the work done and required of a boy from seven to ten years old in those days, and particularly on father's farm, could not be said to be of little account.

When very small he could pick up chips, of which there were a plenty about the great woodpile in the dooryard, and as he grew up he was put to any and all kinds of work and use which his strength and intelligence would warrant. He could bring home the cows and drive them to pasture, could salt the sheep, watch the crows to keep them from pulling the corn, hold the horses, carry water to the field, ride horses to plow corn and potatoes, pick up potatoes and apples, tend fires, call the men to meals, run errands about the farm and neighborhood, hold lights for those who were obliged to work evenings or nights, bring in wood, or feed cattle. The errand business with me was a strong leader. I was used as a sort of wireless telephone, both long and short distance, and was a combined telegraph messenger and express service. There was no end of errands to be done on and about the place, and as soon as large enough I had a monopoly in that line.

My elder brother John and three sisters were at home when I was of this age of all-round utility. They all had their chums and acquaintances with whom it was desirable to communicate frequently. There was but one span of horses, or a pair and one extra, and they were generally busy. Telephones and bicycles were not yet invented, and my nimble heels seemed to be the only quick communication and rapid transit available. 
Being the youngest in the family, I was expected to take orders from the seniors. If father said, "Boys, bring me the crowbar from the sawmill" - and he usually did give such order without specifying by name-John always turned to me with, "Hen., you put," and I did. To back up meant trouble. Father always sustained him in his transmission of orders, and besides that, he could lick me until I was fourteen or fifteen years of age - in fact, he did give me more trouncings than my father ever did; but I could argue the point and talk back to him, which I could not with father. If one of my sisters called me to "clipper" over to the "Huddle," two miles away, with a note, package or letter, and I demurred on account of bad roads, the weather, or any other to me apparently good cause, an appeal to mother always resulted in her orders being approved, usually in these words, "Henry, you mind Mary," and that settled it.

I am not saying that I was abused or injured by this kind of discipline, neither was this service all upon compulsion; indeed, I got my share of fun out of it. I kept both eyes and ears open and generally knew what I was doing and what it meant, and frequently became well posted on matters of public and personal gossip, which gave me unusual interest in affairs and considerable importance for a small boy. I tried to be trustworthy in my capacity of either general or confidential messenger, and with this reputation fairly established, I had what at times was an enviable and almost disagreeable monopoly of the business, both at home and with the school-ma'ams and big girls who attended the district school.

I remember how one of my teachers took me into her confidence as to her beau, to whom she wrote about every other day all summer. No one else was allowed to stay after school and 
see her pen the sweet epistle, or permitted to take the same to the post-office. Of course, no one but herself and myself ever knew his name.

And this reminds me of a serious mishap and financial embarrassment I had on her account. One evening when I reached the office with her letter, I found I had lost the little silver sixpence given me to prepay the postage. I was in great distress. The letter must go by the next mail. She had told me that he would expect it Sunday. I felt both grieved and guilty and did not know what to do, but hung about the office and store for nearly an hour, hoping to see somebody I knew, or that something would turn up to help me out of my trouble.

The postmaster, Elihu Gillett, saw my embarrassment and asked me what was the matter. I told him of my loss and showed him the letter which I wished to mail. He said, "No matter, boy; I will send it 'collect.', That meant twelve cents to pay at the other end. I realized this would never do, and told him I did not want it to go that way. He asked whose letter it was, and I told him that I did not wish to tell. Then he asked my name and whose boy I was, and having looked very serious for a minute, which to me was a most anxious one, he said, "You look like an honest boy. Will you pay me if I mark the letter prepaid?" I promised most faithfully and gladly that I would.

I worried over it going home, and could see no way to get out of it without confessing the loss and my carelessness to the school-ma'am; then, perhaps, I would lose her confidence and some other boy would become her favorite - a thing I could not bear to contemplate. I had no sixpence to make good the loss, and the next morning confided the trouble to my mother, who helped me out of the difficulty without getting the name of 
the school-ma'am's beau, although she did ask. Two days thereafter I carried another letter to the postmaster for the teacher's beau, paid the money he had so kindly advanced me, and received from him the assurance that I was an honest boy, just as he thought.

The dear teacher, long since dead, never knew the hours of trouble and anxiety the loss of the sixpence which was to pay the postage on her love-letter had cost me. I have handled millions of trust funds since, and have suffered personal losses which worried me, but never have experienced the same deep sense of financial responsibility, trouble and anxiety which I had over that, my first financial embarrassment.

After the summer and fall work was closed, the children had to be made ready for school, which usually commenced in December. This implied repairing their old clothes and making some new ones.

A shoemaker was engaged who went around the neighborhood with his bench, which had in one end of it a wheel and in the other handles, so that it became a wheelbarrow which could be trundled from one house to another, carrying his tools and such material as he furnished. This was called "whipping the cat." He came to the house and stayed a week or more. He measured everybody's feet, and made all the shoes and boots needed. $\mathrm{He}$ worked early and late, which required the holding of a candle for him - another disagreeable job for the small boy. The leather which he used was from the hides of animals slaughtered on the farm and tanned at the halves in John Bentley's tannery. There was always a good stock of soleleather, cowhide, kip and calfskin on hand with which to make anything for which leather was required.

The shoemaker whom I best remember was Paddy Carter. 
The work he did was creditable, and this method of having it done saved a large item of expense. Father also had a shoebench and tools, and, while not an expert, could make first-rate, serviceable boots and shoes, and when times were particularly hard, did make them for the family. He almost always did all the tapping and mending. This saved a great deal of time as well as money, as the nearest shoemaker's shop was two, and in early times six miles away.

Country boys, although used to going barefoot, enjoyed boots made of "good leather" that would turn water and not soak up soft and white. There were no rubbers or gum-boots, and their own comfort as well as pride made them careful of their winter boots, which were dried every night and greased every morning. Fine boots with red tops were a luxury and the pride of the young countryman. I never was able to secure a pair until I was sixteen or seventeen years old and big enough to have my say about what I would and would not have.

Clothes were made at home by a tailoress who came to the house and measured, cut and sewed for two or three weeks. In this she was helped by all the women of the house, who while helping her stole her trade, watching carefully to see that they understood every point in the business. The clothes were cut by making patterns from old ones, by rude measurements, by trying and fitting, ripping out and cutting over, until they succeeded in getting something that would pass muster. I have heard it said that in very early times they used to get at a boy's size and shape for a pair of pants or a jacket by laying him down on his back on the floor and marking around him with a piece of chalk.

The cloth from which the so-called home-made clothes were manufactured was mostly made in the weaving-room of the 
house, and our clothes were good, durable and warm, if not particularly handsome. Dresses and other garments were also made for the girls from the same material or something lighter. A favorite brand of cloth with mother was what she called "hard times," from which was made all kinds of every-day clothing. It was coarse and stout, and would last longer between a boy and the snow-crust than any other fabric used. Overcoats were not thought necessary for boys until they were well grown, and my first dress overcoat, costing six dollars, of which I was very proud, came from a ready-made stock. "Store clothes" gave a boy airs, but the creases had to be ironed out of the pants before he would be seen in them.

\section{3}

\section{THE DISTRICT SCHOOL}

So much has been written and said upon the district school as an educator and its results in making the character of the American people, that I need say little upon that head. I shall simply give my memories of the methods used and events happening in the old home school from 1843 to 1859 . The plan then followed was a good one, and, in my opinion, much superior to the common-school educational system now in force.

The system I refer to was that of the old town superintendent, operated under the rate-bill rule, or, later, what was known as the state-aid or free-school system. The town superintendent was always one of the best educated and most practical teachers in the town. He examined and licensed teachers, visited the schools two or three times each term, and, by personal 
inspection, advice and suggestion, was able to control and direct the work and the methods so as to produce the best possible results. The teachers had been thoroughly educated in the same class of schools in which they were to teach. They usually boarded around, and knew the necessities, habits and customs of both parents and scholars, and understood and appreciated the conditions and surroundings of each. They realized the value of school time to the average student of little means, and did not keep him drilling on useless subjects. Knowing that the most of their pupils could only have a common-school education, and that a short one, they made it a common-sense, practical one, teaching only those things that would be of most use in the general business of the world. The work they turned out was better, and the men and women they helped to a thorough, practical, English education were much more numerous in proportion to the attendance than to-day.

The schools were usually large, the winter schools especially, filling the school-house to its utmost capacity. My earliest recollections of school and school-days are a little vague, for the reason that I was sent, or rather taken, to school at a very early age, but I can now remember standing up by the knee of some lady teacher while she taught me my a, b, c. The fact that our people lived within a few rods of the school-house, and that I had sisters among what were known as the big girls in school, was doubtless the reason of my being sent or allowed to go to school so early.

My first clear recollection is of the winter school kept by Henry Hull. His regime as a teacher is vividly remembered by every pupil of that school yet living. He was an energetic, tireless man of about twenty-five or thirty, was severe in discipline, and used the blue-beech and ruler without mercy, and, as now 
seems, with very little sense. He built his own fires, swept his own school-house, opened early and held late, and taught in his shirt-sleeves, with a book in hand, as he walked up and down the floor, Argus-eyed and vigilant. He wrestled with the boys, or played games with the girls in the school-house, noons and at evening. They all liked him and were diligent in their studies. He was the model teacher of the town, and the town superintendent in his visits took pains to commend his work and that of his pupils.

The school was a large one. I think he had nearly fifty pupils, all that the school-house could possibly seat, with a few old splint-bottomed chairs, contributed by the neighbors, for some of those who could not sit on the benches. The schoolhouse was rude and rough; the desks, made of two-inch plank, put up a little slanting, run clear around the house. Long benches made of basswood plank, which was the softest lumber to be had, were used for seats. They had no backs, and the student turned around on his seat by swinging his legs over the bench to face in or out, as suited his fancy. Generally they sat close, and when one wished to turn around his neighbor had to get up. Then there were two long, low benches, made of the same material, which had backs. On these the little children were placed who were too small to require desk-room.

The punishment meted out to malefactors among the big and little boys was sometimes severe. Boys did meaner things than girls, and that with malice aforethought, to annoy the teacher. It was thought to be a proper thing to get off almost any kind of a practical joke on the teacher or on one another; if it could be done and not get caught, all right, but if detected, there was trouble. Then came investigation of the case and judgment, and sentence and punishment were never delayed. 
I remember seeing Hull punish a large boy, James Patterson, about twenty-two or twenty-three years of age, who was six feet tall and big enough to eat him up if he wanted to. Patterson had maltreated a little octoroon boy who belonged to the school. Patterson did not belong in our district, but was there by permission of the teacher and trustees, as the school was considered an extra one, and he was anxious to get the benefit thereof. $\mathrm{He}$ was given the privilege of taking a flogging or leaving the school. He chose the whipping. Hull, suspicious that he might back up and use his giant strength when it came to the execution of the sentence, called in William Johnson, who was running the sawmill, a few rods away. Then he took down one of the bluebeech whips which hung over the blackboard, opened the stovedoor to warm it and make it a little tougher, told Patterson to come on the floor in the middle of the school-house and take off his coat, which he did, while Mr. Hull gave him a thrashing which was cruel enough to break the heart of an ox. Patterson shut his teeth, grew red and then pale, but held his temper and went to his seat, a wiser and better man. I do not allude to this whipping business as entitled to approval. It was cruel and almost uncalled for, but in those days it was considered the proper thing. The whole population of the district were of New England Puritan stock, and believed in the Bible and its assertion that " to spare the rod spoiled the child." No other teacher that I remember inflicted corporal punishment to any such degree.

The school was not a graded school in the sense of to-day, and yet it was graded so far as possible and practicable. Classes were formed in all studies according to the advancement and capacity of the pupils. Bright scholars were not held back because of the incapacity of dull ones, and in that respect I can see where the old system far surpassed the present. 
I will not stop to follow the different grades through which I went. The classes were something like this: English reader class, which only admitted the best readers and elocutionists; first reader, second reader and third reader; the spelling-book with its $a-b, a b s$, and short sentences for the little ones. Then there were first, second and third classes in geography, spelling, arithmetic and grammar. The ambition and rivalry to get from a lower to a higher class was active. Each pupil who was large enough had his writing-book in which the teacher set copies.

The terms were short - about thirteen weeks, I think — and most of the scholars, in the winter schools at least, realized the importance of thorough application. Spelling and evening grammar schools were common, and both branches were taught in that district more thoroughly and satisfactorily than I have ever seen in any other school of whatever name or degree.

Mr. William Barton lived in the district and was for a long time the town superintendent; he also taught the school several winters. His health was not good and he was not a strong man, but as a country school-teacher there were few like him. Where he got it no one knew, as his education was only that of the common school and the old academy, but he was one of the best grammarians and teachers of grammar, spelling, elocution and rhetoric in the county of Jefferson. It seemed to come natural to him, although country born and bred. He was also a first-class teacher of arithmetic, geography, astronomy, natural philosophy and algebra. As a teacher he was the very reverse of Henry Hull, and the only criticism made upon him was that "he did not have good government." He seldom, if ever, whipped, and when he did, hurt no one - a kind, good-hearted gentleman, who always did right and expected others to do the same. Under his tutelage those scholars who desired to 
advance and improve themselves did so rapidly, and his teaching was the base and foundation of the education of scores of excellent teachers who later graduated from that district school.

Another teacher of marked ability and striking eccentricities was Mills Wilcox, oldest son of Elder Wilcox. He taught the school the very last term that I remember to have attended. He had received an academic and, I believe, a college education, had been West and had the fever and ague, but for some reason was home and took the school for the winter. He was entirely different from the two other teachers described, but had an advanced lot of scholars who were very anxious to take advantage of his ability and extensive knowledge. He also had no government. None was required, for if the little boys made too much noise, some of the older scholars checked them. There were no rules against whispering, or leaving your seat, or going out, or doing anything else in or about the school-house. He assumed that such things only would be done as were right and actually necessary, and he was not disappointed in his assumption.

He taught all the common English branches and, in addition, algebra, geometry, astronomy and Latin. He was a superior teacher in reading and elocution. His health was poor, and occasionally the shakes would get him, and he would leave the school-house and go to father's house, where my mother would give him a big dose of ginger tea and put him to bed for an hour or two. He would then come back all right, except a little pale. While he was gone the school was turned over to some of the big girls or boys to run, and no advantage was taken of his absence.

He was never very particular about a few minutes before nine or after four. All there was of it, the work had to be done and 
was done. I remember that he had an old "bull's-eye" silver watch which sometimes ran, sometimes not. The boys soon learned that his watch was somewhat lame and antiquated, and about half-past three o'clock would ask Mills, "Mr. Wilcox, if you please, what time is it?" Mills would pull out the old "bull's-eye" with his left hand, look at the face, glance through the southwest window towards the sun, and answer, "Three o'clock and thirty-seven minutes;" then, if he forgot himself, would walk towards the blackboard, shake the watch and put it up to his ear to ascertain if it was ticking.

But I cannot spend all my time with the winter schools or the men teachers. The memories which are the clearest and sweetest to me are those of the dear "school-ma'ams" of the summer terms; indeed, they sometimes taught in the winter also. The one who taught me the most terms was Lucinda Barton, always called "Aunt Lucinda," not so much on account of her age, although she was an old maid, but because the Barton children, of whom there were several in school, always spoke to her as Aunt Lucinda, and the rest of us took it up and respectfully used the same kind appellation.

Like her brother William, she was an excellent, conscientious teacher, and besides was a good woman, who would not hurt a fly if she could help it. She had to deal with the roguish pupils of the summer school, which was composed of the small boys and girls who were big enough to go to school and yet not so large but that they could be spared from the farm and house work. They were like the average boy and girl from five to twelve years of age, and it is well known that a boy about this age is the most mischievous and meanest in his whole life and the boys of District No. 4 were no exception.

Aunt Lucinda was indefatigable in the school-room, giving us 
most thorough instruction and unlimited practice in all that small children were then taught. She taught us the multiplication table, which she made us sing to the tune of "Yankee Doodle," to impress it upon our memories; counties in the state and towns in the county; states in the Union; capitals of states and foreign countries; the tables in denominate numbers, such as apothecary, troy and avoirdupois weights, dry and wet measures; spelling and the definitions of all the words in the spelling-book, and anything and everything that well-educated men and women ought to know, and which scholars educated under the present system do not seem to know. She taught us how to sing, and every morning, noon and night she had some pretty piece of song or ballad in which she led, while we piped it up to "beat the band." This bit of one of her favorites I still remember:

" $U_{p}$ the hill on a bright, sunny morn,

Voices clear as a bugle-horn,

List to the echoes as they flow-

Here we go, we go, we go."

She read the scriptures and prayed to and for us every morning at the opening of the school. There were no Romanists in our school district, and her kind, religious teaching and motherly advice was appreciated and approved by our parents, if not by ourselves. In return for this kindness we gave her about all the trouble that we could. If she made rules we took great pleasure in evading or breaking them, although we had to go out of our way and make an extra effort to do so. Then she would keep us after school and talk to us, when we would be penitent and make the best of promises and assure her of our most profound respect and love, which always settled it with Aunt Lucinda.

We enjoyed ourselves hugely at recess and noon, and before 
and after school, in all our childish plays. A favorite with us, both girls and boys, was what we called "playhouses," which we built along the sloping and high bank of the sparkling, clear creek, in the shade of the beech and birch trees which overhung the same. Sometimes they were quite elaborate, fitted up in good style, with make-believe dishes, rude seats and furniture, such as we could put up ourselves.

The material for the playhouses was always convenient from the slab piles and waste boards around the mill, which was within four or five rods of the school-house. Sometimes we united with the girls and made a genuine keep-house playhouse, the builders modestly hinting who was who and what was what, as to the heads of the family in the house or houses, but more frequently there prevailed a mild condition of war between the larger girls and us larger boys - by larger boys I mean such of us as were from eight to twelve years of age.

One day at the boys' recess, Leander Fox, Buck Wilcox, myself and a Cramer boy destroyed one of these girls' playhouses which was under the big birch tree, a little way from the school-house. We razed it to the very ground and hurled the boards of which it was constructed, and the dishes, furniture and household gods which it contained, down the bank into the rippling waters of Deer Creek. When the girls went out they learned of the outrage, and immediately came in and complained to Aunt Lucinda that the boys had torn down and destroyed their pretty house. Of course, this required an investigation, and, after calmly thinking it over, Aunt Lucinda began the same.

We realized that we had done a sneaking, mean thing, but had conspired together, talked it all over and agreed upon our line of defense - namely, an absolute denial as to the real per- 
petrators of the crime, and an agreement to swear it onto Quincy Griffin, a harmless, good-natured octoroon boy of about our own age, who had nothing whatever to do with the outrage except as an innocent witness.

Aunt Lucinda began the questioning, and we each and every one, as she solemnly asked, "Who tore down the girls" playhouse?" told her that it was Quincy Griffin. Quincy was dumfounded and did not even retort in his own defense, as we expected, by telling who it was, but stood up and took quite a good feruling from Aunt Lucinda - that is, quite severe for her - while he looked at us in amazement, the tears trickling down his cheeks, whether because of the smart of his hand or the sorrow which he felt for our contemptible degradation, we did not know; but for his discreet course and manly action we praised Quincy and were good to him for quite a while. What would prompt decent boys to do so mean a thing and tell such an outrageous lie about it, cannot be accounted for on any other theory except the old reliable orthodox one of total depravity.

\footnotetext{
" Why the boys should drive away

Little maidens from their play,

Or love to banter and fight so well,

That's the thing I never could tell."
}

Leander was an extra good boy, but he used to get into scrapes and disgrace as often as the rest of us. Once, I remember, he had done something for which Aunt Lucinda said he must stay in the school-house at noon. It was his custom to go to his home, which was but a little way, for his dinner. He told her that he could not stay, that his mother would expect him to dinner. She told him that he must stay, but fearing that he would not, she unwound from her leg a long, red, white and 
black knit garter, with which she tied Leander to the little bench. After she was gone he dragged the bench outdoors and sat on it in front of the building. The garter was not drawn so closely that he could not untie it, but he was told if he did she would have to punish him more severely. What that could have been is hard to guess, as Aunt Lucinda never planned cruelties. As it was, the punishment Leander got was considerable and the mortification thereof stayed by him long. We promoted him and called him a " Knight of the Garter."

One of the teachers of very marked ability and strong per. sonality was Diantha Gillman. She lived in the district and taught the school several terms. She was small but muscular, and had the energy of a steam engine in her little body. No winter storm could keep her from reaching the school-house, although the drifts might be over her long-legged calf boots which she wore when very stormy. She was a favorite with the neighborhood as well as the school, and enjoyed the respect and love of every one who knew her; but the average small boy, although loving and respecting his teacher, must necessarily show off and be mean, that other boys and girls may know how smart he is. And right there is where I made a big mistake one day.

We were saying the counties, and I was at the foot of the class - not that I was always there, but because I had been at the head the night before. It was a long class, and they had been droning over the names from the head to the foot, and I had got tired and shifted from one foot to the other. I wriggled and looked out of the window and was as uneasy as a fish out of water. When it came my turn I put on a little steam and rattled along through "Albany, Allegany, Broome," and so on down the list, ending up with "Westchester, Wyoming, Yates," 
and when I struck "Yates," almost yelled it out. Diantha's eyes snapped as she gave me a withering look and coolly said, "Henry, you can go through the list again." This I did, faster than before, ending up, “Westchester, Wyoming, Yates," dropping my voice to a low growl. By this time her eyes looked more and more dangerous, and she quietly said, "Henry, you may go through the list once more."

It began to get serious. The whole class were intently watching. It was a question whether a young man like me was to be cowed down by a little woman, or whether I was to maintain the independent and fearless position and manner which I had assumed. I did not go through the list quite so fast the third time, because I was revolving in my mind what would probably happen, but as I came down to "Westchester, Wyoming, Yates," pronounced "Yates" with a kind of hissing whisper. She did not stop to argue with me as to the impropriety or impudence of my conduct, but asked me to come out on the floor behind the old cast-iron stove, the class still standing. I really did not know what to expect, or I think I should have gone through the school-house door. Diantha had never struck me - at least, not to hurt me so that I remembered it - and we were then, as we always have been since, the very best of friends.

I walked out on the floor believing and fully calculating that, whatever came, I was going to show off before the class that I was a man. She took out of the desk a short, blue-beech branch which had been cut from the sprangly tree which grew on the bank in the rear of the school-house. I was dressed, not for the occasion, but more properly for the season. I remember just what I had on - a tow shirt and a pair of tow pants, with a pair of suspenders knit of wool yarn. Without saying a word, 
she ran her long, slim fingers down inside the back of my shirt and gripped the collar as with hooks of steel. As I before said, she was a very muscular young woman, and had uncommon strength in her hands and wrists, which had been developed by milking twelve cows night and morning in a large dairy, in addition to her duties as a school-teacher.

Her arm stiffened, and as she held me at arm's length she began to lay on the whip. Every blow stung like the cut of a knife, but they came fast and faster. It was more than I was looking for and more than my pride could stand. My manhood gave way, and I commenced to blubber and dance around Diantha like a young Comanche Indian in a sun-dance, but I could not get away. I could go round and round, but her grip on my collar kept me at just the right distance so she could play the whip to good advantage. Of course, at this remote day I dare not undertake to say how long this lasted. At the time I thought it was by far too long. The sun was shining through the west windows of the school-house across the room, and in its gleams could be seen the air filled with dust and fine tow which she had swingled out of my shirt and pants.

My standing with that class as a bold, brave man was down and gone forever, and I took my seat keenly sensible of my degradation in the eyes of those whose admiration I had expected to secure. I have never forgotten the list of counties, and shall never forget the face of the dear teacher who so thoroughly impressed them upon my memory, while at the same time she taught me that it was not a good thing to be too smart. She is yet living and in good health, but whenever I call upon her, which I try to do as often as I can, she pretends to have a great failure of memory with regard to the details of the affair related.

I always tried to stand well with my teachers, and it is one 
of the pleasing things now to remember how the boys used to compete for the favor of the school-ma'am. To be the schoolma'am's pet was my ambition, as well as the ambition of many other boys in the school. We carried her flowers, apples, cherries and fruit of all kinds as it came along - anything and everything that we could get hold of that we thought she would enjoy - and we were more than pleased if the gift was accepted graciously. Every little bit of news which we got hold of first was communicated confidentially to her, even at the risk of being called "tattle-tale."

There was no well at the school-house, and the water had to be brought from my father's well. It was considered a pleasure to go for a big pail of water up to Deacon Lyman's well, wind the same up from its cool depths on the old windlass, and after having brought it back to the school-house, to be honored for the service by being appointed water-passer. To do this we used a big tin cup in which it was dipped from the pail, and in a most polite manner first passed to the school-ma'am, then around the whole school-house to every one who was thirsty, and it seemed that every one was always thirsty, and the cup had to go back and forth a dozen times before all were served. That was before the days of microbes.

Once Emory Barton had a long crying-spell because he, having gone for the water, was denied the coveted pleasure of passing the same to the school-ma'am and to the scholars; and all through life, whenever I have seen a grown person fretting over some fancied slight or neglect, or failure to recognize his merits or ambitions, I have said to myself, "He wants to pass the water to the school-ma'am."

The play about this old school-house was modified and largely determined by the surroundings. There was a nice creek under 
the bank just back of the school-house, a sawmill with great piles of logs and lumber surrounding the premises, a big ditch with a mill-pond just a little way above, a steep hill just across the creek, and other features of the topography which suggested and made practicable the plays we adopted, which were according to the age of those engaged - building little raceways, dams and mills, tetering over logs, "hi-spy" (or "I spy"), swimming, skating and sliding down hill, wrestling and black-man, with the usual "one old cat" and "two old cat," for which we used a soft ball wound from old stocking ravelings and covered with leather.

When it was necessary that the school-house should be cleaned, it was done by making a bee and asking the large scholars to come and bring soap, sand, mops and brooms, and heat water and give it a good, thorough cleaning. There was no janitor. The teacher did his or her own sweeping, and the men teachers built their own fires in the winter, or, if they chose, they hired some boy to do it for them. My avarice got the better of me for two or three winters, and I did this work, building fires and sweeping out the school-house for the teacher. It was before the days of labor unions, and I did it for what I had a mind to, or what the teacher had a mind to give me, which was one cent for each morning, and I furnished my own kindlingwood at that. At the end of the first winter I had coming to me seventy-one cents. It set me up quite a little. I was in funds as I never had been before. I really did not know how best to invest my money, so mother took it for me and put it in an old pewter teapot on the top shelf in the pantry. The per diem was not all that I made out of it, for I had carefully saved the ashes, and in the spring sold five bushels to an "ash-cat" for twelve and one-half cents per bushel. 
Spelling schools were quite a feature of the winter schools. Scholars came from the other districts to compete and spell us down, if they could. They seldom did - and never, that I remember, when Nancy Gillman and Henry Wilcox were with us. Then there would be a sort of return match in another district, and we contested with them on their own ground.

There were evening grammar schools, in which parsing from the English reader and Pollock's "Course of Time" sharpened the wits and broadened the understanding.

Saturday afternoons came "speaking pieces," and composition and miscellaneous exercises, which varied the monotony. We had good talent in this line. There were the Wilcox boysHenry, Whitfield, William and Lumund - and the BartonsAlvin and Enos - all able declaimers, and they often made the old school-house resound with "The Turk was dreaming in his guarded tent," "On Linden when the sun was low," Thanatopsis, Mark Antony, and other famous extracts.

School exhibitions were common, and the close of school was celebrated by an elaborate one, for which we carefully prepared.

Once we had what was called a "town exhibition," under the patronage and management of the town superintendent. It was held at the "Huddle" in the old Baptist church. We were drilled for several weeks on speaking pieces, dialogues, compositions - anything and everything to show us off to the best advantage. When the day came we formed at the school-house and marched to the place of rendezvous, about two miles, through the dirt and dust. We were all in our smartest Sunday clothes. My shoes had in some way become unwearable, and I did not know it until the morning of the celebration, as I was going barefooted that summer. The dilemma was met by my 
sister Sophronia, who was never discouraged or overcome by any ordinary embarrassment or obstacle. She hunted out and put me into a pair of her old morocco shoes. They did not fit very well, and were about two inches too long. Of course, before I had gone half-way to the "Huddle" in the procession, in which I had the honor to march under our beloved teacher, Louise Bentley, the boys were guying me unmercifully. I did the best I could to brace up and show my indifference; but their jests took hold, and when I went to the platform which had been erected in front of the pulpit, with some others of the class, and was told by one of the boys who stood next to me, loud enough for the others to hear, that I must not try to toe the mark, because if I did I would be way behind all the rest, it broke me down completely, so that my part in a startling dialogue was a disastrous failure. But the dinner in the neighboring grove, provided by the good ladies, with the big sugar loaf-cakes and a barrel of lemonade, cheered me up so that I went home feeling all right, carrying Sophronia's morocco shoes in my hand after leaving the State Road.

School meetings were a very important occurrence in the district. At the appointed time the voters of the district met and wrangled over who should get the wood, or whether fifty cents or seventy-five cents should be expended in putting in new glass, or whether they should have a man or woman teacher for the winter. They were occasions of great importance to the orators of the district, who discussed these seemingly unimportant questions with as much dignity and earnestness as senators. Some very hot discussions were had, and at times, when the more important questions of dividing the district or removing the schoolhouse were raised, considerable feeling was exhibited.

There was usually some young fellow in the district who was 
a leader of other boys in their plays, and particularly in getting them into mischief. With us this office was held by Monroe Fox. He was always jolly and good-natured. It was easy enough for him to see how to get the other boys into a scrape and keep out himself, which he generally did.

One day the Fox boys - Leander, Leroy and Monroe-with John and myself, were sitting on the bank of the road by the lower orchard in a sort of committee of the whole, discussing various questions, particularly those of heroism and notorious exploits in which we had been or felt competent to engage. Just then William Barton came along from the direction of Mr. Fox's house. He had an old sorrel, white-faced horse hitched to the old family buggy with a high back, a very ancient institution. In the back of the buggy lay a branch of blueberries which he had picked from a bush that grew near the little gulf.

What put it into his head God only knows, but Monroe called to me, "Henry, I bet that you dasn't grab that bush of blueberries out of Mr. Barton's buggy when he comes along." I denied the insinuation, and told him I would show him what I dared do. Mr. Barton came along on a slow jog trot, and when just fairly opposite us I made a dart from the side of the road and grabbed the bush from his buggy. It was a fatal mistake, however brave the deed. The next thing I heard was the hiss of the old woodchuck whiplash as it cut the air and wound around my face. It was about five and one-half feet long, of woodchuck skin, home-made, braided with a big belly in the middle, and attached to a hickory whip-stock about four feet long and strong enough to send it with any force which the man at the butt was capable of exerting. It took me a little by surprise, and when he gave it a jerk to unwind it and untangle me, he stopped his horse, and, turning to me, slowly, coolly and 
calmly remarked, "There, Henry, you-just-learn-not-tomeddle-with-things." I learned it, but at the cost of being joked and ridiculed by the boys all summer.

Music was not taught in the day schools of those times, but among the winter's entertainments the singing school took the lead. A teacher was employed by the term of so many nights. He was paid by the contributions of those who desired to keep up the standard of vocal music in the community. Neighbors accommodated one another with rides to and from the singing school as best their means of transportation would permit. While there was a large amount of fun and frolic for the young people in these gatherings, they were commended and sustained by all the townspeople, as their work contributed to the pleasure of all and was of especial importance to the churches. A grand concert was given at the close of the term, for which they had much rehearsing and practice. This was always accompanied by the usual squabbles of singers about who should sing the solos and duets. Not being a singer or capable of making one, my share in these affairs was small, and generally consisted in hitching up and putting out the team, but sometimes I went along with the rest and trusted luck to turn up some kind of amusement for which I had taste and capacity.

In the summer there were Sunday afternoon singing schools, held simply for practice and enjoyment of the singers - a kind of praise service, which greatly promoted friendship and matrimony. They met about four or five in the afternoon and wound up by pairing off and each couple going their own way for their regular Sunday night "sparking." 


\section{AMUSEMENTS}

"Where the pools are bright and deep,

Where the red trout lies asleep,

Up the creek and over the lea,

That's the way for Billy and me."

Such amusements and sports as we got had to be snatched or stolen. We always had excellent trout fishing close by, and used to get our share of it.

Deer Creek ran through the farm and was well stocked with a superior grade of speckled trout from its source to its mouth I mean the broad, red-bellied fellows. If we were good boys and had finished the most pressing of the work, we could go fishing the first rainy day. Of course, if we got away in a rainy morning we did not get back until we wanted to, even if the sun came out and the day cleared up.

Brother John was the best fisherman of the family. Father was too busy and had no disposition to "fool away time," as he regarded fishing and hunting. Our tackle was a home-made, shaved ash rod or natural pole cut from the woods. We made our own lines, either black or white, by twisting the hair from horses' tails by means of quills. Old Dick furnished the white lines, old Tom the black ones.

Hooks cost money and were a scarce article, and the loss of one was the cause of much regret. If a hook got fast we waded in to release it, no matter how deep or cold the water. The hooks were tied or wound on with silk or strong black thread. There were no snoods, leaders or flies; no reels, fish-baskets or landing-nets. The bait used was the angleworm, which, by the way, has never been excelled for catching brook trout.

We never "played" or fooled with them when they bit, but yanked them out with a vicious jerk-"twitching," we called 
it - that would send them sky-high over the bushes and trees way in-shore, over the fences into the adjacent fields, up or down stream, thereby losing many which landed in water or in deep grass or thick brush. Much of our time was spent chasing after those we had slung in-land, climbing trees to release our hooks, or hunting for fish which were thrown a long distance and lost.

In spite of lack of skill and our inferior tackle, we generally got plenty. The creeks were full of them and very few fishermen sought them. We ran from hole to hole and went over ground enough in an hour for two days' fishing. Close, careful or scientific angling we knew nothing of. We were not exactly "chalk-liners," but certainly not high-toned sportsmen; yet we knew all the sure holes, logs, rifts, reaches, alders and eddies that never failed to give up from one to a dozen good trout when properly approached.

When caught, the fish were hung on a long, crotched birch string, which was carried in the hand. When small I was allowed to go fishing without line, hook or pole, to carry the fish and sometimes the bait. I was expected also to act as a retriever and run after the trout that were slung over the trees or on the banks of the stream and in adjacent fields. For a few years I held this job under my brother John and others, but I always keenly appreciated the degradation, and the ambition to be a real fisherman was always burning within me; then I got mother to braid me a short line from old Dick's tail, secured a pole, and thereafter went it on my own hook. I was never as successful an angler as John, and had to "keep back" when we approached a hole where sly, old, big ones lived, unless I chose to go far ahead and be out of his way.

In early days we fished only on Deer Creek and Fox Creek. They ran close together, averaging only one-half or three-quar- 


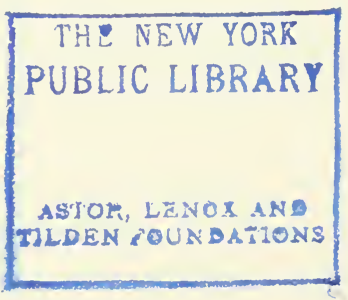




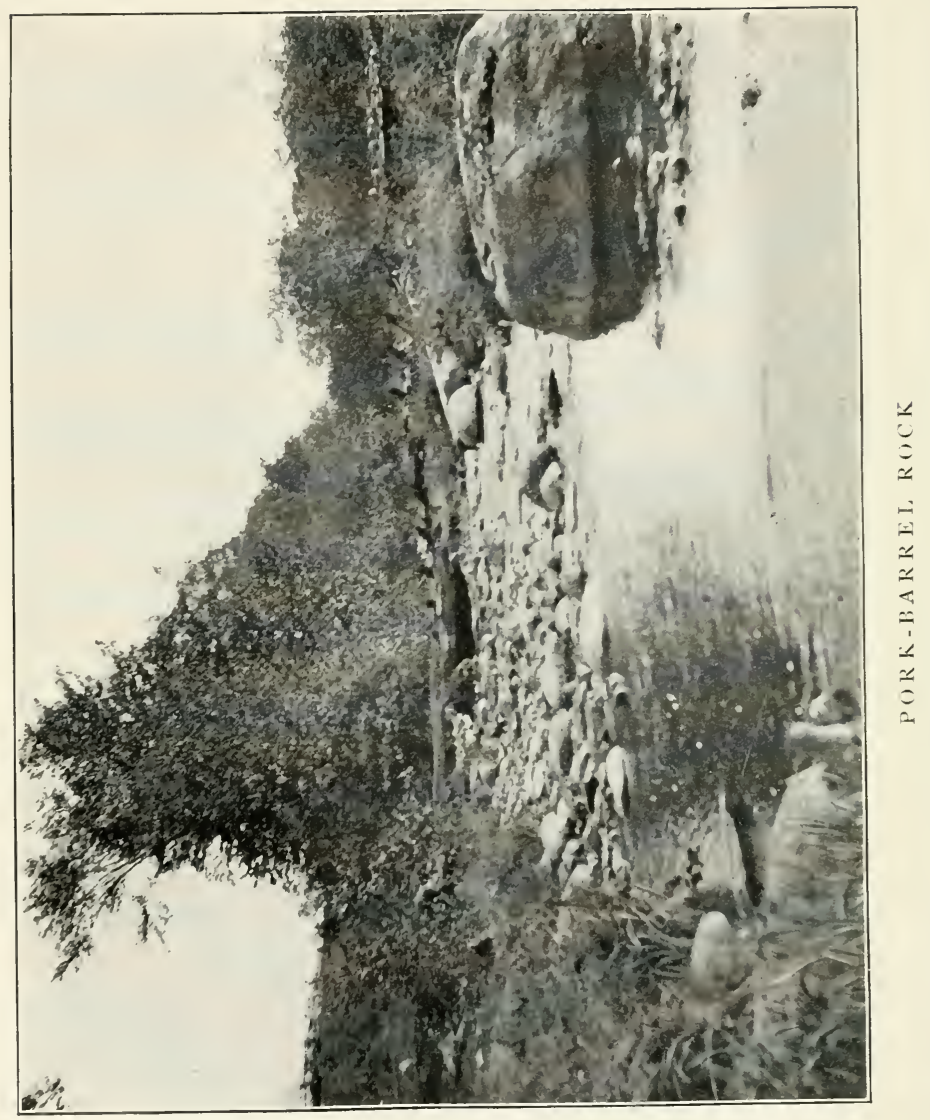


ters of a mile apart, and we could fish up one and down the other, starting from and landing near home. Sometimes we joined with the Wilcox boys, who were also fond of the sport, and all went in a big, noisy gang, either taking turns as to who should go ahead or relying upon our legs for the lead. The biggest catch made by any of us boys, time considered, was by Whitfield Wilcox.

One rainy day we were at the "ducking-hole," swimming and playing in the water. Whit. went ashore and picked up his pole, and, without dressing, took out eighty trout, weighing from three ounces to a pound, as fast as he could drop in and pull out his hook - taking them from where we were splashing and swimming about in the deep hole.

The hole under the milldam was sure for a half-dozen or more. There was a great big rock just below the milldam, with a deep hole worn out under it, which mother always called her "pork barrel," and told us that in early days, while living in the old $\log$ house, if she wanted fish, she never failed to get all that she required in five minutes' fishing from under this rock. By the big rock under the bridge by the mill, and the "floodwood" hole below the mill, were other places where we always got them. As we grew up we became more skillful and had better tackle, but had to go farther to get the fish.

John was also something of a hunter - a thing he learned from William Johnson. I never cared much for it, and after having the old gun kick the skin from and bruise my shoulder a few times, thought still less of it.

"Good swimming" was a popular amusement. From very early spring till chilly fall we embraced every opportunity to "go in"- I cannot now see why, except it was because we were forbidden to do it. We frequently stole away and met other boys, 
and, out of everybody's sight, stayed in the water to our hearts' content and until we were "blue as whetstones;" then we would go ashore and dry ourselves in the sun if there was any, and run up and down the bank and shake our heads to dry our hair so it would not give us away. In this we generally succeeded, but mother used sometimes to convict us by raising our back hair and running her fingers over our heads, at the same time examining our bare feet, which would be uncommonly white, notwithstanding we had gone through every mudhole or dirty place on the way home to bring them back to their regular color and looks.

In the fall, after thrashing, we had sport in playing "hide and seek" and "hi-spy" around our own and the neighbors' barns. We dug holes through the mows and went in and out like rats, at the risk of getting stuck or smothered to death.

Picking berries and gathering beechnuts and butternuts was an amusement combined with utility.

One little game indulged in, and one that really made us smart, was called "licking jackets," and was this: Two boys of a size each selected for himself a great bull thistle or Canada thistle, then took off their coats and jackets - if they wore any - and, taking hold of each other's shirt collars with their left hands, belabored each other's backs till one or the other caved. The signal for surrender was the word "Sim-i-si." Matches of this kind were promoted and managed by the big boys to test the "grit" of the smaller ones, and were quite apt to lead to unpleasant feelings, if not to a fight. I well remember that, up by the French-lot barn, Dwight Webb once filled my seat so full of thistle prickers that I had but little occasion to sit down for a week.

In the long, winter evenings we used to go back and forth 
playing indoor games with the neighbors' young folks. "Blindman's buff" was a popular game, for which the great big kitchens at Elder Wilcox's and at father's were well adapted. Checkers, "cat's cradle," "fox and geese" and "pin on a hat" were quite harmless, orthodox games, which we were allowed to play, although the latter was a straight gamble, as some one lost or won a pin every time the hat was cuffed.

Dice or cards we knew nothing of - at least, for a long while, and were supposed not to know still longer; yet almost every boy in the neighborhood could, and did, learn to play cards long before his parents knew it. Had they known it, they would have felt scandalized and disgraced thereby.

The boys sedulously taught one another under most adverse circumstances. John learned first-how long first, I do not know; then he taught me. The first game was "old sledge," played on the hay-mow of the big barn, where we used to feel safe from discovery. If the barn-door opened, we began to pitch down hay right away. There was never such an abundance of hay always on the floor and ready for the cattle as that spring. At the sugar-bush, when we boiled nights, was another safe place, and was one of the real reasons why the neighbors' boys were so good to come and help, which father wondered at but did not understand. I remember going to Uncle Daniel Wise's house in the winter to play with Cousins Bishop and Sidney in the horse-barn by lantern light, and, when frozen out of the horsebarn, on the coverlid after going to bed.

It was a pursuit of knowledge under serious difficulties. The cards had to be hid. Bishop kept his on a scantling cross-piece over the horse-stalls. An old, greasy pack was a treasure as well as a constant source of apprehension and danger. Just what would have happened if we had been discovered I do not 
know, but we did know that we were doing wrong - or at least what our parents thought was wrong - and, as usual, the guilty conscience made us cowards.

Sundays after church we sometimes played under the mill on the clean sawdust. One day father found down below the four of diamonds. He brought it up, tacked it on the fender-post and used it to mark some tallies of lumber on. He asked me what it was-and I did not know. Whether he knew or not, he did not say, and I did not ask. Squire Fox, coming into the mill and seeing the card on the post, sang out, "Where is the rest of your pack, Deacon? You had better take down that 'four,' or somebody will come along with a 'five' and take your whole mill."

As time went on, these radical New England prejudices wore off and all kinds of games were tolerated. Of course, like most other boys at the fool age, I tried to learn to chew and smoke tobacco. I gave up chewing, together with everything inside of me, on my first and only quid. At smoking I did but little better, and it was with fear and trembling that I tackled a cigar until long after I was twenty-one and had become a real man, instead of a would-be one.

Father used neither tobacco nor liquor and was a staunch teetotaler and temperance man, and his house and the old church building, of which he was a principal owner, were always open to temperance lecturers.

Coming to this church, I will give a short history of its building, use and final disposition, as it was one of the unfortunate things in the family history which brought toil, trouble and vexation of spirit. 
FIRST CONGREGATIONAL CHURCH IN LORRAINE "Thy congregation hath dwelt therein."

Hough's History of Jefferson County says: "The First Congregational Society in Lorraine was formed December 3, I829, with Silas Lyman, William Carruth and Alfred Webb, trustees. A small church was erected in 1830 , which has been sold to the Methodists."

The historian could not easily have gotten further from the facts. Hough was right as to the trustees of the society in 1829 , but he evidently knew nothing whatever of the church organization, and his statement as to the final disposition of the church building is entirely wrong. Haddock's History of Jefferson County simply adopts the errors of Hough and magnifies them. The historians' errors are so rank that I cannot let them pass without correction.

The people who settled the town of Lorraine were distinctively a pious, church-going people, and long before they had a regular place of meeting they had a church organization, and usually a pastor. I find among father's old books one entitled, "Records of the First Congregational Church in Lorraine." These records, written in a little home-made record book of twenty-six pages, made of very coarse, unruled paper, unbound, pinned together with an old-fashioned, round-headed pin, are formal and official, and duly attested by the well-known church officials who kept them.

From the record it appears that the church was formed in the summer of 1804 , by the Rev. Mr. Laesdel; that March I2, I 807, “Deacons Lyman and Brown were chosen and ordained; Rev. William Ruddle, pastor." My grandfather, Silas Lyman, and great-grandfather, William Brown, were the deacons men- 
tioned. November 2, I808, "Rev. Enos Bliss was reinstalled over this church and congregation," showing that he had before served as pastor.

I will give a few extracts from this church record which may be of interest, as they show its methods and management: December 3I, I809, Robert McKee, "having been guilty of the sin of intemperance, made full confession and was restored to full communion in the church." In October, I824, "Rev. Enos Bliss was dismissed from his pastoral charge of this church by the Black River Association." Dismissed is not used in an unfriendly or a discreditable sense.

Then follows a list of well-known settlers, commencing with William Brown, Silas Lyman, Timothy Risley and others, to the number of fifty-one, many of whom at some later date "took letters" and were dismissed.

Opposite the name of Brother Robert McKee stands the word "excommunicated;" also against the name of James McKee and David Webb. The rest, with some watching and discipline, seem to have got through all right. That they had their troubles is evidenced by this meager old record, which relates principally to complaints and matters of discipline, and plainly shows that they considered it their first Christian duty to remove the mote from their brother's eye and show him the error of his way.

Silas Lyman, my father, was elected deacon March I0, I826, and, together with Allen Pitkin, was "solemnly set apart to that office by prayer and exhortation." The church meetings were held at private houses. November 20, I826, they met at the house of the Rev. Enos Bliss, and "the case of Mr. James McKee was brought before the church, when it appeared that for a long time he had neglected the duties of religion and the meetings of the church, and as all the members of the church 
knew that much labor had been taken with him to no effect, and as he had been notified to attend church meetings but did not appear, it was resolved to suspend him from the privileges of the church for covenant breaking." “Electa Risley, a backslidden member, appeared before the church and made full confession and was restored to full communion." These entries signed by Rev. A. L. Crandall, moderator.

That they were not particularly bigoted was shown by the admission to the church, May I3, I827, of Susan Adams "by Baptist ordinances, administered by Rev. Abel L. Crandall."

June I6, I830, "The church met agreeable to appointment at the house of Deacon Pitkin, and, after prayer, voted to send a second and last admonition to Brother James McKee. Deacon Lyman was appointed to prepare the admonition and present it to him."

As time went on, there were many additions to the church of the children of old settlers, its first members, and communion service was frequent.

January, I836, I find this memorandum: "The church of Lorraine has had preaching one-half of the time for several years past, by Brothers Monroe, Higbee, Morton, Baker and others."

March 9, I837, complaint was made against Brother George Hitchcock for "neglecting the ordinances of the church, and also for allowing card-playing in his house and playing himself, also joining parties of vain amusements, dancing, etc." Also, complaint was made against Abigail Hart, Sally Stillman, Lucy Pitkin and Mariette Hitchcock, "for having neglected communion of the church and that they associated with vain company, joined in dancing and other vain amusements," and they were cited " to appear at our next meeting, Friday, March I 7 th, at ten o'clock A. M., at the meeting-house." March I 7th, "the 
church proceeded to act on Brother George Hitchcock's case, sustaining the complaint and ordering a letter of adrnonition sent him." Acting on the complaints against the young ladies separately, they were also sustained, and it was "ordered that the scribe send them letters of admonition."

June $24^{\text {th }}$, the church designated Deacon Freeman, Rev. Enos Bliss and Brother Loren Bushnell as a committee to visit the members who had personally received letters of admonition. July 8th, still following the same members, the committee reported "that they had visited those delinquent members, but found no signs of repentance, and as for the rest, so far as they could learn, there was but little hope of reclaiming them; whereupon the church voted to suspend them from communion of the church for three months, and if no repentance was manifested by them at that time, they be cut off from the church."

I once asked my sister Parnee what terrible crime was covered by the charge of "vain amusements" preferred against Lucy Pitkin and others, for I remembered Lucy, and knew that she was one of the best principled and loveliest of women. My sister laughed as she told me the story - namely: that Lucy and some of the other more lively girls and boys of the church had been guilty of playing the game of "snap and catch 'em," which implied chasing one another around a ring, and the one that got caught first got kissed first. However good their intentions, the church at Lorraine never was successful in eradicating these "vain amusements."

Without date is noted that Rev. Enos Bliss, Deacon Lyman and Brother Bushnell were made a committee to notify Brother Berna Van Ettan "That the church have knowledge that reports unfavorable to Christian character lie against him." The record does not show the character of these unfavorable reports, 
but from private information I learned that Brother Van Ettan had become too gay.

The last two entries in the record are dated July 6 and I3, I 843 , and relate to an unfortunate quarrel which had then sprung up between Brother Alfred Webb and Brother Robert Piddock, and, as usual, instead of making any attempt to settle and smooth the matter over, the church very promptly voted to receive the complaints and investigate the same. They had various meetings and adjournments, and finally voted "to call a council of ministers and delegates from four sister churches, in Rodman, North Adams, Smithville and Mannsville," thus extending the quarrel to neighboring towns. In fact, it seemed to be the most interesting part of their church work and duties to discipline their brethren.

The charges generally were of a trivial character, as shown by the extracts given. That the difficulty between Mr. Piddock and Mr. Webb in itself amounted to nothing if the church had let it alone, is shown by some loose papers in the case which I found among my father's. I also found a statement drawn by father and left with him, signed by both Piddock and Webb, agreeing to be good friends and neighbors, and forgive each other and live peaceably and friendly - a thing which would have happened long before had not the church helped to make " mountains out of mole-hills;" but Deacon Webb and Brother Piddock were good fighters, and when the church people ranged themselves on one side or the other, they also braced in and made a personal and church quarrel that lasted for a year or two and resulted in the complete rupture and disorganization of the institution. 


\section{BUILDING THE MEETING-HOUSE}

Having corrected the historian Hough's errors as to the church organization, I will now give the facts as to the building, its use and final disposition. The records never confound the "church" with the "meeting-house."

About I830, the church people began to agitate the question of building for themselves a meeting-house, and a subscription was started, which still exists, dated December 4, 1829, in which nine members agreed to contribute certain amounts in material and work. For instance, Deacon Allen Pitkin, a carpenter, made his subscription payable in work; Elijah R. Fox, in team work; Silas Lyman, who had a sawmill, in lumber and hardware. No one agreed to pay a dollar in money, and but two hundred and thirty dollars were pledged in all.

The builders were Deacons Allen Pitkin and Silas Lyman, and their subscriptions were one-half of the whole. They expected that the trustees would collect funds and reimburse them. With more zeal than discretion, they went on with the building, not waiting to secure subscriptions, or even to obtain title to the site. When they were about completing it, unfortunate dissensions arose over differences on the temperance question, and, in addition thereto, a very rabid anti-slavery agitation soon followed, which divided the members of the church on sharper lines than anything that preceded, most of the members being opposed to the preaching of temperance or anti-slavery from the pulpit. These jangles divided the church and so demoralized it that when father and Deacon Pitkin had the meeting-house completed and ready to turn over, there was nobody to take it - at least nobody to pay a dollar for it. The pro-slavery element was strongest, and they punished Deacons Pitkin and Lyman by letting them 


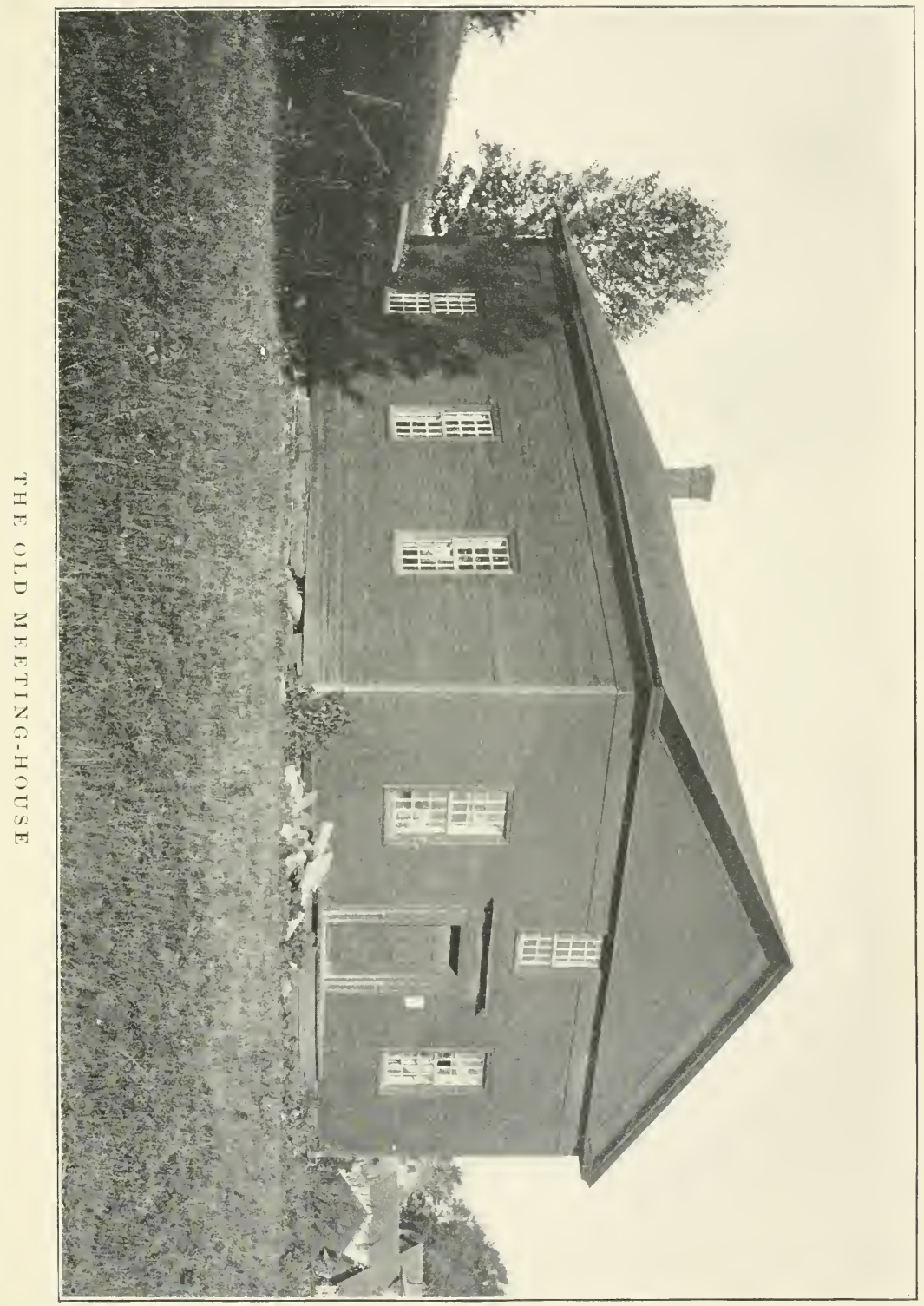




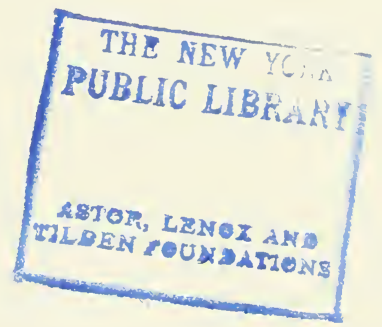


pay for their anti-slavery and temperance heresies. Although the building was too strongly tainted with these political heresies to be paid for, they continued to use it through the remainder of their moribund existence as a church.

Just what the building cost I am unable to state, but perhaps from fifteen to eighteen hundred dollars, which was then a great deal of money, and to Mr. Pitkin and father meant debt and embarrassment for many years. Who got the most money into the unfortunate venture I do not know, but suspect it was father, for the reason that he always assumed the management and control of the property, and I know he would not have done so or been allowed to do so unless he was a majority owner.

To square up the debts which had been incurred in its building added to the mortgage already on the farm, and was a source of trouble and discomfort to the whole family for many, many years. It was not an easy thing to pay off debts in those days, with cheese at five cents a pound and butter at twelve and one-half cents, and interest at seven per cent. That debt lasted until our parents were both broken down, and until all the children had a chance to help in its payment. It was a foolish move, actuated by religious zeal and public spirit, of which mother never spoke with any sort of complacence or resignation.

The old churchless meeting-house became quite an institution in its way, and obtained quite a reputation. It was always open for temperance or anti-slavery lectures, which could not be said of the hide-bound regular churches of the town. For many years the Methodists had no church of their own and were allowed to use this, on what terms I do not know. They probably paid little or nothing, for the reason that father always kept control and opened the doors to all itinerant reformers, revivalists, singing schools, concerts, exhibitions and "moral shows" 
that came along, and in addition to free rent, generally gave them fire and lights.

In 1858 , together with the heirs of Deacon Pitkin, he gave the same to the town of Lorraine for a town hall, for which purpose it is now used; and the same year I find a deed from Aaron Brown to the town of Lorraine, conveying for fifty dollars forty-one and six-tenths perches of land, called "the Presbyterian meeting-house lot," undoubtedly meaning Congregational meeting-house lot.

It was a favorite place in which to hold revivals, and eminent revivalists conducted operations there, among them the famous Jedediah Burchard, who relied upon working up his audience to a pitch of excitement that enabled him to do anything he chose with them. One night, when he had them under excellent control and had almost everybody on the anxious seats, he looked up to the gallery and ordered the singers to come down, which they did - all but Cal. Gillman; he was a very tall, darkcomplexioned man whom it was not easy to hypnotize. Cal. was leaning against a post or small pillar running from the front of the gallery to the ceiling, and with apparent curiosity was looking down on the kneeling and wailing crowd below. Burchard saw him, and shaking his long, bony forefinger at him, called out, "Cal. Gillman, you black devil, come down out of that gallery; you look like a stack-pole stuck up in hell; come down here and get on your knees." Cal. did not come.

Many a long, weary Sunday have I spent in that house. The services then were very lengthy - two long sermons, and Sundayschool between. There was no escape; we were required to go and sit in the long, deep pew, with father sitting next the door. The noon intermission was a little let-up, had it not been for the Sunday-school with its long lessons, which I had to stay and 
hear, whether in a class or not. Of course, when we boys had grown to a size that we dared absent ourselves at noon and go down in the gulf for swimming and gathering wintergreens, it was not so hard.

Some very famous preachers came occasionally to give us one of their old sermons with innumerable heads, written when they were at college. Father Speer, of Rodman, and Elder Walker, of Adams, are two whom I remember especially well, because they were white-haired, kind old gentlemen who frequently visited at our house and seldom mentioned hell - a place very popular with clergymen and many others in those days, but feared and dreaded by children and others who were unable to understand the philosophy of it.

In this old church some very famous anti-slavery speakers were also heard - Ward, Logan and others that I cannot now remember. Father was a strong anti-slavery man from the earliest days of the agitation, and was ready at any and all times to discuss the subject with any one who desired. These discussions were sometimes quite exciting, for it was a political question then as well as a moral one, and very good neighbors and close friends for the time being became bitter enemies, while they angrily argued the right and wrong of the institution.

Father believed that continued agitation of the matter would finally bring about the desired reform. He did not expect to see the great crime of slavery, against which he prayed every morning for three hundred and sixty-five days in every year, for over fifty years, abolished, but often said that if I lived to be his age I might see a change in public sentiment on the question which would lead to abolition or emancipation. Yet he did live two full decades after the evil which he had fought for half a century had been wiped out in blood. 
He was an acquaintance and friend of Gerrit Smith, and his house was for years an underground railroad station, and he did considerable by way of forwarding fugitive slaves to Canada.

One Sunday morning I was told that I could stay at home from church with mother. I was completely surprised but wonderfully pleased. I had a job on hand which this gave me an opportunity to complete. I had erected a water-power of my own on a little brook beside the road where the water leaked from the mill-trunk or barrels. I needed some wheels and gear to perfect the machinery of my mill. In the garret was an old, old clock that I had already dismantled and robbed of much of its running-gear. As soon as they had all got into the big double wagon and left the south end of the piazza, which was used for landing and embarking passengers, I started upstairs. To reach the garret we used a short ladder from the upper hall to a sort of skylight hole covered with a board. I was climbing up through this hole when, glancing to the west where the light came in through the gable-end semi-circular window, I saw a great, big, fat, colored woman trying to straighten out the kinks in her hair with a metal comb.

I was more than scared, and although I had seen negroes before, was not looking for them in that garret. Without stopping to say good morning, I went down the ladder as lively as a squirrel, and went to my mother and reported what I had found. She quieted me, and told me that she knew the black woman was up there - that she had been there for a day or two, but was to go away soon.

Sleep was slow in coming that night, and for months when I went upstairs to bed I cast my eye up toward this hole in the garret, expecting very likely that a big wench would drop down 
on me. The fear of what might be going on in that line about the premises did not contribute to my peace of mind or soundness of sleep for quite a while after that.

\section{3}

\section{THE CHOIR - DONATIONS}

In the days of which I write church music was furnished by volunteers, but the character and kind were not lowered by this fact. It was considered a great honor to be selected as one of the choir, and no one obtained this distinction unless he or she had been through a thorough course of study and training as taught in the singing schools of the day, and in addition had a good natural voice, was able to read music readily and to sing any ordinary piece at sight. All my sisters were singers, and while at home took part in the church music. Sister Amanda sung for many years in the various choirs of the town, and later Antoinette, my niece, who lived with us, took an active part in choir matters with the younger set. There was more or less contention, rivalry and dispute over the music-more, even, then than now, for, as none of the singers received any pay for their services, they felt entirely free to express their minds about it.

The leader of the choir was usually selected from among the best tenor singers. His place was at the head of the line in the front seat of the gallery, just over the preacher's head. Another position that was much sought after and considered of great distinction and honor was that of leading lady singer; she was usually the best, or one of the best, treble singers, and choir troubles were quite apt to come up when deciding upon this leading soprano. It gave her a right to a place in the front 
line of the gallery seats next to the chorister, and she was looked upon with envy, not to say jealousy and malice, by all the other ladies in the gallery and very many in the congregation below. Bitter personal feuds that lasted for a lifetime came from the fierce competition for these positions.

Sometimes there would spring up rival factions, and each one would have its choice for chorister. These disputes were generally settled before the rupture was open and disgraceful, but occasionally the trouble resulted in an open split in the choir and the election of two choristers. Then there was trouble indeed, and it was not confined to the choir alone, but was taken up and participated in by the whole congregation.

I remember one occasion when two choristers jumped for the head of the line at the opening of the services, like two rival chairmen at a political convention, and came to a clinch in the gallery, just over the minister's head. One was Mr. William Fassett, a well-known, popular gentleman of the town, and the other Mr. John Waite, a man of standing and character, but having just enough John Bull in his make-up to allow nobody to usurp what he thought to be his rights. Fassett was the stronger of the two, and in the clinch was about to drop Waite over the gallery railing onto the head of the minister in the pulpit below. Waite was not prepared for this, and rather give up his place in the gallery than to be landed in the pulpit with the preacher, so cried out, "Be'ave! Mr. Fassett, be'ave!" Mr. Fassett did "be'ave," but Brother Waite had to take a back seat thereafter.

The donation was an occurrence to which all looked forward with pleasure. It was the one gathering of the whole winter that brought all the good people together. The attendance was not confined to the members and patrons of the church presided 
over by the beneficiary. Doctrines and lines of religious demarkation which were sharp enough to divide Christians at the communion table disappeared when it came to the donation, and all met there in a spirit of fraternity and brotherly love.

They all brought their little contributions for the benefit of the minister and his family, and they were much more likely to be in some article of household supplies or wearing apparel than in money; but, whatever the gift, it was that of a "cheerful giver," and they were not criticised on account of its character or value.

The donation was a principal item in the yearly support of the minister and his family. In the early days the ministers or clergymen who presided over country churches calculated to and did partially support themselves by some useful profession or labor. Elder Walker was a surveyor and conveyancer of great skill, and his services in that line brought him a considerable portion of his income. Rev. Enos Bliss and Rev. John Bishop were farmers. They labored in their own vineyards for daily bread and in the vineyard of the Lord for the love of His cause.

The donation to the young people meant still more than to their parents. It gave them the opportunity of the whole winter to meet and frolic and play among themselves in a semi-pious but most enjoyable manner, without being criticised for the samebecause it was, you know, at the donation party. Their most lively frolics generally came after the older people had gone home-in fact, the older people commonly attended in the afternoon and the young ones in the evening.

To show how the annual donation was understood and appreciated by the young people, I must relate a little episode that occurred in the family of my brother-in-law, Mr. Doane. They were all getting ready to attend Elder Salmon's donation, but for 
some reason Satira was told that she must stay at home that evening. This gave her great pain, and she began to cry most piteously. Her father said, "Satira, I am ashamed of you - to make such a fuss!" Heart-broken and sobbing, she answered, “Well,_I-can't-see-why-I-can't-go; - everybody-else - goes, - but - I - never - went - to - a - donation, - nor - a -circus-neither."

\section{3}

\section{RELIGIOUS PRIVILEGES}

One might suppose that, living on a farm and a long distance from a church, the religious privileges, so-called, would be very poor. Such, however, was not the case. The settlers of the town of Lorraine were all New England people of Puritan, Protestant stock. They had strong convictions as to right and wrong, and were earnest in their professions and beliefs.

In another place I have given the history of one of the churches of the town - the Congregational; but there was also a Methodist and a Baptist church from the earliest days that I can remember. The church membership included a good share of all the people. There were few Catholics or Episcopalians in the whole town. The churches sometimes united in conducting what they called "union services," generally when there was a revival in progress. Prayer meetings were very common, particularly when the evenings were long and the people had leisure.

Singing schools were also conducted on a sort of mutual or non-sectarian plan. By the young people singing schools and prayer meetings were attended as amusements. They gave fine opportunities to meet and visit, and to the young men of suitable age for that kind of business it was particularly agreeable, as it 
gave them a chance to extend their acquaintance and to go home with the girls. Besides all this, these prayer meetings and singing schools were both very respectable and moral institutions, to attend which it was only necessary to ask permission, and to take a lively interest in them was to be in society.

In the early days the prayer meetings were held at the neighbors' houses, first with one and then another, and were very interesting outside the religious features, frequently leading to good-natured debate among the older people. People in those days were not contented to swallow a creed and adopt beliefs without at least talking about it. They did swallow their creeds and blindly accept their beliefs beyond any degree that the same is done now, but on the slightest criticism or suggestion a debate or controversy was at once opened.

Night after night Elder Wilcox would pace up and down our long kitchen, gesticulating and arguing with father, who sat in his chair tipped back against the old brick oven. Their favorite subject of contention was "free will" and "predestination," Mr. Wilcox holding strongly to the Presbyterian theory, while father combated him on a sort of modified ground. They always finished where they began, agreeing that it was a mystery too deep for human understanding.

In our home we always had Bible reading and prayer every morning immediately after breakfast. It was father's early custom to take chapter after chapter in succession, going through the Bible by course, but as time went on he skipped about, leaving out the uninteresting parts of the Old Testament that he might have time to read the writings of the disciples or take up something from Job, the history of Solomon, the sweet songs of David, or other of the better writers. Sometimes, if the chapter had something especially interesting in it, it was followed by a 
little talk, which was quite apt to develop difference of opinion in the family circle as to the proper interpretation and application of the gospel teachings. We learned very much more of the Bible by hearing this constant reading than from any Sunday-school or church attendance.

Father had great ability in making a good, practical prayer, and never slighted the same, although not tediously long. $\mathrm{He}$ was not accustomed to use parrot phrases, but, as a matter of course, fell into certain general formulas, which I remember pretty well, when petitioning for certain things, like the abolition of slavery and intemperance. During prayer time we all remained quiet and orderly. When a young chap mother used to keep me very close to her-I suppose, with reference to keeping me quiet and well-behaved.

An occurrence connected with this regular morning devotion I shall always remember. Bernice Doane and some of his family were at our house. Father was reading the Bible as usual, and, as frequently occurs with small boys, I took the occasion to show off a little, relying upon the fact of there being company to protect me.

I got down out of my chair and shuffled and moved about. Father looked over his spectacles at me and then went on with his reading. Bernice had his hands and fingers partly over his eyes and smiled and winked at me, and I thought I was doing firstrate, so I went a little farther from my chair and sat down on the floor, making considerable noise. Father finished the chapter and shut the old, black Bible with a kind of snap that was unusual and boded trouble. He laid the Bible on the window-sill, where it was always kept, and, walking over, took me by the collar with the left hand, put his left foot up in the old wooden-bottomed chair in which I was supposed to sit, drew me over his knee and 
gave me about a dozen blows with his bare hand in the place where they would do the most good. His was not the soft hand of pampered luxury. I was surprised, and felt injured in the extreme, but never whimpered, and he never spoke a word, but sat me down in the chair cachug, then walked over to his own chair and dropped down on his knees, and, for a man that must have felt so thoroughly provoked, made a most eloquent, kind-hearted prayer, not forgetting "the down-trodden and oppressed of all nations." I dropped my chin and looked at the floor for some time. For a few minutes I realized who were the oppressed and down-trodden, and also wished they might be set free from further trouble. When I dared raise my eyes Bernice was still looking through his fingers at me and fairly chuckling with glee, and he never forgot to his dying day to refer to the matter whenever there was a good chance to recall it for my benefit.

This was the first time father had ever struck me, and the only occasion except the "crooked frow" case, when he taught me not to use the word "hey." Years afterward, in talking the matter over, when I asked him why he had given me such an unrighteous spanking for nothing, and why he did not even deign to tell me the reason for doing so at the time, he assumed not to remember it very clearly, but said, "If you didn't know what it was for at the time, you never will." 


\section{SPINNING AND WEAVING}

"She layeth her hands to the spindle, and her hands hold the distaff; She maketh herself coverings of tapestry; she is not afraid of the snow for her household."

Keeping sheep was a necessity in the early history of the farm, as the home manufacture of woolen cloth of all kinds was an industry which could not be dispensed with. There were no butcher shops in the country, and the meat required by the family had to be produced on the farm. Mutton and lamb were articles of food much liked and very wholesome. We did not keep large flocks, but a sufficient number to supply the wool and meat needed for home consumption. Sheep were allowed to run loose in the yard and under the sheds in the winter, and in the summer sent to the pasture.

After shearing, the wool was sorted and picked over, to separate the different grades as to quality and fineness, and greased with melted lard or whey butter so as to make it spin evenly. It was then sent to the carding mill and made into rolls about two feet long and one-half inch in diameter, when it was ready for spinning. The yarn, when spun, was colored to suit the kind of fabric desired.

In the house was a good loom and all the appliances for making any and all kinds of cloth desired, from the coarse horseblanket to a fine shawl; from rag and woolen carpets in fancy stripes to fine blankets, made in colors and fancy patterns. The house was kept well stocked with the products of this loom in many qualities and of such styles as were most useful: "Hard times," a heavy cloth for every-day wear; "kerseymere," which was woven in a double harness and the wool all thrown on one side, and a fine cloth called "full cloth," which, when dressed 
and colored at the fulling mill, made a nice article for the "best clothes" of the men.

There were three spinning wheels and plenty of girls to run them, and the yarn for a forty-yard piece was quickly spun. Mother had learned to spin when so small that she required a wide, low bench to bring her up high enough to turn the big wheel, and our oldest sister, Irene, began in the same manner. Mother was an expert spinner and weaver, and all her girls were well taught in that line, and when they left home each had a nice lot of home-made goods of her own manufacture. Some of them had the conceit to believe they could weave as well and more fancy patterns than their teacher.

At sister Parnee's, in Wisconsin, I once slept in a nice chamber room covered with a yarn carpet which she had made with her own hands fifty years before. The colors were unfaded and the texture unbroken, although used daily for half a century.

The loom, with its various implements, had the right of way all over the house, and, if the work and circumstances required, was as apt to be found in the parlor as elsewhere. There were big wheels, fine wheels, little wheels, flax wheels, and a quillwheel; reels, warping bars, scarns, spool-racks, harnesses and pattern drafts - all supposed to be found and kept in the chamber over the woodshed, but in fact traveling around the house according to the pleasure of those who used them.

There was no excuse for any one to be idle, as this was a work that could be taken up and dropped at any time. All the cloth required for the plain and much of the finer clothing of the large family, the hired help, and frequently some for neighbors and others not having the tools or knowledge to make their own, was thus made with little cost except the labor.

Dyeing and coloring was an important branch of the cloth- 
making business, and required much knowledge, skill and good taste. Some of the dyes and coloring materials were homemade, but answered every purpose, often proving better than the purchased dyestuff.

The woolen goods were of the most importance and greatest value to the family, but the flax work was the most interesting, and the linen goods could not be neglected.

The manufacture of fine linen for clothing, for tablecloths, napkins and various other uses, was the most delicate, highclass work in the line of home manufactures. I will not undertake to follow it in close detail, but will give the methods followed in as few words as possible.

To obtain the necessary stock, a field large enough to supply the same was annually sown. On good land flax grows about two feet high, and in bloom is a very pretty sight, being a mass of sky-blue blossoms; when ripe, each stalk has a large number of little bolls filled with seed. In the fall it was pulled by the roots from the ground and bound in very small bundles in order that the seed might quickly dry.

When dry it was taken to the barn and a large, round stone placed in the middle of a blanket on the barn floor. The blanket was used to save the fine seed which would otherwise run through the cracks in the floor. Taking one bundle at a time, it was pounded on the stone with a wooden mallet and whipped and beaten over the stone to get out the seed and break off the little sprangles and roughness. It was then drawn to the flat near the creek, or to some other smooth, grassy ground, unbound and evenly spread out to rot. The rotting was to get rid of the woody center of the stalk, the outer covering or fiber being the part required to make thread and cloth. It had to be watched closely while rotting and occasionally 
turned over, as it was liable to injury while going through this process.

When sufficiently rotted it was dried and taken to the barn, ready for the "break." This was a simple machine, consisting of one piece of hardwood board or plank raised by hand and jammed down between two other pieces arranged on a bench so as to be easily worked. When the flax was laid across this and the break worked vigorously, it came out so bruised and broken that the fiber was released from the shive or shuck of the stalk. Breaking flax was heavy, disagreeable work and raised a nasty dust. It required a good, strong man, and sometimes one was hired, either by the day or the job - father said the break told which. It could be heard chugging away for a long distance, and if worked for a per diem would say, "By the d-a-y, by the $\mathrm{d}-\mathrm{a}-\mathrm{y}$, by the d-a-y, d-a-y, d-a-y;" but if by the piece it would talk out sharp, "By the job, by the job, by the job, job, job."

Then came swingling, which was done with a sort of wooden sword with a straight blade, with which the broken flax was pounded. This cleared away the shuck and separated the coarse or swingle tow from the fiber. This coarse tow was saved and used to make tow-strings, small ropes and for wadding and packing.

Coarse hatcheling was the next process, which was drawing a handful of the fiber between a lot of sharp spindles placed in a board, doing up each hank in a separate twist when done. The result of the first hatcheling was to comb out the coarse, short fiber called tow. Then it went to the house and was put through a fine hatchel, which left it very fine and silky, ready for the distaff, upon which it was wound loosely by holding it in the left hand and turning the distaff, which had been temporarily detached from the wheel, in the right hand. 
It was then ready for spinning. This was done on what was known as the flax wheel, of which a few may be seen in the parlors or halls of rich people to-day, who are proud to relate that their ancestors knew how to use them. A smart spinner could make three ten-knot skeins a day, which was enough for more than two yards of cloth.

The tow was saved and made a good coarse cloth which was very much used for summer clothing.

Putting in and starting a piece of fine linen cloth was quite an intricate job. The warp had to be starched and dried, run onto large spools, which were set in long rows in the scarns; then, taking all the ends together, it was run off the spools onto the warping bars, thence run or wound on the big yarn-beam of the loom. From this it was taken one thread at a time and drawn through the eye of the harness, back and forth, until it was all drawn in; then it was put through the reed, two threads in each space, and the reed adjusted in the lathe, the thread ends all tied on the rod of the cloth-beam and the lower harness tied to the treadles. All this done, the weaver, with the shuttle which she holds in hand loaded with yarn wound on a quill, seated on her basswood seat in front of the loom, is ready to begin the work. The shuttle, thrown with the right hand, slides through between the open threads of the warp and is caught and thrown back with the left, the treadles which control the harness being worked by the foot in exact time with the throw of the shuttle and the swing of the batten, which drives home and adds thread by thread to the woof. After weaving, the cloth was usually bleached by putting it alternately in the sun and dew.

The earliest history of the world makes reference to this work. King Solomon in his writings highly commends the housewife that "seeketh wool and flax and worketh willingly 
with her hands," and whose "own works praise her in the gates;" but times have changed, and if the wise old king should come back now looking for the model woman he so highly praised and admired, he would probably find her down town on a bicycle instead of at home making the "fine linen" which was so popular in his time. Instead of "laying her hands to the spindle and distaff," she now handles the "driver" and the "putter" at the golf links.

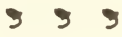

\section{THE DAIRY}

After the farm was cleared up, or partially cleared up, and the potash and mill industries had waned, and the farm, which was once paid for, through the vicissitudes of too much outside business was again mortgaged, more attention was given to the legitimate business of farming.

Lorraine was better adapted to dairying than anything else. About the time of my first recollection our people had a dairy of twenty-five or thirty cows. Dairying could be carried on without the employment of much outside help, and the profit that came from it and all other farming was practically the simple earnings of the family. In this farming has not changed; if the farmer does his own work he will make something. It requires one dollar and fifty cents worth of work to get a dollar. If the labor is hired, it is easy to see how the farmer comes out.

The care of the cows and rearing of calves and management of a dairy requires good judgment, close attention and hard work. The product, however, is always salable for cash, and the establishment of dairies was the thing which first brought money to the town and began to make the farmers independent. In 
those early days of which I speak, more particularly from 1840 to I 855 , cheese was very low - from five to six cents - but whatever it did bring, was ours. Every one about the house and farm knew how to milk, and helped. Milking was done early in the morning and late in the evening - a thing not so good for the cows or so productive of a large and even flow of milk, but it put the milking out of the way of other work.

We did not have blooded cows; they were all grades, most of them raised on the farm. Some were famous milkers, some very ordinary. The cheese was made at home, with home-made utensils and by primitive process, but its quality and flavor I have never seen excelled.

The method was as follows: The evening's milk was strained into the big cheese-tub and left standing over night. In the morning it was skimmed. Then the morning's milk was added, together with the cream taken off, which was dissolved in heated milk. The cooking of the milk was done by heating it in a large Russia-iron pail set in a big kettle or boiler on a stove that stood in the woodshed, which was the room used for the manufacture of the cheese. Sufficient rennet was added to cause it to curdle or coagulate, and the whole thoroughly stirred together.

All this was done before breakfast, and the tub covered with a large strainer cloth. Immediately after breakfast, or as soon as the coagulation or thickening of the milk was complete, it was broken or cut up into small squares, for which a long, wooden blade was used, then left to stand awhile for the whey to separate. A strainer cloth was then thrown over it and some whey dipped into the boiler and heated. This hot whey was then carefully put into the tub, gently stirred and left to stand another half-hour.

It usually required three heatings to properly cook the 148 
cheese. The curd was then dipped out into a strainer cloth laid over a rack in a sink standing on a whey-tub, to drain and cool. When cool, the curd was measured back in to the cheesetub and salted - one teacupful of salt to three gallons of curd. It was then put into the wooden hoop, in which was laid a strainer cloth, to be pressed.

The press was a rude concern, made with a long beam upon which, in wooden hoops, was hung a big rock, which was raised up and down by means of a long lever when putting in and taking out the cheese. An additional squeeze was put on by placing a springy stick from this beam up against a floor timber overhead and pulling it along the press beam, thus getting more pressure than the rock alone would give. After dinner the green cheese was turned in the hoop and bandaged with thin cloth and again put under pressure until the next day.

The cheese made in the manner I have described was soft and required a long time to cure before fit for shipment. It was kept on smooth benches in the darkened cheese-house, and greased and turned daily and cared for all summer, the whole product being sold in the fall, generally about the last of October. In early times it was packed in basswood casks holding four or five each, and drawn to Sacketts Harbor or Port Ontario, to go by water to New York or elsewhere.

Out of the cheese money came the funds which were appropriated for taxes, payments on mortgages, land contracts and other debts that must be met without fail.

Dairying also resulted in having plenty of milk, whey and swill with which to feed pigs and calves, the raising of both of which was a profitable item, and every season we were supposed to have a nice bunch of young cattle to sell, either yearlings or two-year-olds, or perhaps both. 
Butter was made in the spring, so as to have plenty of milk for the feeding and raising of calves; also considerable fall butter was made after the flow of milk was not sufficient to warrant making cheese. The thought of that old, red, revolving churn makes me tired. Often the churning was put off until evening, or, if possible, until a rainy day. The churn turned hard, and sometimes it seemed as if the butter would never "come." Father's inventive genius finally helped us out of this trouble. By an ingenious arrangement with two wires he carried power for churning from the mill. Then the contest was between the creek and the cream, and the butter could "come" when it got ready.

Just why it is that farmers cannot now make anything with cheese at from eight to ten cents, and butter at twenty-five cents, I cannot understand, for I know that we made moneyat least, saved money - when much lower prices prevailed.

There were many things of interest in the dairy work. The cows all had names, and each had her peculiarities and habits. Some were good-natured and always patient, kind, orderly, and honest, easy milkers, and great favorites; others were quicktempered, unruly and treacherous, kickers, jumpers, and generally disagreeable. Their traits were very surely inherited by their calves, and on the standing and reputation of its mother the calf was judged, with little or no care as to its sire. The old adage that "a bad cow may have a good calf" was not considered safe to act on in selecting calves to rear, and many a poor, innocent-looking, little bossy was deaconed because its mother had a bad reputation. The calves not required for raising were wasted, being killed when five days old, and nothing saved but their skins and rennets. Their carcasses were sometimes used as bait to shoot crows from, down back of the long, barnyard shed. 
Teaching a calf to drink was sometimes funny and sometimes not--all depended on the calf. If he took to it naturally and supped up the warm milk slowly while he gracefully wiggled his tail and mildly bunted his approval, it was all right, soon over, and his transfer from mother's milk to skimmed milk was successfully and peacefully accomplished. The chances were against such good luck, and the average calf made a sharp struggle before adopting this new and unnatural method of taking his dinner; but he had to come to it or starve, no matter how loudly he bawled. His head was forced into the pail of milk and held there till he choked and strangled and blowed and bunted the milk all over the stable. He would thus get the taste of the milk, then we would wet our fingers in the milk and put them in his mouth. This was a pleasant surprise, and he would begin to suck and swallow, and again choke and splutter and get mad, and sometimes bunt the pail bottom-side up. A contrary, fool calf would be a week weaning and learning to drink, and if within hearing of its mother, would make her so nervous and crazy that she was of little use till the trouble was over.

The occasion which most sorely tried one's patience was when dressed up, ready to go to church or elsewhere, to have the vicious little beast bunt and blow greasy milk all over your black pants and satin vest. Many a backslidden rural Christian can trace the moment of his downfall to the Sunday morning he lost his temper and became shamefully profane in trying to teach a calf to drink. 


\section{THANKSGIVING}

"When Summer is mislaid and lost among the leaflets dead, And Winter, in white words of frost, has telegraphed ahead, ' $T$ is then good prosperous folks display a reverential cheer, And thank their Maker one whole day for all the previous year."

Holidays were few, being Christmas, New Year, Thanksgiving, Washington's Birthday and the Fourth of July. Of the whole list, Thanksgiving Day was the only one that was always respected and observed at our house. It meant an annual gathering of the whole family, children and grandchildren, and in the early days of my memory they were all able to be there; later they moved away and scattered to different parts of the Union. Services were usually held Thanksgiving morning in the church at the "Huddle," and we attended if the roads were not too bad, but the real interest and pleasure of the day was at home.

The preparation for Thanksgiving was an elaborate one, a big dinner being the great event of the day. The principal dish was chicken-pie, which required for the baking two twelve-quart milk-pans, one for each end of the table, which was loaded with all kinds of good things known to country cooking. I will not undertake to describe the Thanksgiving dinner at home; it is beyond my ability to do the subject justice. The tables were lengthened so as to accommodate at the first table eighteen or twenty people; this, of course, left the children to be provided for at the second table. That was a long, anxious wait, and it seemed that the old folks would never get through and let us have their places.

Being the youngest of mother's family, I was always assigned to the second table with the grandchildren, some of whom were nearly my own age. While these older people enjoyed their 
Thanksgiving dinner and talked over present and old times, we children were in the south room and parlor trying to amuse ourselves, an effort never very successful, because our minds were in the kitchen with the long dinner table.

After the Thanksgiving dinner was over, the kitchen was cleared for "blind-man's buff" for the little ones, while the elder people went into the parlor and organized themselves into a choir for singing. The singing which they did was of the kind to command attention and be remembered. Father was an extra good, well-trained tenor singer; so was John. Bernice Doane, Willard Huson, Jerry Gardner and Henry Allen were all good bass, while the girls took the soprano, then called treble, and alto. William Johnson, who was an all-round singer and instrumental musician, helped, before he went away West, to make these annual concerts a great success by the aid of an old melodeon, which he held in his lap and worked up and down like a blacksmith's bellows, while Jerry played the flute. Each and every one of them was a first-class, independent singer, used to singing in public as well as private. It was solid enjoyment to them and a rich treat to listen. They fairly raised the roof of the house as they went through the old-fashioned tunes, the words of which I can remember much better than the names: "Joy to the world, the Lord has come! " "All hail the power of Jesus' name, let angels prostrate fall;" "Your harps, ye trembling saints, down from the willows take;" "The morning light is breaking, the darkness disappears;"

"While shepherds watched their flocks by night, all seated on the ground,

In wild dismay the guards around fell to the ground, fell to the ground, and sunk away;"

with the soft and plaintive, "Mary to the Saviour's tomb;" "Stay, thou insulted spirit, stay;" "Why do we mourn depart- 
ing friends?" and scores of other well-known church melodies. Their repertoire covered all the solid old tunes, hymns and anthems, the best the world has ever produced, always ending up with "Old Hundred." This family concert was usually closed by ten o'clock in the evening, and was followed by the passing of big pans filled with apples, of fried cakes, cheese and pie, and anything else that was handy, left of the wreck of the Thanksgiving dinner, including cider, if it was not yet hard. These annual gatherings were a kind of solid enjoyment among families and relatives which, unfortunately, the change in the times, customs and styles has nearly driven out of existence.

\section{3}

\section{THE SAWMILL}

The mill made a large amount of work every spring and fall and in the early winter, and helped to keep us all busy when nothing else was doing. In the early days, when the woods covered the face of the country, old Deer Creek furnished plenty of water the year around; but as the country cleared up and dried up, it became a spring and fall mill.

It was handy to have plenty of all kinds of lumber, but I doubt if it ever paid. During my knowledge of its operation it cost three times more in repairs, rebuilding, changes and running expenses than its earnings came to; no books were ever kept showing mill accounts so separated and classified as to enable one to tell the results. I know nothing of the upper or old mill and its operation except by hearsay and what I find in the old books, as it was built in 1823 and 1824 , worn out about 1838 or r 839 , and the new one built in 1842 and 1843 . My memory of 


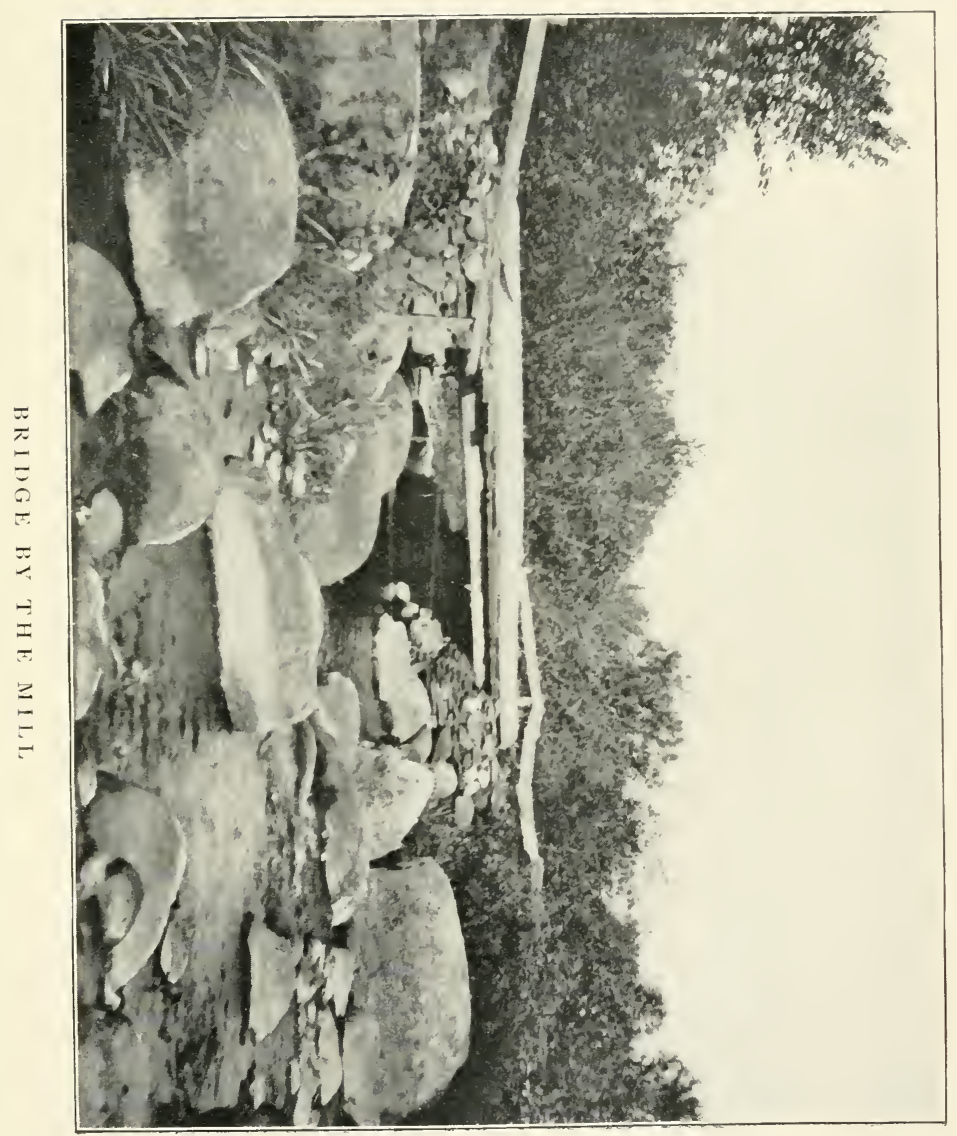




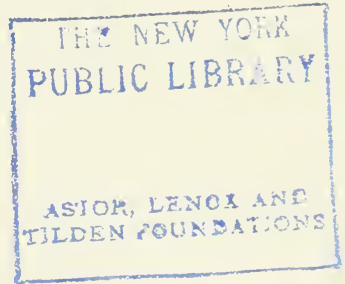


it is that of an old wreck and ruin, both mill and dam. The decrease of water and the insecurity of the old dam, which frequently gave way at its south end, suggested building the new mill; so a four-foot dam was built across the creek near the old potashery, which turned the water into a ditch from twelve to forty feet wide, leading down and across the old, stony pasture, and brought it to the north-and-south road near the corners.

A big, round trunk, called "barrels," conveyed the water across the road and into a big, high flume, giving sixteen or eighteen feet head. To build the ditch was quite a task, as it was through a bed of big boulder rocks embedded in the hardest kind of clay cement. In the removal of these rocks and in the plowing of this hardpan clay a very fine team of horses - one brown and the other gray, known as Tom and Dick - were both made blind by being overdrawn.

The fit-out of the new mill, which was completed in 1843 , was the old "flutter wheel," which was simply flat boards or blades made of hardwood set into a shaft, on the end of which was a crank from which the pitman connected directly with the gate or saw-frame - the cheapest, oldest and simplest wheel and arrangement known for water mills. I remember when it was taken out, in I846, and a "March" wheel-a direct-issue wheel with a scroll - substituted. After getting the "March" wheel in, some one had to be paid five dollars for the right to use it. This ran till 1852 , and then came the "Ferguson" side-issue reaction wheel, when a new flume and general overhauling was required.

All of these wheels took oceans of water to run them, and as the water became scarce, father was looking for something to which he could change that would run with less water. In I 855 he rebuilt the mill and flume and put in a big breast 
wheel with gearing, with a long, wide belt to drive a "muley" saw. It took a year's hard work and fifteen to eighteen hundred dollars to make the change, and when completed the mill was not what he had hoped for, and would saw no more lumber in a day than before the rebuilding, and not as much in a year. It froze up easily and early, and was difficult to thaw or cut out. Indeed, by that time there was not a great deal of lumber to be sawed, as the mill was a custom mill and the country round about had become pretty well cleared and built up.

Still later he put in a circular saw and made other changes, which took all the money he could raise, and then sold it for a few hundred dollars. Whether the mill ever paid or not, it made a heap of heavy, hard work. When logs were plenty, which they were for the years when I was very small, every winter the mill-yard and even the highways about the corners were filled with logs, which were often piled high upon each other. A sawyer was then employed to help run the mill, or sometimes to saw by the thousand, he hiring somebody else to help him saw nights.

In the early days of the mill brother Gilbert had charge of it and gave the most time to it of anybody. William Johnson, who subsequently married sister Sarah, lived in our family for several years while a boy, and as soon as old enough was extensively employed in the mill. He was a young man of energy, with great inventive and mechanical genius, and got his first practical lessons in the manufacture of lumber in this old mill. From it he went to the pine woods and worked for quite a while in the Ferguson mill, above Richland. He then went West, and finally to Minneapolis, where he engaged as foreman and manager of a lumber mill just built on St. Anthony's Falls, and subsequently was superintendent of the syndicate of lumber 
mills in Minneapolis. Jerry Gardner, another brother-in-law, ran the mill, and the shingle mill also, for quite a while.

The most common way before 1856 was to saw on shares, taking one-half the lumber for the sawing. There was little money in the country, and it was the best that could be done. It was in the days of barter, and the mill's share of the lumber, to amount to anything whatever, had to be drawn first from the boardway, "stuck up" in piles and seasoned, then hauled to market, wherever any could be found. There was no regular market, so it had to be peddled around and swapped off for merchandise and property of any and all kinds.

This lumber drawing was one of the irregular employments that helped us to improve each shining hour, and many hours that did not shine. John had much more of this hauling to do than I, for the reason that he could either do it better or preferred to do it, and when father ran the mill he was oftener drafted for service there. He was older, liked it better and could do it better.

About 1849 a shingle mill was attached to the sawmill, fitted with the latest machinery, but it never made many shingles. There was really no demand for sawed hemlock shingles; besides, they were in close, uncompromising competition with the shaved spruce shingles of the great shingle market of Redfield, where the timber cost nothing and where every house in the town was a shingle factory. Their shingles were called "Redfield legal tender." The town produced nothing else to sell, and it was shingles or nothing with their creditors and all who dealt with them.

Tending sawmill was really a responsible job, and fast lifted the boy into a man. The logs had to be rolled in on the logway and onto the carriage with the cant-hook, and, when slabbed, 
turned and set by hand. All the lumber and slabs, heavy or light, had to be carried out of the mill, also by hand. In early days the slabs were mostly given away, wasted, or floated down the creek; but later they were cut into stove-wood and long wood for boiling sap. Cutting ice when the mill was frozen up, fighting anchor ice, repairing the ditch when it broke and washed out, cleaning the flume and tail-race, were incidents of the work.

Sawing all night was hard, cold work, and full of danger which we then but slightly realized. Occasionally the saw would "run" - that is, bind, heat and get off the line, cutting lumber thick at one end and thin at the other. The crank-wrist or piston-rods would heat, the binder get loose, and the crankshaft jump and pound, and the log would get away from the old dogs and jump up and down as if it were going through the floor, or, in "gigging back," the log would be pulled off the headblock. Worse than all these, the sawyer sometimes got careless and sleepy and "sawed the dog." This was great damage and an utter disgrace. Then the saw had to go to George Ripley's and be "gummed" - that is, new teeth must be cut, filed and reset, as the old ones were battered down and knocked off by its unsuccessful contest with the dog.

Father was very handy in the use of tools and did much of his own repairing; but he had to have a millwright at every radical change or rebuilding. It was quite a pleasure to him to overhaul and improve the mill, and many a good dollar from the farm went into it and stayed there.

The sawmill, being located at the crossing of two principal roads, largely took the place of the country corner store. It made a convenient meeting and lounging place for men and boys, out of reach of the critical eyes and ears of the women - about the only one there was in the neighborhood - and there they 
often met in large and small groups, apparently by accident, to exchange news and gossip. No one of the neighbors' boys ever passed, when anything was doing at the mill, without dropping in, and with the men it was about the same.

When putting in the big breast wheel we had working for us an Englishman by the name of Allen. The wheel had been set and a little water tried on it by letting it run over and across some unfastened planks from the end of the barrel or trunk to the wheel, the regular flume not yet having been built. We boys used to play in this big wheel, turning it as squirrels turn the wheel of a cage. The day of William Barton's funeral all our people were in attendance except us boys and Allen. Another boy, William Gardner, came along, and John and he got into the big wheel and started turning it. There was no water coming through the trunk, the head-gate at the ditch being shut down. Allen went to the head-gate, intending to hoist it just a little and let on water enough to give the boys a scare and then shut it off. To his horror the gate slipped out of the guides and was partly sucked into the mouth of the trunk. The trunk at once filled with water, which rushed down through it and struck the wheel with a jar that shook the whole mill. The wheel, which they were already moving, inmediately started up faster, but not as fast as I expected to see it. John and Gardner were thunderstruck, hardly knowing what had happened, yet realized that their position meant death unless they were immediately released therefrom.

Gardner said nothing, but John screamed like mad, "Shut off that water! Shut off that water! For God's sake, shut off that water!" By sharp running they could keep on their feet in the bottom of the wheel, and thereby keep from being thrown and rolled and tumbled to death. They could not get out between 
the fast-moving arms, which ran close to the abutment on one side and some timbers on the other. The water came up in the bottom of the wheel and made their running more and more difficult.

I took it all in in a second. Allen was up at the ditch, whiter than a ghost, apparently unable to speak or stir. I clambered up a short post of one of the bents which was to support the flume when built, and on which lay the planks across which the water was shooting against the wheel. I had no sooner got onto this plank platform than the water took me off my feet and slid me against the running wheel. The buckets were so built that they did not catch my feet, and, fortunately for both myself and the boys, there was but little space between the end of the planks and the wheel, or I would have been ground up and gone down under the wheel in a jiffy.

The screams in the wheel continued, although I could not now see the boys. I thought fast, and getting over to the edge of the platform on the bent nearest the wheel, caught hold of and rolled off a big piece of black ash timber which had been laid there to keep the water from spilling off the side. I threw it off as if it had been but a scantling. I then got hold of the outer plank, and lifting, as I thought, a ton or more, moved it along and shoved it around off the bents on which it laid. Then I moved another and another plank in a similar manner, until the hole was opened up wide enough so the rush of water fell down and short of the wheel.

When it stopped the boys were in a foot or more of water in the bottom of the wheel, completely out of breath and white as death. The back-water in the wheel-pit and my timely efforts had saved them. They came out of their cage too scared and too much exhausted even to abuse the fool Englishman who had so nearly taken their lives "hin fun." 


\section{FIRST MONEY -- TOWN MEETING}

Like most boys, my first money was that saved penny by penny in anticipation of the coming of the circus. It was earned, mostly, as rewards for various kinds of service which might be called special or extra-a sort of non-competitive system of stimulating ambition and thrift, legitimate and fair, but not calculated to develop unholy avarice. One source of my income was to be the first to discover and report the advent of a newborn calf, for which the reward was one cent. This meant being the first up and at the barn or in the pasture.

From this source I secured twenty cents with which to attend my first circus. It was the old Dan Rice circus, then new on the road - twenty-five cents admission; boys under ten years of age, half price. I was almost too big, but got in and had enough left to buy boiled eggs and peanuts. It was not a menagerie and moral show, but just a plain circus, and there has never been another circus equal to it. No one ever said such funny things as that old clown, and no one ever sang "Jordan is a hard road to travel," or

"I'll never kiss my love again behind the kitchen door,

I'll never squeeze her darling little fingers any more Where has Rosanna gone?"

as did Dan Rice.

One spring, when I was about twelve years old, father gave me a half-acre of half-plowed, tough, cradle-knoll ground above the old orchard to cultivate as my own. It was very late in the season, but, after much anxious labor, I succeeded in securing twenty-four bushels of small potatoes. The next spring they were high in price, and a whining old hypocrite who wouldn't use the hoe, but was very unctious in prayer and earnest in exhorta- 
tion and admonition of common sinners, himself apparently too good to live in this wicked world, bought my whole crop at fifty cents a bushel, and never paid me a cent. I felt badly over the loss, as I had planned many ways in which to use a part of my little fortune, intending to save the bulk. But it was a good lesson, learned young, worth more to me than many bushels of small potatoes, and I have never since been "done up" by overconfidence in the pious professions of pretenders, who try to make their religion or alleged honesty a part of the trade.

My next venture was trapping for minks. Their hides were not then so valuable as to cause their extermination, and, by working early and late, running up and down the creek to my traps, I succeeded one fall in getting twenty-one. Most of them were caught too early and they were not prime skins, but brought, on an average, three shillings each. I was more fortunate in my sale this time, the purchaser being one of the world's people, a young man named Lane Baker, now a prominent clergyman, who expected to pay in nothing but cash. When he took those twenty-one black little hides off the stretching shingles and counted me down seven dollars and eighty-seven cents in silver of all denominations, I felt that I was pretty independent - at least free from any immediate danger of poverty.

It was a great sensation to be rich, and I enjoyed it as keenly as an old miser. I counted the money over a dozen times, and it never came out twice alike. Then, carefully depositing it in the old pewter teapot on the top back shelf in the pantry, with the half-pint of pennies I had accumulated from other sources, I retired to dream of the great financial operations which I had partly outlined for the future. I should go into the fur business that was settled. Astor was a fur trader as well as myself, but he had only Indians to stack up against, while I might expect 
the sharpest competition of white men. The Wilcox boys and some others were already aware of the great chances in minks, and their traps lined the creek from the State Road to the old milldam. To make it short, the prices went up, competition among trappers became fierce, and the minks were soon exterminated. This left me stranded with my "plant," consisting of twelve or fifteen old box traps, which I never took the pains to collect. My first accumulation of wealth, this teapot of money, got away from me gradually, but carried me through many a pinch and panic which struck other boys hard.

Town meeting, or general election, was always a great event in the country, and everybody attended and stayed nearly all day, and, such as could, till after the count. There was no Australian ballot or booth system then. Partisans worked hard for the success of their candidates. Any doubtful voter was first "horse-shedded" by both sides, then pulled and hauled by one party or the other, votes put in his hand, pushed up to the box and pulled away by some one else, until his vote was finally deposited.

It was, necessarily, a noisy, disorderly crowd, as whiskey was sold in the barroom below, while the board sat in the ballroom above, and the electors buzzed and fumed and foamed at the mouth, and talked loud, long and earnestly, each feeling that the salvation of his party and the interest of the country rested upon his shoulders.

Wrestling, jumping and other games, to establish their physical strength and personal superiority, were also common at town meeting. It gave the occasion great importance and made it more interesting than elections of the present time.

Father was seldom a town office-holder, and never sought 
office. He would not buy votes with either money or whiskey. He was an abolitionist, and the town was a pro-slavery one; consequently he was unavailable as a candidate. Notwithstanding this, he was for quite a while poormaster of the town, for which office he was considered to be specially adapted, as he well knew who among the applicants for relief were meritorious and entitled to help. The poor expenses of the town were very light, and few families required or got any relief. Sickness or starvation were about the only grounds therefor.

There were in the southeast part of the town some people known as "Millerites," who were looking for the end of the world at given times. Some of these were so certain one fall that the end was coming that they failed to dig their potatoes. The world did not end as advertised, and along in the dead of the winter the head of one of these families came to father as poormaster to help him out, showing that he had no work and no food in the house for his family, who were on the verge of starvation. Instead of the help he expected, he got one of the liveliest lectures on the "Sinfulness of Sin" and the "Foolishness of the Darned Fool" that I ever heard. After he was gone, mother asked father if he proposed to let the woman and children suffer on account of the man's foolishness. He said, "It would do them all good to fast and pray over night," and that he would go up the next day and look into the matter.

In the town was a man by the name of Philander Smith. He was the wealthiest man in town, and was also a man of fair education, high standing and influence - a man to whom neighbors less successful in the affairs of the world went for advice; in short, he was looked up to by the townspeople as an oracle, and what he said "went" in matters of law or business. A shiftless fellow, whose reputation was way off for either habits 
of industry or morals, applied to father for town help. He gave him a sharp cross-questioning as to his summer and fall work, asking where the proceeds thereof had gone. The questions embarrassed the man, as there was neither work nor its proceeds to be accounted for. Turning on the man, he sharply told him that if he would not work in the summer he need not expect the town to feed him in the winter. The fellow whiningly mentioned the fact that his wife ought not to suffer for his fault. This riled father still worse, and turning upon him he said, "Your wife! that woman you live with is not your wife, sir." This the man denied. Then he was asked when he was married, which he answered promptly. The next question was, "What minister or justice married you?" This did not seem to embarrass him the slightest, but his prompt answer was, "We were not married by a minister or a justice, but Philander Smith gave us a permit."

\section{9}

\section{THE GULFS}

The gulfs of Lorraine are and always have been an interesting feature of the town and this part of the State.

A large part of the town is underlaid with a most peculiar rock formation, not known to exist to the same extent elsewhere, which is called "Lorraine shale," because here its development and distinguishing features are most marked of any place in the known world. The streams crossing this shale rock have worn down, causing deep gulfs of a most remarkable and interesting character. Their perpendicular banks show clean-cut, regular, perpendicular courses, from two or three inches to three or four feet wide, divided by seams so fine and close that they can 
hardly be detected in some places. The layers of stone parailel to the surface of the earth are of all thicknesses, from a quarter of an inch to five or six inches, and of different degrees of hardness. Both the perpendicular and horizontal courses are very irregular in thickness and width, but otherwise as regular, square and perfect as if formed by the most accurate mathematical tools.

The seams up and down, and the courses which they divide, are as plumb as if made with reference to absolute accuracy in that respect, and everything about them looks as if laid and worked by the square and plumb. When, through the action of frost or from any cause, a section falls from these high walls, the hole left is rectangular and regular, and the sides and back thereof smooth and true as though cut and polished by a marblecutter. A section only a few inches wide and deep, but perfectly true and rectangular for fifty or a hundred feet, will loosen and fall, leaving it with the appearance of having been carefully cut out, removed and finished up in that shape.

These peculiarities, so different from anything elsewhere found, geologists are unable to account for - at least they have never agreed upon any theory which they dare endorse. They tell us that this Lorraine shale was formed in the Silurian period, but can give no reason whatever for this, one of the most marvelous exhibitions of God's masonry yet found on this old globe. Ages of unceasing effort in trying to fathom the great mysteries of creation, so far has accomplished nothing. The geologist, with all his scientific attainments, gives us no more light than the answer of the child _. "God made it so."

These gulfs are nearly parallel and run east and west, dividing the town into sections, and keep the people of their respective localities from very close acquaintance, as bridging them is 
too expensive for the benefits expected. Their depths vary at different points, two hundred and fifty feet being the deepest.

They are wild places, but filled with beautiful scenery, quite accessible if one has time to go down into and through them. The "Huddle" Gulf, into which the Fox Gulf leads, was early bridged at the Cal. Totman place, but was until very recently a hard, dangerous crossing, and, although it was much the nearest way to Adams, the people in our section preferred to go around by the Little or Fox Gulf, or some other safer road.

The North Gulf, called the " Big Gulf," was bridged at John Gifford's, but was avoided for the same reasons. Even the Little Gulf crossing, near Fox's, was shunned in early days, being very steep on both sides. Each gulf had but one bridge, and all had their dangers and difficulties, causing many accidents. Henry Wright, of Greenboro, because of a broken neckyoke, ran off the Gifford Gulf with a load of shingles and went down a partly sloping, partly perpendicular bank ninety feet high; landing in the top of a tree saved him and his horses from certain death. A brother-in-law, Bernice Doane, once had a horse crowded off the end of the Little Gulf bridge; it dropped through the harness to the creek, twenty feet below, leaving its mate on the bridge with the sleigh, full of people, just balanced, one runner on the bridge and the other three-quarters off. Father once had his harness give way on the steepest part of the Totman Gulf; this let the democrat wagon, in which he and mother were riding, upon old Dick's heels. Any other horse than old Dick would have dashed them over the bank into the gorge, a hundred feet below. There were plenty of accidents, but I remember no fatalities.

These deep gulfs made homes and hiding places for wild animals of all kinds, and if one was started in any other part of 
the town or adjacent country, it always led off for one of the gulfs. The fear of what might be there made them pokerish places to cross nights, or even for a boy to fish alone in the daytime.

The crossings have been graded down and bridged up until very different and much less dangerous, yet they are among the memories of the old home which made a lasting impression, and claim recognition here.

\section{so so so}

\section{THE STATE ROAD}

The war of I8I2-I4 showed the need of a good road from Fort Stanwix to Sacketts Harbor and the northern frontier, and the old road built by the first settlers was improved and rebuilt by the State so as to facilitate the movement of troops and munitions of war to the frontier. Since that time it has been known as the State Road, and for many years was the principal road from the Black River country to Albany and New York.

Its building and use did much to settle and develop the town early, placing its settlers on the best possible basis as to markets and communication with the outside world. It was not only famous on account of its military history, but also its record as a stage route of great prominence.

One of my first excursions from home to see the world was when I went over the Fox Gulf to the State Road, near Lem Hunt's Tavern, to see the stage go by. This old tavern stood well back from the road at the Corners, and there, in later years, John Hancock, John Robinson and Levi Pitkin successively lived. There were two regular stages a day, with extras when required. 
A large part of the public travel which now goes over the Rome and Watertown railroad, and part of that of the Black River road, was accommodated by these stages. They were usually crowded inside and out, with twelve or fifteen passengers each, with trunks strapped on behind and on top. Relays of horses were furnished at least every ten miles, and good time was made. The horses were seldom allowed to walk, even up the steepest hills.

There was a tavern of more or less pretensions nearly every two or three miles. For instance, leaving Adams, in the town of Lorraine was the Deacon Brown Tavern, at Allendale; the John Alger House and the Chester Gillman House, at the "Huddle;" Lem Hunt's Tavern, at the Corners; the old Risley House, on the Abram Calkins Corners; the Hesketh Place and the Dick Hart House, near the Boylston line - all taverns of standing and reputation - within seven or eight miles.

As the travel increased, many people who were not pretending to keep a regular public house accommodated travelers and teamsters. The travel by private conveyance by far exceeded that by stage, and this old State Road was a busy thoroughfare from I 8 I $_{4}$ to I 850 . Uncle Dan Beals once told me that he had slept and fed seventy-five people in one night at the old log tavern in the middle of the woods, now Greenboro. They did not have spring mattresses nor fine furnishings, but covered the floors of the whole house, travelers using their own blankets and buffalo-robes for bedding.

In addition to stage passengers and general travelers, there was a stream of teamsters hauling goods both ways, as the freight to and from Rome, Utica, Albany and New York was taken over this road.

As often as possible I went to the State Road to see the I 69 
stage come and go. It was a great sight to watch it come up the road from the "Huddle," with its four horses on a sharp jump, with a deck-load of laughing, joking passengers, the driver sitting straight as a cob on his seat, holding the four lines in his gloved hands and occasionally swinging and cracking a long whip over the heads of the leaders, or with the long lash entangling a chicken or touching up a saucy dog beside the road. As they came opposite the old distillery near the corner, the team was put to a sharp gallop and whirled up to the tavern door with a splurge and hurrah that brought things up standing. The passengers jumped out and ranged up to the bar in a jiffy, suaged their thirst, climbed aboard and were off again like a shot for the next tavern. They did not always stop at every house; the passengers or their appetites controlled that. A load that would take their sap at every tavern from Watertown to Rome was said not to be uncommon in those times, when tippling and rum drinking was thought to be the right thing by almost everybody.

I was, with several other good, little boys in our school, expecting some day to be president of the United States, for our teacher, Aunt Lucinda Barton, had assured us that our chances were good; but I would have gladly swapped my chance for president for a dead certainty that I would some day be a stage-driver.

About 1848 the building of the Rome and Watertown railroad was begun. Farmers all along the line and in adjoining towns were solicited to take stock, and many did so. It was completed as far as Adams July 4, I85I, and a great opening excursion was advertised. Father was a stockholder to the extent of five hundred dollars. There were no hideous trusts then, and holding a nice, five-hundred-dollar block of railroad stock gave him financial standing and made him feel good; so he took us on this excursion, which was to run from Adams to Richland, about eighteen miles. 
We got up early and reached Adams an hour or two ahead of time. The puffing engine, with three small, yellow cars, stood on the track just north of the creek, hooting and screeching. I had never before seen a locomotive or car, and I well remember the sensation of awe and wonder with which I looked them over, at first making sure that I was not too near, for I was really afraid of the engine, if not of the cars. We got aboard early, fearing we would be left, and started on our trip about ten o'clock, moving off at what I then thought to be with dangerous rapidity, and reached Richland about noon. We stayed a little while at Richland, and returned to Adams under the same reckless speed at three o'clock in the afternoon. To know how fast we were going I counted the fence-posts, which were seven or eight feet apart. I found that I was compelled to suspend my count every few rods by reason of having got ahead of the train.

To me it was an experience and a day to be remembered. Young as I was, I began to dream of something faster and stronger than old Dick, our favorite horse, and of places and things far away outside of Lorraine-even beyond Rome and Utica. Neither was I, the small boy, the only one who had his eyes opened and saw new light through the changes speedily wrought by the new steam road.

The road was soon finished to Watertown, and the old stage route, lined with thrifty, busy people, was forever gone. The long chain of comfortable, money-making, old taverns from Watertown to Rome were never again to see the jolly and familiar faces of their long-time guests. The uses and activities of the old State Road had departed, never to return, and with them went the flattering hopes and prospects of many an old Lorrainer, and my youthful ambition to be a stage-driver. 


\section{THE OLD RED HOUSE}

After the lapse of the log-house period, our folks built what they always spoke of as the "new house," even after it was sixty years old. The cellar wall was started in July, I823, and the chimneys in the north and south ends of the main part were built in 1825 . The family moved to the new house in I824, before it was completed. The front part was occupied for a few years as a store, and while so used the lower part was not finished up.

It was built in the fashion of those days, with a long, twostory front, with piazza across the whole length, a wide hall running through the middle, and with a long, one-and-a-halfstory wing, perpendicular to the main part, for kitchen, woodshed, well and storeroom. At first it had only chimneys and fire-places for heating and cooking purposes. There was a big chamber on each side of the hall upstairs, in each of which three double beds were frequently set up and in use. These sleeping-rooms were large, airy and well lighted - all right in the summer, but cold and uncomfortable in the winter. Their hard, bare, ash floors were like ice in the cold, frosty weather, and unless a piece of old carpet or a rug was in front of your bed, you would shudder and shiver from the minute you got out of bed until your teeth rattled. With the thermometer twenty to forty degrees below zero, nothing saved you but the big feather-beds, in which you could cuddle down between the flannel sheets and cover up your head with all the blankets you could endure. Each room was plenty large enough to make two good bedrooms, and one of them was so divided later.

There was but one closet or clothes-press in the house, and that was a big, dark one off the south room. It was always 


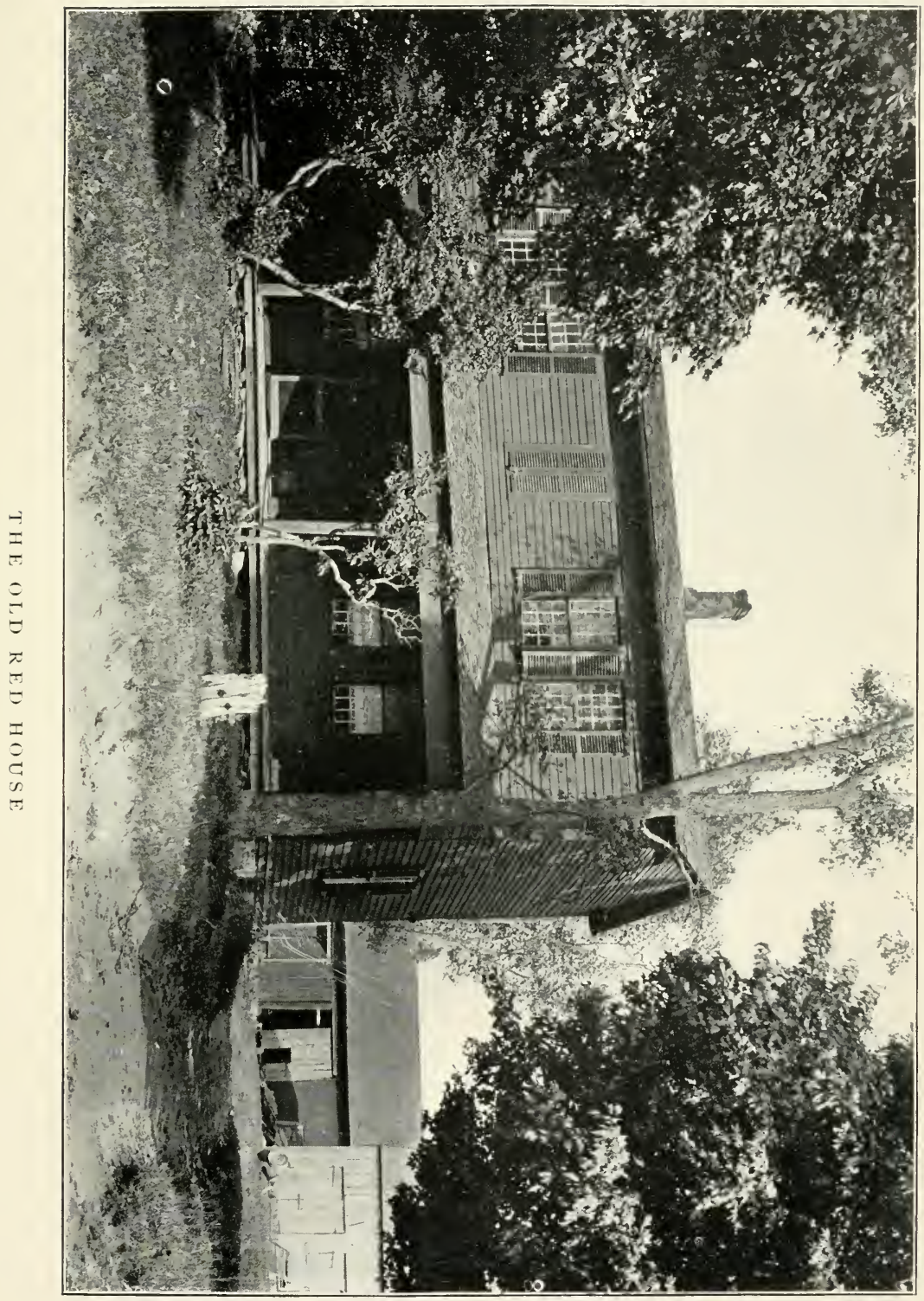




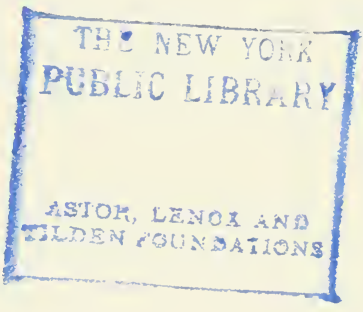


jammed full with our Sunday clothes, besides every other kind of duffle kept in the house. Instead of regular closets there were movable wardrobes, big chests in which to store bedding and other supplies, and lots of nails driven into the wall on which to hang clothes - a first-rate arrangement, because you could so easily find the things which you wanted that were hanging on the wall. The kitchen had a bedroom adjoining, with a row of nails clear around it.

The large, old-fashioned pantry, with long, broad shelves from near the floor to the ceiling, was called the "buttery." In addition to a pantry it was a small drug store. We were six miles from a pharmacy, and a supply of the principal drugs and simple remedies was necessary. A well-room and storeroom, also fitted up as a milk-room, was taken from the west side of the woodshed.

Overhead, in the wing, was the "dark chamber," a kind of ghostly, Bluebeard place where we stored butternuts, seed-corn, popcorn, vinegar, dry herbs, and everything else that had no other place. Sometimes in bitter cold weather, when going to bed in the unheated chambers was too disagreeable, we boys slept in this dark chamber on an old-fashioned bed called a "cricket," something after the style of a hammock, being simply a piece of canvas stretched on a folding frame. When we slept there we relied upon being called, otherwise we might sleep until noon in the pitchy darkness. The call was made by some one rapping on the kitchen stovepipe, which ran through and warmed the room.

After the use of the fire-place was discontinued, one stove fire was generally considered sufficient for both cooking and heating purposes. Wood was not scarce or expensive, but it had to be cut and fitted for the stove, a "Northern Farmer" 
elevated oven, which consumed large quantities of it. However, when the girls took a notion or when we had company, an extra fire was kept in the south room or parlor, and on state occasions, like Thanksgiving or the arrival of very select company, in both. This old elevated-oven stove was a great heater and wonderfully comfortable to put your wet feet and legs under in slushy weather. Back and above it were the poles upon which were slung the long strings of apples and pumpkins to dry.

The south room was the one most used as a sitting-room. The little, square stove with crooked legs, in this room, was to me a source of great annoyance, for, while consuming great quantities of wood, it would not take a stick over ten inches long, and very small at that; but around it we young folks and our company spent many a happy evening, playing games, singing songs, telling stories, guessing riddles, cracking butternuts, eating popcorn and apples, or doing anything else that pleased us, free from the supervision of the old people.

Bernice Doane gave it the name of the "sparking stove." He certainly had a right to name it, as he was the first to use it in that capacity. It made untold trouble for the boys who had to saw, split and bring in its little, short blocks. In those times I hated the harmless little thing on account of the trouble it made me through its diminutive size, but it went through many a hard campaign, outlasting all other old, family stoves, and came out victorious and sound, and is now on the retired list, carefully stored in my garret, a souvenir of old times.

The kitchen was the most pleasant and comfortable room in the house, and it was always warm and light. It was the universal assembly room, and the reception room into which neighbors came who made a casual call. It would not have 
been thought sociable or friendly to seat any of our near neighbors or familiar friends who were making an informal call in any other room than this. It was the room most used and useful, and, before the fire-place was taken out, was really a cheerful place where all could gather and have plenty of room.

When her household work was over, mother was always found here, in her wooden rocker in the corner by the old-fashioned wooden clock, rapidly plying her knitting needles, which she called "resting." Father's place was the chimney corner, so his candle could set on the mantle while he read his book or paper, always reading aloud unless others were doing something that would be interrupted. He was a good reader and it was a pleasure to hear him. His reading of "Uncle Tom's Cabin," first published in the National Era, his favorite abolition paper, was a treat for any one.

Those of us who wanted to read or study evenings gathered around the big table, where there burned a candle, or, if three or four of us, perhaps two, or a big whale-oil or camphene lamp. If no one was using the light it was put out. Lights were not burned except there was particular use for them. There was plenty to use, nothing to waste.

The big fire-place was a feature of the kitchen not easily forgotten. It was kept in use many years after the adoption of stoves. The stove was more economical of fuel, but could not give the cheer and comfort of the fire-place. I still remember the fire-place cooking. Big dinner pots, blubbering and walloping, hung on the swinging crane, with the old, black teakettle; the open, tin bake-oven stood on its hind legs before the huge fire, with the biscuit tins inclined toward the coals, and glowed and glared, while the long-legged spider or skillet sputtered and sizzled over a bed of coals close by the crane jamb. Fire-place 
cooking was lively business and required constant watching and attention. Just to the right of the fire-place was the mouth or door of the great brick oven, filled with bread, pies, cakes, apples, and everything else that was best cooked by its steady, even heat. Nothing has ever excelled the old brick oven as a perfect baker, and when custom required that pie be served with every first-class meal, they were almost indispensable, on account of their capacity as well as the superiority of the food they turned out.

The culinary reputation of the New England housewife depended largely on her pies, and a pie more than anything else depends on the baking. It was no trouble to fill in a dozen or more large, square pie-tins at one time, and when the pies were done, the same heating would bake pork and beans, corn bread, or sweet apples, by leaving them in over night - this was the only correct thing for "rye-and-Indian" or straight corn bread. I was always willing to get oven wood - that meant pie, baked apples and cheese without stint, between meals or any other time when wanted. Mother approved of children eating whenever they were hungry, and for the first fifteen years of my life I was hungry most of the time.

In 1840 the big chimneys were taken out of the upright, but the kitchen chimney and the brick oven remained some twenty years or more longer. The house has been changed inside and made more convenient in some respects, but the general features remain yet. The first coat of Venetian red, after being covered with several coats of brown, is just coming out again, almost as good as new.

Like other people's wells, our deep, cold well was thought to be the best in the world. The water was very palatable and probably pure, but it was hard, lime water, which we enjoyed because we were used to it. 


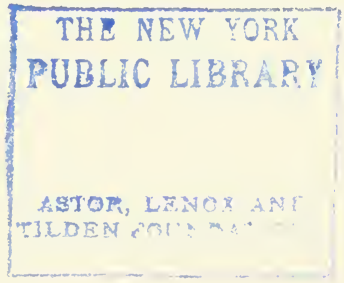




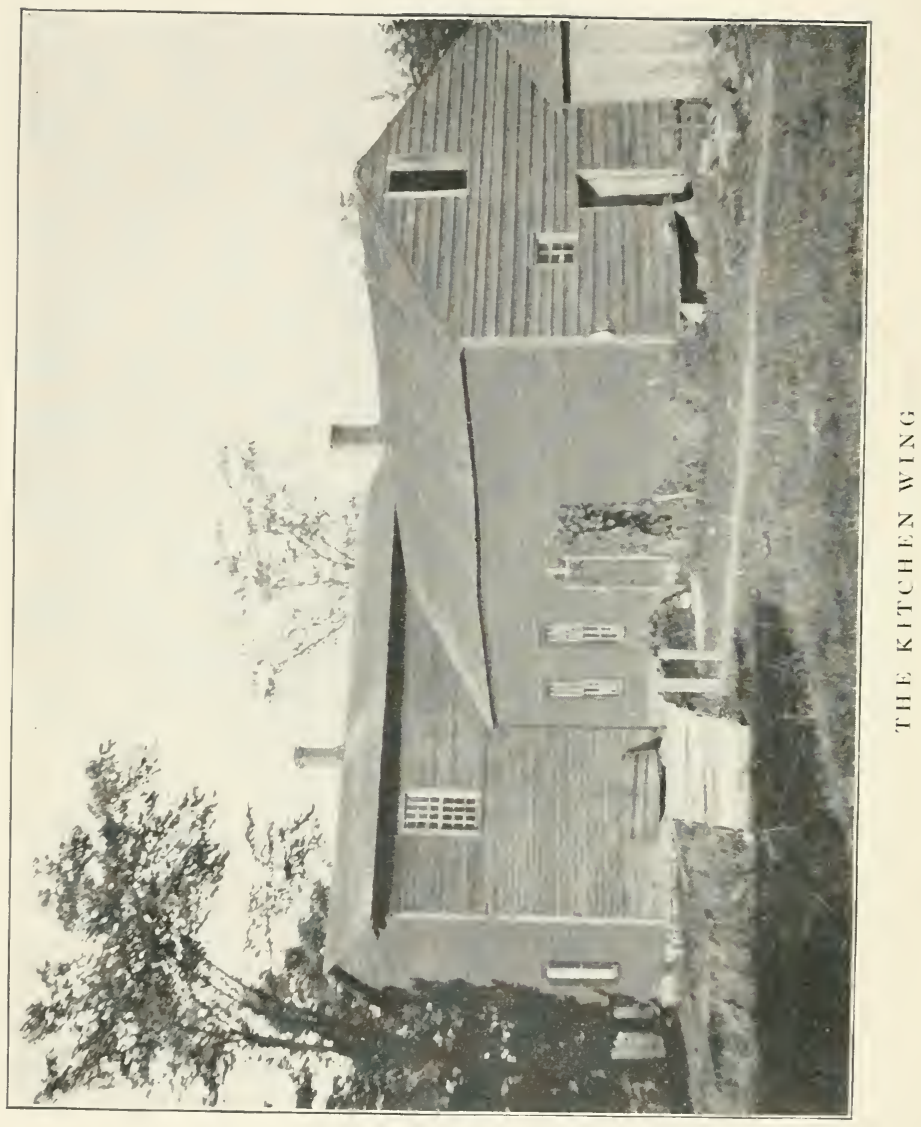


The long, cool piazza, with morning-glories or trumpet-vines, was a delightful spot for a summer day or an evening rest, and when stretched out thereon with a blanket and a book, one could take solid comfort. When old enough or good enough to be excused from going to church, that was my favorite Sunday summer resort. The opportunities for lounging or rest were limited by the exigencies of work, and if not the more important duties, there always was some minor task which must be done, so that week-day idleness was unknown.

Although the country and location was a healthful one, we had our share of sickness. The family was large and all had in due time most of the common ailments, like scarlet fever, measles, chicken-pox, whooping cough and mumps. Old Dr. Webb, who lived at Adams, was the family physician. $\mathrm{He}$ generally traveled on horseback on an old sorrel horse, or in his old-fashioned, thoroughbrace sulky, and carried a big pair of black saddle-bags filled with bottles of all the most bitter, nasty medicines then known. He was an allopath, who gave doses for a horse, was always joking, and invariably accused his patients of playing sick.

When he drove up and threw down the lines or handed over the bridle, his greeting was, "John, put old Tom in the barn and give him a bushel of oats;" and, going in by the kitchen door, he would call out to mother, or whoever was there, "I am starved to death. Got any nutcakes, pie and cheese?" After eating his lunch he would see the patient, not before, unless in some remarkable emergency. He was a genial old man, who blistered, bled and physicked after the old style, and I often wondered how so many of us got by him and lived to grow up.

There was always a large stock of medicinal roots and herbs in the house, with which ordinary ailments were treated, and 
their liberal and intelligent use may have been our salvation. Being remote from doctors resulted in the exercise of individual intelligence and good judgment as to the care and treatment of disease. Mother and all my sisters were well posted in the use and effects of ordinary remedies and in the nursing and care of the sick. I have the conceit to-day to think my sister Mary, without a diploma or any technical schooling, a better doctor than three-quarters of the regular graduates.

Grandmother Pitkin, who was a famous midwife and skillful nurse, was a near neighbor and frequent visitor. She was eccentric, but kind and good. She hated liars, hypocrites and lazy folks, and let them know it. Possessed of a genuine kind heart and a fine, sympathetic nature, although sometimes rough in expression, she was always ready to go where there was sickness and distress, without other reward than the satisfaction of doing good. Her life history was one of continuous charity, and the earnest, honest work of the good Samaritan.

Aunt Betsey Harmon and Aunt Clarissa Wise were both skillful nurses. They were untiring, courageous, discreet and sympathetic women, with hearts made tender and kind by the trials of their early orphan life, and their advent in a sick-room was a comfort and cheer to the most despondent. They never failed to come to our relief in case of any really serious trouble. Each had a large family of her own, but never lacked time or disposition to help others in distress.

Mother's terrible illness and affliction at the time of my birth, and the sisterly affection and devotion of Aunt Betsey and Aunt Clarissa, and the kindness of neighbors in helping care for and nurse her at that time, were often recited to me by my older sisters. Her subsequent serious and very long illness, from which she never fully recovered, I clearly remember. The death of 
brother Gilbert's wife in the spring of 1845 , and his departure for the West, followed by the unexpected news of his own death in the early fall of the same year, I also remember.

The sorrowful ending of the useful life of Aunt Clarissa Wise affected me deeply, as it did all who knew her. The early death of Uncle Alexander Waugh, and the untimely death of brotherin-law Henry E. Allen, who had been my teacher for one term and who was a great favorite with all, were among the things which fastened themselves deeply in my mind.

I have referred to a few of the leading affairs which occupied my time and attention as a boy; but in going over and reviewing these, hundreds of other incidents which were to me in their time of sufficient interest to make a lasting impression, come back with vivid clearness, but time and space will not allow any lengthy mention thereof.

The memories of the old house itself bring with them recollections of things in its particular vicinity, like the woodyard, with its great pile of firewood in all stages of preparation, always a place where work was needed; the front yard, with its gravel walk, bordered by long flower-beds of violets, marigolds, pinks, peonies, lilies and hollyhocks, and surrounded by rose, lilac and flowering bushes of all kinds; the adjacent apple orchard, in which every tree was a familiar friend and had its own history and meaning; the garden, with its perennial beds of asparagus, tansy and sage, with wormwood and wild celery bushes in the fence-corners, and long beds of all kinds of kitchen vegetables, always calling for the man or boy with the hoe; the famous old cherry tree that hung over the great rock; the long corn-crib filled with yellow ears, once used as a great coop during the spring of the famous pigeon flight; the rocky, side- 
hill milking-yard, with the big rock near the plum tree, on which old Neuch always stood to be milked; the long rows of swallows' nests under the eaves of the barns and sheds; the horse-barn, with its wide-open doors and its well-known occupants - blind Dick, the reliable veteran; balky Bill, the terror; runaway Doll, the fox; colicky Prince, with his innumerable bottles of medicine, and knee-sprung Dick, the reminder of a clerical horse deal; the little, red, "bear dog," Getty, who would sit in the middle of the dooryard and bark all night at the man in the moon; the ugly, gray watchdog, Tiger, who challenged every tramp or suspicious looking character that passed or stirred at night, and who finally made the mistake of tackling the presiding elder as a suspect and was only called off by a club with which John ended his over-zealous life; the useless, yellow dog, Rover, who had no standing or character whatever until, like Tray, he fell into bad company and, on suspicion, was condemned as a sheep thief; the ditch and the mill-pond where we went to swim, and the creek with its bed of huge boulders, where it came splashing down between the rocks into the deep trout pool under the bridge; the old sawmill and the mill-yard, with its high piles of logs and lumber, among which the school-children played; the old, weather-beaten school-house on the corner, cut and carved by the knives of two generations, with its pleasant memories of teachers and schoolmates; with the burying-ground beyond, so venerable and solemn, where peacefully rest our ancestors, beside the other pioneers who here labored to subdue the forests and found homes, under their moss-covered tablets, which tell the story of a century. These and many other things in retrospect I see around the old homestead, all as clearly as when they first crossed my vision.

This old red house has withstood the winds and rains of sum- 
mer and the frosts and snows of winter for fourscore years. It has seen generations born and die; it has seen families come and go; it has had for many years the care of its founders, and for a long time the neglect of indifferent tenants and strangers; it has stood to see those from under its roof scattered throughout the wide land, and most of them go to "dwell in a house not made with hands." Yet it still stands to recall the memories of the happy home which so long existed within its walls. It tells me of father, mother, brothers and sisters, neighbors and old-time friends, of each and all, and takes me back to the joyous days of childhood and youth, when I longed for a more speedy flight of time that I might sooner reach the realm of manhood, little dreaming the day would so soon come that I would wish to retard the swift-passing hours which so rapidly bear us forward. It brings back the ambitions, hopes, fears and fancies of youth, and as memory rapidly shifts the retrospective view, I again go through the many, many, busy, shifting scenes of a happy childhood and youth spent in this old red house - HOME. 












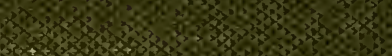

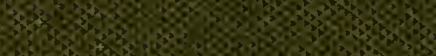

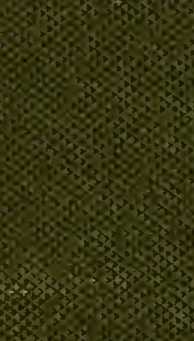

$30,03,35$

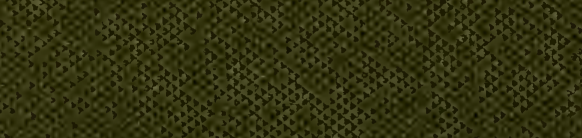

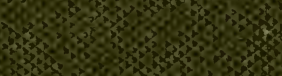

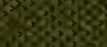

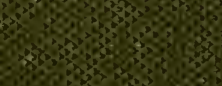

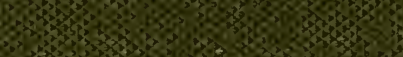

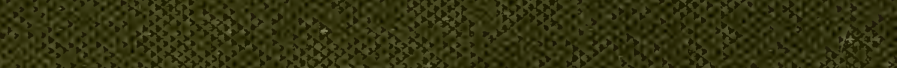

3.

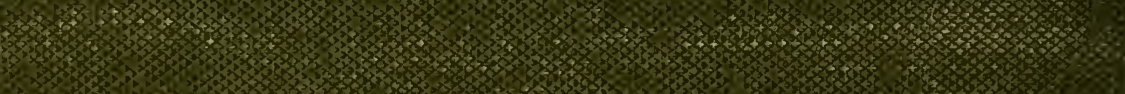

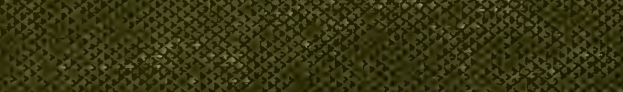

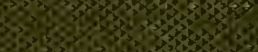

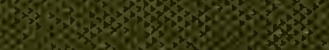

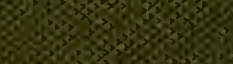

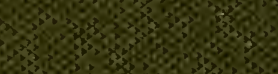

$3,3,35,35$

$86,3,3$,

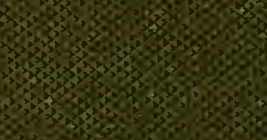

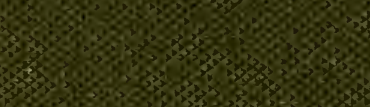

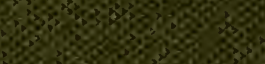

